\title{
ASPECTOS SUBJETIVOS Y OBJETIVOS PARA LA RECONCILIACIÓN EN COLOMBIA
}

\author{
ESTEFANÍA LUNA ESCALANTE
}

UNIVERSIDAD SANTO TOMÁS

FACULTAD DE FILOSOFÍA Y LETRAS

BOGOTÁ

2015 
Aspectos subjetivos y objetivos para la reconciliación en Colombia

Estefanía Luna Escalante

Trabajo de grado para optar al título de Magíster en Filosofía Latinoamericana

Director:

Álvaro Acevedo Gutiérrez

Universidad Santo Tomás

Facultad de Filosofía y Letras

Bogotá D.C.

2015 


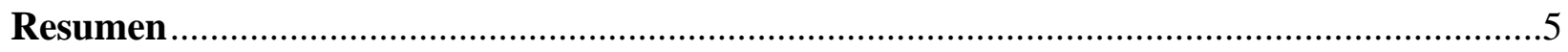

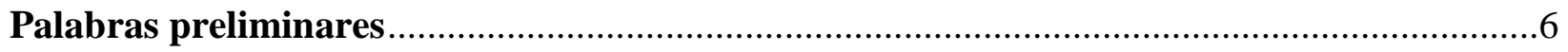

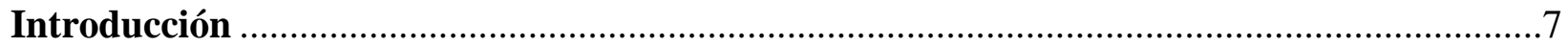

\section{Capítulo I}

\section{UBICACIÓN CONCEPTUAL DEL CONCEPTO DE RECONCILIACIÓN.}

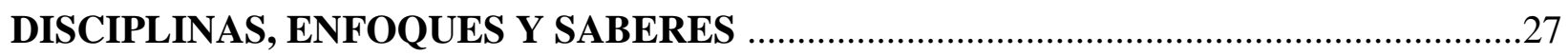

1.1 Elementos fundamentales de la reconciliación en la teología de la Religión Católica:

relaciones entre Dios y el hombre y entre la iglesia y la sociedad......................................29

1.2 Categorías fundamentales para la reconciliación desde la filosofía contemporánea ..........37

1.3 Formas políticas de la reconciliación ..................................................................48

1.4 La justicia transicional como escenario jurídico de la reconciliación...............................55

1.5 La reconciliación desde la mirada de comunidades no occidentales en América Latina ...59

1.6 Hilando propuestas, reconociendo conceptos y sentidos para la reconciliación................63

\section{Capítulo II}

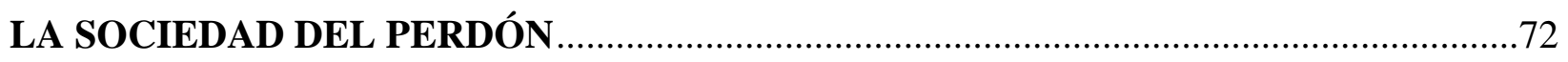

2.1 Miradas y prácticas de memoria y no memoria ….....................................................75

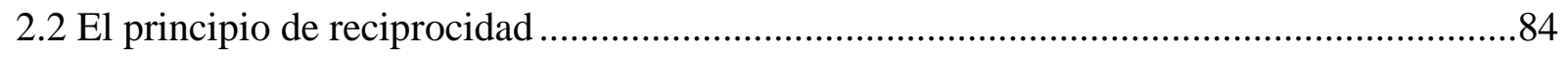

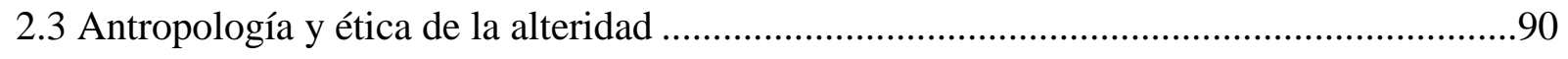

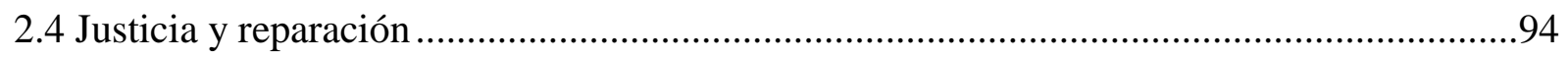

\section{Capítulo III}


3.1 Reflexiones generales sobre el posconflicto en Colombia..........................................107

3.2 Temas y propuestas fundamentales para la reconciliación en Colombia.........................116

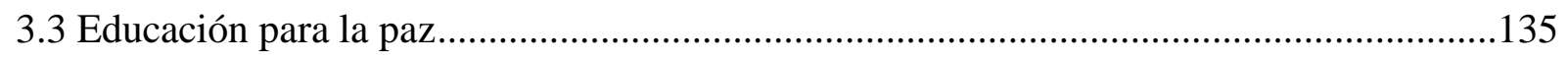

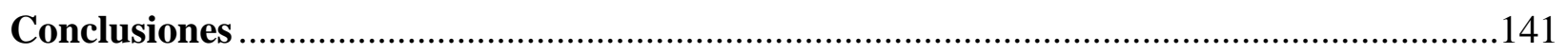

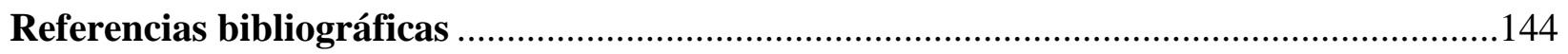

\section{INDICE DE TABLAS}

TABLA 1. El problema de la reconciliación desde las distintas disciplinas y campos de conocimiento 


\section{RESUMEN}

La reconciliación es un concepto polisémico y multidimensional que abarca distintos aspectos del ser humano y de la sociedad, y amerita ser investigado, con el fin de aportar elementos reflexivos para la construcción de un orden social basado en la alteridad, la justicia, la reciprocidad y el bienestar de los ciudadanos, así como en aspectos necesario de la distribución de la riqueza y puntualmente de la tierra. En el contexto actual colombiano, demarcado en el ámbito político nacional, por las negociaciones de paz que se adelantan entre el Gobierno Nacional y la guerrilla de las FARC-EP, la pregunta por las condiciones necesarias para la superación del conflicto armado late y ocupa un lugar protagónico en la esfera pública, y de modo especial, en el ámbito académico. En este sentido, se presenta una propuesta de reflexión en torno al concepto de la reconciliación que se erige a partir de dos dimensiones generales: una subjetiva en la cual se describe la sociedad del perdón como la construcción de una nueva sociedad orientada por el ejercicio de la memoria, la práctica de la ética de la alteridad, la reciprocidad, la justicia y la reparación. Y un segundo aspecto amplio que se sustenta en la premisa de que la reconciliación en Colombia debe asumir de antemano la transformación social estructural de los problemas históricos y originarios del conflicto armado. Todo ello orientado desde la pesquisa del sentido y formas de la reconciliación consideradas por distintas disciplinas y saberes como la teología, la filosofía, la ciencia política, el derecho y la sabiduría indígena.

\section{PALABRAS CLAVE}

Reconciliación, sociedad del perdón, transformación social, conflicto armado colombiano. 


\section{Palabras preliminares}

Desde la sabiduría muisca se propone la tarea del hombre de volver a darle orden al universo, a las palabras, a las acciones. Es volver al origen, un origen de equilibrio, prudencia y bien-estar.

La reconciliación es un valor necesario para lograr una sociedad de posconflicto. El posconflicto como se presenta, reconociendo que la historia del posconflicto significa el aumento general de las actuaciones militares por el control territorial de las zonas en conflicto. Entonces olvidar el desafuero por el dominio de imposición sobre el quehacer y método político como ha sido ejecutado por la oligarquía colombiana; y pensar, asumir una forma política de la comunidad, con un tipo de características. Pensar la política del diálogo, buscar escenarios diferentes de comprensión para asumir otra forma de vida ante la vida misma, que se presenta como condición previa y originaria de la transición, ejercer la liberación social a través del perdón, el trabajo, la justicia, la reparación, la memoria, y el trabajo colectivo, orientados al fin de guerra y el inicio de la paz.

El sentido de pensar la reconciliación surge del reconocimiento de que existe un conflicto armado. El reconocerse en una situación conflictiva de culpas y errores, rencores y dolores, de sufrimiento y desigualdad, genera un pulso como potencia para el cambio. Para desear el cambio. La reconciliación en Colombia es ante todo el anhelo de personas sufridas, paridas en el dolor de la violencia, que respiran violencia, porque de eso está hecho el ambiente. Quienes cerca están de la violencia cruda, de esa socialmente construida, ya sea como ejercitantes o como caminantes, interpelan por un proceso de paz que abra el sentido de la reconciliación, para finalmente vivir bien, vivir en paz. Entonces ante todo la reconciliación es un sentir anhelado de las víctimas del conflicto armado.

Debe entenderse la reconciliación como un estado en construcción que surge de grandes dolores, de juicios severos sobre la historia, de políticas y políticos, de armas y trincheras, de las entrañas de un país que derrama sangre, pero que incesantemente reclama vida, paz, bienestar y justicia social. La filosofía decide en este escrito asumir el reto de avanzar en la construcción reflexiva y activa de nuevos órdenes y sentidos para un nuevo estar, para un nuevo ser, para un nuevo sentir. 


\section{INTRODUCCIÓN}

La reconciliación es un concepto que tradicionalmente ha sido abordado por la teología, o bien por las distintas religiones en especial, por la cristiana, la cual surge precisamente por el acontecimiento de la vida y obra de Jesucristo cimentada en la idea y acto del perdón de los pecados y la reconciliación del hombre con Dios y de los hombres entre sí. Sin embargo, en las últimas décadas, y con el desarrollo de teorías sociales y jurídicas especializadas en el abordaje de los procesos de posconflicto y transición, el tema de la reconciliación ha cobrado especial interés académico, intelectual, social y hasta gubernamental, en la medida en que se ha pretendido, desde distintas instancias, aunar esfuerzos para asumir procesos transicionales, ya sea en el tránsito de una dictadura a un régimen democrático, o bien, de un conflicto armado a un estado de derecho y paz. En este sentido, la reconciliación como concepto político se inscribe en la pregunta de cómo darle tratamiento jurídico, social y administrativo a un proceso transicional.

Para comenzar, se puede referir que en términos generales, la reconciliación supone ante todo un estado de conflicto, o enemistad, o de enfrentamiento, que se manifiesta en una relación de combate, animadversión, y/o hostilidad, que en último término impide la convivencia pacífica, solidaria y civil de los ciudadanos o habitantes de un determinado territorio. Este escenario se constituye con actos de violencia, represión, odio, persecución, crimen, que a su paso van dejando sentimientos de resentimiento, rencor, desesperanza, profundo dolor y desconfianza. Así mismo, las dinámicas conflictivas pueden desembocar en una guerra -de baja, media o alta intensidad-, un conflicto armado interno, entre otros, que por su misma esencia y sentido estratégico, traen como consecuencia el uso desmedido de la fuerza, la violación sistemática de los derechos humanos, la comisión de crímenes de lesa humanidad, la fragmentación del tejido social, la desconfianza y enemistad entre ciudadanos, la generación constante de sufrimientos y memorias del dolor, y la dirección de las fuerzas políticas hacia el desarrollo bélico de la contienda.

Actualmente en Colombia, asistimos a la construcción de un proceso de paz que se debate institucionalmente en las negociaciones entabladas entre el Gobierno del presidente Juan Manuel Santos y la guerrilla de las FARC-EP, en el que se han discutido y acordado algunos puntos 
identificados por las partes como ejes fundamentales de un posible acuerdo final que pondría fin a la confrontación armada entre ambos bandos. Sin embargo, y a pesar de los esfuerzos políticos de dichos actores, la construcción de ese estado de post acuerdo, depende tanto de ellos como del conjunto de la sociedad colombiana y, siendo que la paz es un concepto tan amplio y difuso, defendido a partir de posturas diferentes, se hace preciso que la ciudadanía reflexione y proponga rutas de acción para la construcción de la paz que anhela. Además, teniendo de presente las múltiples y diversas formas de dolor, sufrimiento y rencor que ha producido la guerra en el país, y de cara a la construcción de una paz duradera, sale al paso la cuestión de la reconciliación como una apuesta personal y social que se asuma como tarea política con rasgos morales para la superación del conflicto armado y la posibilitación de un estado de paz y justicia en un proceso transicional y de posconflicto.

Es en este escenario en el que cobra relevancia el pensar y el desear la reconciliación, pues los sujetos enfrentados y sobre todo, las víctimas y la población civil, entienden que existe otra forma de resolver los conflictos y diferencias, y asumen una posición de anhelo profundo e incesante de paz, justicia y orden alternativo al de la guerra. Una vía democrática, política, de encuentro en el acuerdo y el disenso; se trata de la esperanza y el entendimiento de finalizar el horror de la guerra y ponerse a la tarea de construir comunidad desde el diálogo y en los escenarios de la política democrática. A pesar de que los actores en contienda no se limitan a los señalados, los actuales diálogos de paz constituyen un panorama significativo para la pregunta filosófica y política de la reconciliación, asumiendo de antemano que en términos pragmáticos nos referimos a un proceso arduo, complejo y multidimensional que abarca distintas dimensiones de lo humano.

La reconciliación se entiende acá como un proceso socio-político con fuertes rasgos morales encaminado a la reconstrucción de la sociedad en un escenario transicional, que se dinamiza desde la pretensión de la superación de un conflicto social y armado, a partir de la generación y acción de aspectos subjetivos y objetivos que en determinado momento se presentan como necesarios para quebrar la estructura de la guerra y el ciclo de la violencia que fragmenta el tejido social, causa daños irreparables y crea ambientes hostiles en contra de la vida, la paz, la justicia y la convivencia civil. No se concibe aquí la separación tajante, clara y absoluta entre 
política y moral, pues se asume una concepción integral de ambos conceptos, es decir, que se entiende que la política se hace desde comprensiones morales y que aquella, al ser la directriz de la organización social, es en sí misma, una apuesta moral. Por ello, no será fácil para el lector diferenciar en algunos apartados estas cuestiones, ni deberá hacer esfuerzos en ello, pues como se aborda en la primera parte del capítulo tercero, en el que se expone la concepción de política que aquí se asume, la política es entendida como un pulso, una visión y una forma de estructurar la sociedad, esto es, como un esfuerzo y una praxis de comunidad para su organización, que implica, no sólo táctica y estrategia, sino sobre todo, la estructura moral del individuo, del sujeto político, del ciudadano.

Ahora bien, para explicitar el problema filosófico de la reconciliación, habrá primero que señalar brevemente el punto de entendimiento del cual se parte sobre el concepto de filosofar. Se comprende el filosofar como un ejercicio reflexivo, analítico y propositivo del ser humano sobre cuestiones de la vida y la sociedad que le suscitan especial atención y que se corresponden con necesidades intelectuales, emocionales y sociales que experimenta el sujeto en determinado momento de su vida. Particularmente, el filosofar político tiene que ver con las preguntas, cuestiones e intereses filosóficos de la vida en comunidad desde el punto de vista organizativo, que implican relaciones de poder en lo que se denomina la comunidad política. Se comprende así mismo, que este ejercicio reflexivo supone no sólo un interés por pensar un asunto, sino que parte de una postura política y una situación social frente a la realidad. Así pues, el filosofar político de la presente investigación se inscribe decididamente en una posición de la comprensión de la filosofía situacional, y concretamente parte del reconocimiento del conflicto social y armado colombiano y, a partir de su realidad, propone una reflexión deontológica para su superación y la construcción de estados de los post acuerdos de paz y la reconciliación social.

Se entiende aquí que la reconciliación es tanto una aspiración como un proceso de reconstrucción de los lazos sociales, de volcarse sobre la política democrática para organizar la sociedad y resolver los conflictos, de asumir la diversidad y el ethos de los pueblos para reconocer y reconocerse en comunidad, de desear cambios estructurales que se dirijan a solucionar problemáticas identificadas como causas del conflicto armado, y también como un proceso consciente y transformador de la identidad y la personalidad de las personas en el que se asumen 
el perdón, la alteridad, la memoria, la reciprocidad y la justicia como pilares de la estructura psicosocial del país del posconflicto. La pregunta concreta que se quiere abordar es ¿cuáles son los aspectos objetivos y subjetivos que resultan fundamentales para la reconciliación en Colombia?

Teniendo en cuenta algunos elementos fundantes del conflicto social y armado colombiano, y algunas secuelas que ha dejado en la memoria nacional, se propuso desarrollar un escrito que dé cuenta de una serie de análisis y propuestas concretas para la superación del mismo en clave de reconciliación. El objetivo es pues, analizar los aspectos subjetivos y objetivos para la reconciliación en Colombia, a partir de una perspectiva de la filosofía política que comprende la política de manera amplia, mencionada con anterioridad. En esta lógica, se plantaron tres objetivos específicos; el primero de ellos, era identificar algunas disciplinas que desarrollaran el problema de la reconciliación, o bien, que fueran relevantes para su estudio, y señalar aspectos principales de su propuesta. Esto con el fin de ubicar el problema conceptual y de enfoque de la reconciliación y revisar categorías y disertaciones claves para la propia propuesta; el segundo objetivo específico fue proponer aspectos que se pueden considerar subjetivos para la reconciliación en Colombia. Estos tienen que ver más con la subjetividad del ser humano, aunque se den en medio de relaciones sociales que requieran incluso de aparatos, estructuras o instituciones; y el tercer objetivo específico planteado fue exponer aspectos objetivos fundamentales para la reconciliación en Colombia, teniendo como suelo del problema una concepción dialógica y organizativa de la política. Estos aspectos se identificaron como elementos claves que detonaron el conflicto social y armado del país en distintas cronologías de su historia, y que por consiguiente, y en la medida en que el mismo conflicto los acentúo como problemas sociales, deben ser asumidos a la hora de pensar la construcción de paz, posconflicto y reconciliación.

Entonces, en la presente investigación, se parte del supuesto de que la reconciliación, como aspiración y como proceso, supone aspectos objetivos (si se quiere materiales e institucionales) y otros subjetivos (o bien propios del individuo en términos internos, de personalidad, de subjetividad) para lograse como resultado o estado parcialmente final, que es, en últimas, un estado de convivencia pacífica, políticamente democrático, económicamente favorable en el 
logro de satisfacción de necesidades de la comunidad, y psicológica y espiritualmente armonioso y sano, que logra quebrar el ciclo de violencias que alientan y se nutren en la guerra. La reconciliación como estado es el reencuentro de seres que han superado un estado de enemistad o enfrentamiento hacia un estado de amistad, de solidaridad, o de hermandad, o bien, de convivencia basada en la alteridad. Se reconoce entonces que en la reconciliación el sujeto se halla en la capacidad de ver el rostro del otro y reconocerse como parte de él, de reconocer en cada sujeto un miembro de la comunidad, de la nación, digno de respeto, y poseedor de derechos y virtudes para el obrar en colectivo.

La hipótesis central del trabajo obedece a la idea de que la reconciliación en Colombia es posible en la medida en que se asuman aspectos subjetivos y objetivos de forma dialéctica. No será posible una reconciliación en la que, por ejemplo, la justicia transicional opere obedeciendo más al principio de la alternatividad penal y pocos esfuerzos se hagan en términos de reparación y reconstrucción del tejido social. O bien, no es posible pensar en la participación política democrática sin asumir una posición, así sea mínima de alteridad. El perdón, la alteridad, la memoria, la justicia y la reciprocidad (aspectos subjetivos destacados de la investigación) se relacionan estrechamente con el concepto de política y las condiciones objetivas identificadas (participación política, distribución de bienes especialmente la tierra, posibilidades del territorio, posconflicto), en el marco de la definición de reconciliación señalado. Esto se comprende por la integridad misma del ser humano, quien tiene tanto necesidades emocionales como materiales, estructuras subjetivas y sociales. Debemos por tanto partir de una mirada holística del sujeto en el entramado social, para comprender por qué aquí, cuando se habla de reconciliación, se proponen asuntos como la memoria, a la vez que hablamos de distribución de la tierra. Al mismo tiempo, la reconciliación política en Colombia no es viable si no asumimos la participación política como una condición sine quo non de la democracia, por ejemplo.

De acuerdo a lo anterior, y asumiendo una postura situacional del filosofar, se propone abordar la reflexión del concepto de reconciliación para pensar un posible estado de posconflicto en Colombia, partiendo de la realidad del conflicto armado actual que asienta sus raíces en una historia de larga duración. Pensar formas de organización social en las que se rescate el lugar de lo humano, desde la dignidad, la libertad, la solidaridad, la justicia, la alteridad y el buen vivir, es 
un imperativo para la filosofía colombiana, para los académicos de distintas disciplinas y para la ciudadanía en general, pues el conocimiento y los saberes deben estar orientados hacia la reflexión sobre las dinámicas sociales y la búsqueda de soluciones a las problemáticas ante las cuales se enfrenta el sujeto y la comunidad.

Teniendo de presente la idea inicial según la cual se entiende la relación dialéctica entre los aspectos objetivos y subjetivos señalados, se propone una estructura de tres capítulos en los que se presentan las reflexiones que constituyen el contenido y sentido de la reconciliación en Colombia. Es posible que, por agrupar estos aspectos en el carácter que se elige para su clasificación (lo subjetivo y lo objetivo), quede la impresión de una falta de articulación del escrito. Sin embargo, se decidió abordar de esta forma la presentación de la investigación, debido a que los elementos se congregan bajo dos apuestas iniciales que los engloban a cada uno en su clasificación. Los aspectos objetivos se comprenden a partir de una concepción deontológica de la política en la cual aquellos se inscriben y se fundamentan, y los aspectos subjetivos se erigen en base a una propuesta arriesgada y utópica de la sociedad del perdón como escenario condicional de la reconciliación, en la que se posibilitan a la vez que se hacen necesarias la alteridad, la memoria, la justicia, la reparación y la reciprocidad. Estos elementos se soportan en la misma concepción de política y proponen parte del contenido moral de la misma.

La investigación se acerca metodológicamente a lo que se podría denominar hermenéutica histórica. Para el caso, la hermenéutica histórica se entiende como el ejercicio cognitivo de interpretación de la realidad a partir de dos supuestos, a saber, el entendido de que la reflexión filosófica parte del contexto concreto de la realidad social y política colombiana y, por lo tanto, es una investigación situada, y en segundo lugar, se hace un esfuerzo por interpretar el devenir histórico reciente del país, que orienta las preguntas y las propuestas reflexivas. En cuanto a lo primero, se aclara que la investigación se ubica en una pregunta político-social que obedece a una situación actual de la realidad colombiana, de donde se comprende que la pregunta filosófica por las posibilidades y formas de la reconciliación surge de una problemática concreta y ubicada históricamente. Con lo anterior se tiene que el interés filosófico se inspira en un escenario social amplio, con particularidades determinadas por las dinámicas propias y singulares del conflicto 
armado y las negociaciones de paz adelantadas entre el gobierno y la insurgencia de las FARCEP.

En este sentido, se parte de la premisa de que tanto el conflicto armado, como las problemáticas por las que se origina y las que de aquel se derivan, son hechos y situaciones históricas, y que, por serlo, esto es, por estar ubicadas en un marco de realidad y concreción de la acción y el discurso de los sujetos y los grupos humanos, tienen el carácter de posibilidad de transformación. Lo anterior nos lleva a destacar que existe una inspiración marcada de la teoría crítica a lo largo de la labor investigativa, en la que se asumen las premisas de esta corriente de pensamiento y se rescatan algunos de sus máximos exponentes, acercándonos a la implementación del método crítico para el filosofar político.

De otro lado, cuando se hace la denominación 'hermenéutica histórica', se apela a la intersección entre el pensar interpretativo y la historia como construcción discursiva con horizonte de pasado/presente para el entendimiento del problema de investigación. Esto se refiere a que el filosofar estuvo en relación constante con la revisión de la historia colombiana, asumiendo una postura crítica frente a la misma, y buscando diversos discursos históricos, de donde incluso se presenta, por las dificultades que se hallan en la historia oficial del país, propuestas como la memoria para la rescritura de la realidad y los sentidos de esta según diversos actores y sujetos sociales. La lectura y relectura de la realidad colombiana arrojó pistas para elaborar, sobretodo, las propuestas que se encuentran en lo denominado como condiciones objetivas para la reconciliación en Colombia, a través de la interpretación de las causas estructurales del conflicto armado que vive el país.

Del mismo modo, la investigación se orientó en algunos apartados por la relación establecida entre la investigadora y algunos escenarios de participación y debate político, tanto académicos como organizativos y sociales, en los cuales se nutre y se sitúan opciones de pensamiento y problematizaciones de la reconciliación en Colombia. Este aspecto resultó fundamental para la construcción categorial de los aspectos subjetivos y objetivos para la reconciliación en Colombia, puesto que las premisas iniciales del trabajo se vieron cruzadas con los discursos y demandas, sobretodo, de algunas víctimas del conflicto armado. A groso modo, la investigación 
analizó reflexivamente diversos discursos, delineándose como un problema trazado entre los límites de la ideología del gobierno, la interpretación de la realidad colombiana por parte de las FARC-EP y las múltiples agendas de las organizaciones sociales, víctimas y procesos comunitarios de defensa de los derechos humanos. En este sentido, se observa una relación directa de la reflexión filosófica con la pregunta por la reconciliación. ¿De qué tipo de reconciliación estamos hablando?

Así pues, y en coherencia con los objetivos señalados, el primer capítulo se presenta como un estudio preliminar para un estado del arte sobre el concepto de reconciliación, buscando reconocer y destacar algunas posiciones disciplinares frente al tema, dando cuenta de los matices y formas de abordar la problemática de la reconciliación desde distintas áreas del saber, teniendo un suelo multidisciplinar desde el cual establecer la reflexión. Así mismo, este capítulo responde al interés de la investigación de ubicar y describir el abordaje conceptual de la temática de la reconciliación. Se trata pues de un recorrido conceptual sucinto de cómo ha sido abordada la reconciliación en distintas disciplinas y saberes, estos son, la teología cristina, la filosofía contemporánea, el derecho, la ciencia política y la sabiduría amerindia.

En la teología cristiana se asume la reconciliación como el restablecimiento de la relación padrehijo entre Dios y el ser humano, que ha sido quebrantada por el pecado del segundo, y se propone así mismo, el perdón y la convivencia entre los hombres entendida como el amor al prójimo. La reconciliación en este sentido es tanto un don de Dios hacia el hombre como la capacidad del hombre para perdonar, que se expresa en primera medida en la vida y obra de Jesucristo. Se trata de que el hijo retorne al padre, y asuma una vida libre de pecados y en armonía con la ley divina, esto es, que vuelva a la comunión con Dios. Se profesa entonces la reconciliación como un sacramento encomendado a la Iglesia, orientado en cuatro fases principales, a saber, el examen de conciencia, el entendimiento y aceptación de los pecados, el arrepentimiento, la confesión y la penitencia.

A pesar de que a lo largo del escrito la posición cristiana no se desarrolla, por el hecho de que la apuesta política se concibe más desde la ciudadanía que desde la hermandad cristiana, el apartado se presenta porque la religión católica representa un referente cultural significativo en la 
sociedad colombiana, siendo parte del sistema mental y religioso de muchos colombianos, y porque la Iglesia Católica ha influido considerablemente en los distintos procesos de paz del país y en la conducción de algunos sucesos del conflicto social y armado, constituyéndose en un actor influyente. No se pretende por lo tanto un desarrollo exhaustivo de la materia, sino que se busca mostrar tanto una forma de entender la reconciliación, como un escenario religioso de dimensión importante en la cultura del país, que en determinado momento cumple un papel central en las posibilidades para la reconciliación.

Posteriormente, la mirada del sacerdote R. Scheiter se presenta por la perspectiva político-moral que expone sobre el proceso de reconciliación. El suelo teológico que se decidió asumir en el desarrollo investigativo fue la propuesta del lugar de la Iglesia en la construcción de paz y reconciliación, desde un sentido social y crítico de la institución. El teólogo expone que la reconciliación es un proceso arduo, porque "no es sólo cuestión de cicatrizar las heridas del recuerdo y aceptar el perdón; se trata también de transformar las estructuras sociales que provocan, promueven y justifican la violencia" (Scheiter, 1998, p.11). Esta perspectiva alienta la mirada bidimensional del problema de la reconciliación: las condiciones subjetivas y las condiciones objetivas.

De otro lado, para abordar el tema de la reconciliación desde la filosofía, se plantea un enfoque desarrollado en Europa a partir de los procesos de posconflicto del siglo XX y que se ha denominado la filosofía de la memoria; esta reconstrucción recoge las propuestas de la Escuela de Frankfurt y los hallazgos más recientes de filósofos como Walter Benjamín, Adorno, Lévinas, Reyes Mate y Dérrida. Los puntos centrales que se destacan de dichas apuestas filosóficas y que son tenidas en cuenta para la investigación son: el lugar de las víctimas en la construcción de procesos de posconflicto, transición y reconciliación, la importancia de la justicia de las víctimas y la construcción de memoria como consecuencia de la crítica a la filosofía de la historia, la desmitificación de las ideas de progreso y civilización, el significado y sentido de la alteridad, y el lugar del sufrimiento y el dolor en la construcción de verdad.

Se podrían encontrar diversas razones para asumir esta relación entre la filosofía de la memoria y la reconciliación. Primero es necesario señalar el escenario común en el que se encuentran las 
propuestas, este es, el conflicto armado, o bien la guerra y el posconflicto. Se dijo ya que la apuesta filosófica de la memoria se inscribe en un contexto de posconflicto en Europa, y que los filósofos que se enuncian tienen una apuesta concreta desde diferentes preguntas sobre el problema de la guerra pero puntualmente sobre el problema del posconflicto. Ahora, el posconflicto puede ser asumido social y políticamente desde distintas posiciones, o bien puede coger rumbos distintos; sin embargo, la apuesta de la presente investigación es la reconciliación como construcción social en un escenario transicional. Y para esta resulta de gran valor los aportes que ofrecen planteamientos de los filósofos abordados en materia de memoria, perdón, alteridad, y justicia, puesto que son conceptos propuestos en el marco de la reflexión por la guerra y sus efectos sobre el sujeto y la sociedad.

Del mismo modo, la propuesta se cimienta en la crítica que se enarbola a la cultura Occidental desarrollada, por ejemplo, por Walter Benjamín, en lo que respecta a su crítica a la filosofía de la historia y la conducción de asuntos sociales. De la filosofía contemporánea se rescatan para el análisis, tres problemas fundamentales, a saber, la clave de la memoria de T. Adorno: recordar para no repetir; el enfoque de la justicia de las víctimas desarrollado por Reyes Mate, reconocido como un aporte filosófico que merece una relectura, puesto que propone rupturas necesarias para pensar la dignificación de las víctimas y la reconciliación como decisión moral con una necesidad política, y que nos permite entender la relación entre justicia y reparación. De J. Derrida se recoge la reflexión a futuro de los retos centrales de su propuesta para el análisis del lugar del perdón y la verdad en la construcción de reconciliación: confesar lo inconfesable y perdonar lo imperdonable. Con E. Lévinas se introduce la reflexión de la alteridad, entendiendo que su propuesta es precisamente una teoría de la alteridad, pero que esta parte, entre otros, del principio del reconocimiento del otro. Estos aspectos se mencionan en el primer capítulo y son desarrollados, junto con otros elementos en el capítulo segundo.

Se identifican así mismo, cuestiones del orden de lo social, lo estructural que se asumen como instituciones, decisiones, prácticas y espacios para la reconciliación. Algunas de estas condiciones se agrupan en lugares cognitivos identificados con el saber de la política y el saber del Derecho. En los estudios de la política se asume la reconciliación desde dos discusiones fundamentales: por un lado, desde el tema de la resolución de conflictos y por otro lado, desde la 
postura democrática de organización social y régimen político. En este sentido, se abordan algunas concepciones de la política y la manera como se ha orientado o se podría abordar la reconciliación en el ámbito público nacional. Se destacan dos concepciones de política, la que teoriza Carl Schmitt, desde una visión dicotómica amigo-enemigo, y la visión de H. Arendt, primada por los conceptos del diálogo, el consenso, el pluralismo y la democracia. Ambas posiciones desarrollan su propio planteamiento sobre la resolución de conflictos. Schmitt hace un análisis de la resolución mediante la guerra, de cómo las clases políticas y las élites armadas construyen la paz por medio de la guerra. Y Arendt propone que la política consiste en el ejercicio libre de la palabra y el voto público, a través del diálogo, el consenso y el ejercicio libre de la opinión pública.

A partir de esta última mirada, se conciben propuestas de la reconciliación como escenario para la participación política, la democracia y el ejercicio de la ciudadanía. Asuntos que serán tenidos en cuenta como principios objetivos para la reconciliación en Colombia y que se desarrollan en el tercer capítulo. A pesar de la mención de las dos propuestas principales de política, es en el capítulo tercero en el que se asume una postura concreta de política que coincide y se retroalimenta con la propuesta que del concepto ofrece el filósofo latinoamericano Enrique Dussel, y que servirá para proponer los aspectos fundantes para un nuevo orden socio-político.

En el Derecho el problema se vuelca principalmente sobre el tema de la justicia transicional, que es una justicia alternativa a la que se acude en procesos transicionales, y que consiste en el tratamiento penal alternativo de crímenes cometidos durante un conflicto armado en pro de la superación del mismo, orientándose desde la defensa de los derechos de las víctimas, el tratamiento de los ex combatientes, y la disposición de medidas administrativas y jurídicas para el logro de la paz, la recuperación de la confianza de los ciudadanos sobre las instituciones estatales y la reconstrucción del Estado de Derecho. La reconciliación en este escenario se propone como uno de los objetivos de la justicia transicional y para ello hace acento, desde su normatividad, en los derechos de las víctimas, a saber, el derecho a la verdad, a la justicia, a la reparación y a la no repetición. 
Por otro lado, desde el enfoque de estudio de la sabiduría indígena la reconciliación comporta reflexiones profundas de la constitución del ser humano, de la comunidad, de la naturaleza y del cosmos en una relación de complementariedad, reciprocidad, corresponsabilidad y armonía; estos principios suponen una ruptura epistemológica y antropológica de comprensión de lo humano, de lo político y de lo social, asuntos que enriquecen la comprensión del problema de la reconciliación desde posturas alternas y sabias. La reconciliación desde la sabiduría indígena implica la reflexión histórica, sanadora y liberadora de los horrores padecidos por millones de indígenas desde la época de la invasión española a partir del siglo XV, así como la situación actual de las comunidades que perviven en el país y que representan un origen físico y simbólico de la nación y de la memoria cultural.

Bajo el propósito de dar cuenta de algunos saberes que aportan a la comprensión de la reconciliación, y teniendo además de presente la responsabilidad histórica en términos de respeto y alteridad con los pueblos indígenas que habitan el país (y en general el continente amerindio), resulta para quien escribe de suma importancia, rescatar algunos preceptos centrales de la sabiduría indígena, que además contextualizan tres propuestas que se abarcar luego en el escrito, estas son, la idea de la decolonialidad en el posconflicto, el principio ético, social y político de la reciprocidad y la concepción de la tierra y el territorio para las culturas étnicas del país.

El primer capítulo abre pues un amplio panorama de categorías, enfoques y sentidos de la reconciliación, para dar paso al abordaje de los aspectos que se consideran fundamentales para dicho propósito socio-político. Reiterando una nota anterior, se aclara que la lógica de desarrollo del escrito no es ascendente o consecutiva en los términos comunes del razonamiento filosófico, en el que un capítulo posterior es resultado de los avances del capítulo precedente. Por la lógica de clasificación que aquí se presenta de los aspectos subjetivos y objetivos para la reconciliación en Colombia, no se ha concebido un orden de menor a mayor nivel de análisis, sino que podríamos decir, que cada capítulo obedece a una lógica propia y a un objetivo específico, siendo que desde la definición de política y reconciliación que se asume, estas lógicas internas se conjugan en un movimiento dialéctico del sujeto y la praxis social. Por lo tanto, será esfuerzo del lector comprender la simbiosis a veces implícita, otras veces explícita, entre los capítulos y contenidos del informe de investigación. De modo que, el panorama completo de la propuesta 
filosófica en torno a la reconciliación en Colombia, se entiende en la conjunción de los capítulos dos y tres, a partir de una visión integracionista de los postulados, y no desde una lógica escalonada de los mismos.

Dejando presente el sentido general de la estructura del escrito, y entrando de lleno en el objetivo principal de la investigación, en el segundo capítulo se proponen cinco conceptos principales que se entienden como los pilares subjetivos fundantes de un nuevo sujeto y un nuevo orden social reconciliado, basado en experiencias de perdón en distintos niveles. Estos son la memoria, la alteridad, la reciprocidad, la justicia y la reparación. De modo general, se propone una sociedad del perdón como la posibilidad de que se dé un auténtico proceso de reconciliación, por el grado de libertad que ofrece a las víctimas, la potencia que da al proceso político en el marco de lo jurídico y por el aporte que ofrece para el quiebre definitivo de las venganzas y rencores que propician y alimentan la violencia en, hasta ahora, interminables ciclos históricos.

Ahora bien, el perdón no es una obligación, y mucho menos una imposición política. A lo largo del escrito se presenta el perdón desde varios sentidos: como un don, entendido desde la teología cristiana; como una herramienta del orden legislativo y judicial de competencia del Estado para con los excombatientes; y en sentido amplio, personal y colectivo, como un acto de liberación, razón por la cual, el perdón no se obliga, pero sí se permite. No hay que confundir entonces el escenario y la iniciativa del perdón, con imposiciones morales y menos políticas. Se está proponiendo asumir niveles de perdón y generar condiciones comunitarias y políticas para el mismo. Sin embargo, se plantea que existe un perdón sin el cual la reconciliación sería inviable. Se trata de una especie de perdón social que se asume como una experiencia de convivencia, de aceptación del otro en términos de ciudadanía, luego de experiencias profundas de dolor y victimización. La clave a través de la cual se plantea el perdón, es como una ruptura social frente a la manera violenta y vengativa de resolver los conflictos. El perdón no implica el olvido, ni la justicia se supedita al perdón. El perdón tampoco implica el amor o la demostración de afecto de la víctima para con el victimario. El perdón es un estado de libertad de la víctima frente a la memoria dolorosa y el sentimiento de rencor, resentimiento y/o frustración respecto del verdugo y del acto victimizante. Se delinearan entonces momentos y niveles del perdón, diferenciando 
estadios personales, sociales y políticos del mismo, todos necesarios para la concepción y el futuro de la reconciliación.

En el escrito se asume que en un proceso de reconciliación es fundamental partir de la recomprensión de la historia del país, construida desde la memoria, una memoria que resulta histórica, colectiva, cultural y que se constituye como verdad. Se trató entonces de exponer una serie de cuestiones y cuestionamientos frente al significado y sentido de la memoria, permitiendo hacer un recuento sucinto de las conceptualizaciones más comunes sobre el tema.

Quedó abierta una cuestión en especial, que apenas se menciona, y corresponde con el concepto de la "no memoria". La no memoria como el derecho a guardar para sí los recuerdos, vivencias y experiencias, o en un sentido más existencial, a permitirse olvidar, porque el recuerdo es doloroso y causa sufrimiento. La "no memoria" como la decisión de seguir adelante, de cerrar el ciclo de dolor causado por la violencia. En este apartado sobre la memoria, se recogen varias miradas que suponen distintos actores del orden social, entre ellos, la mirada de la víctima, y la mirada del victimario, o el cómplice. Para exponer la mirada de la víctima se acude a los planteamientos de Adorno, interpretando una clave central que permite la conexidad que aquí se propone entre memoria y reconciliación, este es, el postulado "recordar para no repetir". Y en cuando a otros actores de la memoria, se rescata la reflexión que sobre la parrhesía desarrolla Foucault, señalando particularmente la verdad que guardan los funcionarios públicos y otros agentes que en determinado momento y en casos concretos, tienen que ver con las causas del conflicto armado, o con hechos puntuales de guerra y violación de derechos humanos, y que se considera, son relatos que se deben tener en cuenta en ese propósito de reconstrucción de la historia del país.

De otro lado, se asume como fundamento del nuevo orden social reconciliado, el principio de la alteridad, como el reconocimiento de la otredad, del otro desde un sentido de responsabilidad. Esto se hace por una razón fundamental y es que la violencia política, entre otros sentidos, es la negación del otro. Al otro, como diferente, se le entiende como obstáculo, como objetivo militar, más no como opositor político, civil. Es menester abordar los fundamentos filosóficos, desde una comprensión ética de la alteridad, para cimentar formas de relacionamiento social que permitan 
la vida, el intercambio y la sociabilidad. Estos fundamentos se encuentran en la propuesta ética de Lévinas y su teoría de la alteridad, que se basa, en últimas en los principios de interpelación del otro y de reconocimiento y responsabilidad con el otro. La alteridad implica la comprensión de que el ser del yo hace parte del ser del otro, y que por lo tanto, se es constitutivo uno del otro, por lo que se establece una alarma que provoca el respeto, la consideración y la responsabilidad para con el otro (Lévinas).

En el mismo orden y un tanto de la mano de la categoría de la alteridad, se expone la reciprocidad como la forma en la que deben entenderse las relaciones sociales, significando reparto de culpas y responsabilidades, pero sobre todo, como forma de relación que se sustente en la solidaridad y el trabajo mutuo para el logro de la convivencia pacífica. Se plantea que la reciprocidad es un principio constitutivo de las comunidades y resulta esencial en los grupos humanos que de manera colectiva y por vía política, deciden pasar de un estado de conflicto armado a un estado de paz.

En este sentido, podemos hablar de por lo menos dos dimensiones de la reciprocidad. Por un lado, la reciprocidad se refiere a la relación que se debe establecer entre las partes negociantes para establecer acuerdos. En el caso concreto colombiano y refiriéndonos al proceso citado, tanto el Gobierno Nacional y sus Fuerzas Militares, como la dirigencia política y las filas de las FARC-EP, deben reconocer sus errores, la comisión de crímenes y su culpa en los hechos del conflicto social y armado. De otro lado, la reciprocidad se esboza como un principio esencial de las comunidades, comprendido no por la voluntad de ser parte de otro o tener parte en el otro, sino por la composición misma del todo. En este sentido nos aportan la sabiduría indígena y propiamente la cultura quechua, ampliamente estudiada por Estermann.

La justicia es un asunto polémico pero indispensable a la hora de plantear el tema de la reconciliación. Al respecto se describen algunas definiciones del concepto y se profundiza en la propuesta de Reyes Mate sobre la justicia de las víctimas y por otro lado, en la justicia social como enfoque necesario, para llegar a algunas reflexiones en torno a la reparación. Del concepto de justicia que propone Reyes Mate, se rescata principalmente su carácter anamnético y las claves que ofrece para la reparación. Dentro de la justicia social se aborda el tema de la justicia 
distributiva como base filosófica de algunos postulados del tercer capítulo, en lo que respecta sobre todo a la distribución de la tierra en Colombia, aportes que se enfocan al requisito básico de la supresión de las desigualdades sociales, de la pobreza infundada por el orden políticoeconómico, y a la necesaria apertura política. A pesar de los esfuerzos filosóficos y políticos, la reparación se somete al duro juicio de algunas realidades: reparar lo irreparable, por lo que se habla de unos mínimos de justicia en clave de reparación para dimensionar posibilidades para la reconciliación.

En el tercer y último capítulo se abordan algunas cuestiones sociales, políticas e institucionales que se configuran como una propuesta de los cambios estructurales en las distintas dimensiones de la sociedad que deben ser asumidos en los procesos de paz y sobre todo, en la pragmática de la política de la reconciliación. Para ello se plantea inicialmente el problema de la política en sí, esto es, la pregunta concreta de qué se entiende por política y por el ejercicio de lo político. Aquí se entiende la política como la función pública del ordenamiento de la comunidad, basada en principios de confianza, solidaridad, trabajo mutuo, diálogo, reciprocidad y alteridad, que se ve alimentada por la reconstrucción de la verdad como memoria histórica de un colectivo y que se orienta al logro del buen vivir y la satisfacción de las necesidades de la comunidad. El ordenamiento de la comunidad supone la construcción de acuerdos comunes, y en el caso puntual de un escenario de posconflicto, requiere la comprensión de los hechos causantes de violencias. Del mismo modo, dicha comprensión depende de la capacidad de diálogo y la posibilidad de encuentro de las partes y actores involucrados y/o afectados por distintas acciones y contextos de la guerra.

Posteriormente, se aborda la cuestión del posconflicto. Como escenario que abre paso a la constitución de un nuevo orden social, se sustenta principalmente en la apertura política de la organización y constitución de lo público, en el reconocimiento de la dignidad humana y la participación política de sectores históricamente excluidos y negados de la sociedad, y se presenta, por lo tanto, como un espacio-tiempo en el que la comunidad se re-piensa en su sentido de coexistencia de sujetos que emprende la labor comunal de reconstrucción social, de autodefinición política (en el sentido normativo y pragmático-organizativo), y de puesta en común de los principios éticos del orden socio-cultural. 
Es claro que el conflicto social y armado colombiano se debe a múltiples y diversas causas, que serían inabarcables en profundidad en un trabajo de este alcance. Por lo tanto, se ha hecho un esfuerzo por definir algunos de los problemas sociales más relevantes que producen y reproducen el conflicto armado, teniendo de presente que la reconciliación se propone como ese proceso que busca quebrar ciclos de violencia, resolviendo las causas de la disputa bélica y el ejercicio armado para la resolución de conflictos sociales. A grandes rasgos, estos problemas son: la inequitativa distribución de la tierra, la dirección estrecha y excluyente del poder político colombiano, la colonialidad del poder y del saber, y más recientemente, la aplicación desequilibrada de los principios de la justicia transicional.

En el estudio situado de la realidad colombiana, no es posible ignorar la crudeza y radicalidad con que ha sucedido el conflicto social y armado en el campo, o bien, en el sector rural del país. La guerra se ha debatido en gran medida por la conquista y dominio del territorio natural de los pueblos indígenas y afros, de las tierras de campesinos y campesinas, en un afán desmesurado por desarrollar una economía extractivista alentada en gran medida por poderes económicos internacionales. Basta con recordar la penosa época de las caucherías en el Amazonas (finales del siglo XIX y principios del XX), los desmanes de la Fuerza Pública y las atrocidades cometidas en los enclaves económicos de las plantaciones de bananos en el Urabá, en la extracción petrolera en Barrancabermeja, las actuales problemáticas y violencias generadas a causa y en medio del desarrollo de megaproyectos, tales como hidroeléctricas, vías de comunicación, entre otras, y la permisión de la extracción de recursos naturales a gran escala, como el caso de la gran minería del oro, por ejemplo. En este sentido, múltiples conflictos sociales se han generado por la confluencia de estas variables: violencia, control poblacional, control territorial, desarrollo económico, poder político, pobreza y apropiación de tierras, situaciones que se presentan en medio del fenómeno inacabado de la colonialidad.

Entonces, pensar un escenario posible de reconciliación, que se asume en parte como la superación del conflicto armado, debe considerar la problemática rural, agraria del país, debe considerar del mismo modo, las condiciones necesarias para que las víctimas de las causas del conflicto armado tengan una opción distinta de vida en clave de buen vivir, de bienestar y 
justicia social, con el fin de interrumpir las fuerzas que alientan a la guerra y de transformar las condiciones de vida que generan pobreza, marginalidad y exclusión. Se considera pretensioso y un tanto irreal, suponer que la paz y la reconciliación en Colombia son posibles si no se asume social, económica y políticamente la distribución de la tierra, el reconocimiento de los derechos de los campesinos, de los pueblos indígenas y de las comunidades afros, poblaciones que han sido fuerte e históricamente aporreadas por la dinámica y los hechos de la guerra.

Partiendo de lo anterior, se hacen propuestas como la redistribución de la tierra, el reconocimiento de los derechos de los campesinos y campesinas, el ejercicio de la soberanía alimentaria, la protección y ampliación de territorios de comunidades indígenas y afros, la creación y consolidación de zonas de reserva campesinas, que hacen parte del entramado institucional que se propone como alternativa a las causas del conflicto armado. Del mismo modo, resulta esencial en el dimensionamiento de la política que se avizora, la apertura del espectro político y la garantía de la participación política, asumiendo una propuesta de poder local que se relaciona constructivamente con niveles de poder regional y nacional. Esto implica que se reconozca y se ejerzan autonomías locales, sin perder el horizonte de la soberanía nacional. Finalmente se hace hincapié en la necesidad de una educación para la paz en el país, que asiente sus raíces en una educación pensada para la liberación, la emancipación y la convivencia, haciendo uso del arte como proceso creativo transformador de realidades.

La transformación de las estructuras sociales, económicas y políticas que propician y alientan el conflicto social y armado colombiano es una condición material indispensable para el logro de una paz duradera, en el entendido de la paz positiva que la investigación asume. En el escrito apenas se señalan algunas puntadas de los cambios económicos que resultan necesarios y constitutivos de la propuesta, y queda para futuras investigaciones, profundizar en el planteamiento de un sistema económico coherente con el desarrollo humano para el buen vivir y la garantía y libre ejercicio de los derechos humanos. El nuevo orden social del posconflicto para la reconciliación debe ser producto de acuerdos mínimos e ideales máximos en justa proporción con las condiciones institucionales y las funciones públicas de la comunidad política. Y por eso, se plantea que uno de los componentes básicos del proceso transformador es el mejoramiento de 
las condiciones de vida de los sujetos, habitantes del orden social. En este aspecto, se conjugan los cambios sociales con el ideal y la idealidad subjetiva de la justicia social.

Se puede señalar que la investigación se situó en un horizonte político de la filosofía comprendiendo entonces que la filosofía es una acción política, entre tantas-, buscando comprender y proponer criterios y acciones claves de reconstrucción social, de posconflicto, de manejo administrativo de lo público, de perspectiva a un escenario posible de acuerdos de paz entre el Gobierno Nacional y las FACR-EP. Pero el tema no se agota allí, así como no se agota el conflicto del país. Existe en el trabajo una labor de etnografía filosófica que consistió en la exposición y análisis de la problemática del conflicto y la construcción de la paz de población colombiana afectada directamente por el conflicto armado. De aquí resulta clave la dimensión del territorio como horizonte y posibilidad de vida de las comunidades y los grupos étnicos colombianos, del lugar de la tierra en la reparación de las víctimas y la solución real del problema de la tierra en Colombia. Lo anterior comprende: derechos campesinos, reconocimiento de los Derechos de los Pueblos Indígenas y de las comunidades negras, redistribución de la tierra y re distribución agraria de la tierra, políticas básicas como la soberanía alimentaria, y enfoques de educación y cultura como iniciativas de paz social.

Se hace conciencia de que para la reconciliación en Colombia, son muchos más los elementos subjetivos y objetivos que aportan al proceso y que no han sido abordados. Por ejemplo, se destaca el lugar del problema psicosocial tanto de los sujetos como de la sociedad en su conjunto respecto de las heridas y enfermedades causadas por los hechos y el ambiente de la guerra. Sin embargo, por ser un tema un tanto ajeno al conocimiento de quien escribe, se decidió no abordar este componente, que de todos modos, se insiste, resulta fundamental en la reconstrucción del tejido social y la apertura psicológica para la paz y la reconciliación. Sobre el tema, y concretamente relacionado con la dignidad, el perdón y con la necesidad de la sanación profunda del ser en comunidad, se recomienda una lectura de la propuesta de un enfoque investigativo y vivencial inspirado, nutrido y orientado desde la sabiduría indígena, denominado psicología ancestral, que ha sido abordado por el psicólogo Luis E. Romero. 
De otro lado, es preciso señalar que resulta necesario para futuras investigaciones, profundizar en el tema de educación para la paz, teniendo de presente las líneas de análisis de se logran establecer en el trabajo, las cuales son, la cultura y el arte como medios y expresiones fundantes de la educación, y la liberación como proceso y fin último de la misma. La liberación en tanto emancipación se entiende en doble vía; una emancipación de las estructuras mentales de opresión y, la emancipación frente a las estructuras sociales de dominación. Del mismo modo, se identifican otros asuntos para próximas investigaciones que pueden ser abordados también desde la teoría política, incluso desde la economía política, y que se refieren propiamente a los cambios económicos necesarios para el posconflicto, esto es, a las transiciones económicas que se deben operar para la reconciliación en Colombia. También el tema general de los problemas ambientales y su relación con el conflicto armado, en clave de reconciliación, es un asunto que amerita ser abordado y re prensado desde un enfoque crítico de la filosofía latinoamericana, considerando en ésta importantes aportes al respecto, por su condición epistémica radical.

De manera sucinta, se puede enunciar que el aporte filosófico de la investigación se da en dos vías. Por un lado, en la ratificación de la propuesta de la filosofía situada, esto es, la idea de la importancia de que la filosofía surja de un contexto y una problemática que aqueja en determinado contexto a una sociedad o colectividad, o individuo. En este sentido, la investigación es enfática en la localidad del problema de investigación, que parte de un espacio concreto, y pretende escalar en la reflexión, proyectándose a la universalidad de los postulados. La universalidad en este caso no se descarta, pero tampoco es la motivación máxima del estudio, ya que lo que este pretende es aportar en la reflexión desde el caso concreto colombiano para sí mismo. De otro lado, se rescata el aporte a la filosofía política colombiana, en el entendido de la actualización de reflexiones y propuestas de vieja data, que hoy día, en medio del proceso de diálogos de paz, recobran una importancia central para pensar la política y lo político. Se destaca entonces la definición de política que se plantea en el texto y la relación intrínseca que se establece entre esta y la moral. La investigación es un esfuerzo por señalar la complejidad y polisemia del concepto de la reconciliación, y logra abordar tanto reflexiones categoriales con un grado importante de abstracción, como propuestas programáticas y políticas concretas, intentando una relación dialéctica entre ambos escenarios para la reconciliación en Colombia. 


\section{CAPÍTULO I \\ UBICACIÓN CONCEPTUAL DEL CONCEPTO DE RECONCILIACIÓN. DISCIPLINAS, ENFOQUES Y SABERES}

La reconciliación es un concepto polisémico que presenta serias dificultades a la hora de ser abordado en la medida en que, dentro de los significados que lo constituyen, se usan muchas veces sin contextualizar categorías que en sí mismas son complejas, como perdón, conciliación, justicia, memoria, conflicto, ofensa, autoridad, posconflicto, entre otras, y que carecen de la precisión y profundidad que comportan los actos y escenarios que representan. Del mismo modo, la reconciliación ha sido significada desde distintas disciplinas o campos del conocimiento que incluso llegan a oponerse en sus principios y postulados últimos, lo que pone en evidencia paradójicamente, el carácter conflictivo del concepto mismo. Es importante hacer un esfuerzo filosófico por desentrañar el sentido de la reconciliación y desenmarañar un poco los significados y usos que se dan de los conceptos empleados para definirla, poniendo límites y reevaluando el alcance de los mismos para contextos complejos como el actual colombiano.

La doctrina que tradicionalmente ha desarrollado el marco teórico de la reconciliación ha sido la teología teniendo como fuente principal el Evangelio, el Nuevo Testamento de las Sagradas Escrituras. Sin embargo, en la actualidad, sobretodo en la historia reciente del siglo XX mundial, la ciencia política, el Derecho y la filosofía crítica, han hecho suya la tarea de definir, significar y proponer las formas y sentidos de la reconciliación, ahora desde una mirada de los procesos sociales y políticos que se han dado en los distintos continentes en lo referente a las situaciones de posguerra, transiciones democráticas y tratamiento y superación de conflictos armados internos. En este sentido, la teoría de la resolución de conflictos, el desarrollo y actualización del Derecho Internacional Humanitario, la justicia transicional y la filosofía de la memoria, son ejemplos de las formas de progreso intelectual acaecidos desde el pasado siglo hasta nuestros días.

Teniendo en cuenta lo anterior, este primer capítulo pretende ofrecer una descripción sobre los fundamentos filosóficos de la reconciliación desde las dimensiones más representativas que han 
abordado el concepto. Es importante reconocer en cada una de ellas las características del concepto, sus principios y algunos acontecimientos que han sido parte constitutiva del mismo, con el fin de tener claros los componentes y límites que cada una de las disciplinas ofrece a la comprensión y construcción del concepto de la reconciliación en sentido universal y también para el caso colombiano, esquematizando algunas particularidades del contexto nacional y actual del conflicto armado.

La importancia de tal descripción radica en dos cuestiones fundamentales: por un lado, en la diversidad significativa que ha recibido el vocablo reconciliación, y en la misma línea, por la dificultad que puede suscitar esa variedad a la hora de llegar a acuerdos que permitan darle forma y sustancia a las políticas, iniciativas, concepciones y programas para la reconciliación, sobre todo en lo referente a quiénes deben impulsar procesos de reconciliación, si el hombre tiene o no la capacidad de afrontar el pasado y reconstruir un futuro no violento, cómo sería un sociedad reconciliada, hasta dónde se puede reconciliar el hombre y con quién; asuntos que se traducen en problemas de legitimidad, autoridad, justicia, perdón, condición humana y comunidad política, entre otros.

Las disciplinas a que se hace referencia establecen un tratamiento específico dado frente a la reconciliación y responden a parámetros teológicos, filosóficos, políticos y jurídicos. Se ha querido de igual manera introducir conceptos y sentidos de una mirada no occidental, en este caso de lo que se ha venido denominando la sabiduría indígena de culturas amerindianas, para acercarnos al pensamiento y sentir ancestral, reconociendo el gran aporte que ofrecen a la construcción del concepto de reconciliación. Serán pues objeto de estudio lo referente a la teología de la religión católica, la filosofía de la memoria, la ciencia política, el Derecho y el pensamiento ancestral indígena. Es preciso aclarar que el objetivo en este apartado es dar cuenta, a modo general, de los principales elementos sobre los cuales estas disciplinas, desde la representación de algunos autores claves, corrientes y/o escuelas de pensamiento, han dado significado a la reconciliación. Aunque algunos enfoques no presentan una definición concreta de la reconciliación, si es posible avanzar en la interpretación de algunas posturas desde el enfoque de la reconciliación, haciendo notar las posibilidades y límites en cuanto a la definición del concepto. 


\subsection{Elementos fundamentales de la reconciliación en la teología de la Religión Católica: relaciones entre Dios y el hombre y entre la Iglesia y la sociedad}

En términos generales desde la concepción cristiana, la reconciliación hace referencia al estado al cual deben los hombres volver con Dios cuando su vida ha caído en el pecado. La venida de Jesucristo a la tierra, es decir, la entrega que Dios hizo de su hijo a sus hermanos en la tierra para asegurar el perdón de sus pecados y su consiguiente salvación, significó la reconciliación entre Dios y los hombres, siendo Dios el agente del perdón verdadero. Así, el Nuevo Testamento de las Sagradas Escrituras, da cuenta del camino que consolidó la reconciliación a través de la experiencia de Jesús entre los hombres. Por lo tanto, la reconciliación sería un estado preconcebido o prefabricado por la vida y obra de Jesús para los cristianos, que precede incluso el pecado mismo. Así, a pesar de que el proceso supone un avance en el reconocimiento del pecado, el arrepentimiento, etc., se trata más bien de volver, de ir hacia atrás al estado de encuentro y aceptación de Dios y sus mandatos.

El hombre debe reconciliarse con el reino de Dios a través de su misma libertad para hacerlo. Y esta posibilidad está dada, como se dijo anteriormente por la venida de Jesús a la tierra, por el sacrificio que significó la venida y muerte del hijo de Dios. Entonces la reconciliación es el sacramento $^{1}$ que pretende volver a un estado de amistad con Dios y entre humanos, de una relación que se ha desvirtuado por los pecados cometidos después del sacramento del bautismo. En este sentido, la reconciliación se refiere a un estado espiritual y a la aplicación de los principios de la moral que deriva de la ley divina contenidos breve y contundentemente en los mandamientos anunciados por Moisés. Del mismo modo, la reconciliación entre los hombres comporta el sentido de la hermandad que se expresa en la máxima "amar al prójimo como a ti mismo", dando cuenta que la relación entre hombres es de carácter fraternal, de un prójimo con otro, unidos en la relación de hijos de Dios.

\footnotetext{
${ }^{1}$ Un sacramento es el acto ritual a través del cual el hombre exterioriza el ser hijo de Dios aceptando la espiritualidad, mandamientos y normas de las Sagradas Escrituras. Los sacramentos fueron instituidos por Jesús cuando descendió a la tierra.
} 
La reconciliación en la Religión Católica parte del hecho primario de la creación del universo en la que Dios crea al hombre a su imagen y semejanza, libre de pecado y le dota de los bienes necesarios para la reproducción de vida en una armonía casi perfecta. Es casi perfecta por el hecho de que el pecado aunque ausente en la vida del hombre, tiene aún posibilidades que se abren por la existencia de la tentación y el carácter libre del hombre que se manifiesta en su capacidad de decisión. La comisión primaria del pecado de los primeros hombres del paraíso, marca la ruptura de la relación del hombre con Dios y desata la furia de este sobre aquel, hecho que será transformado con la idea del perdón, la reconciliación y la vida de amor que trae la llegada de Jesucristo. Claramente se puede notar que la reconciliación trata entonces de volver al origen, de retornar a un estado de relación armoniosa y libre de pecado entre Dios y el hombre. La reconciliación supone entonces, no sólo un camino de cambio, sino sobre todo un camino de retorno, de ir a atrás, cuando no existía el pecado, esto es, de conducir una vida bajo la ley divina y el reencuentro con Dios. Sin embargo, la reconciliación, como se anotó anteriormente, se sustenta así mismo en la reconciliación del hombre con su propia especie.

La reconciliación de Dios con la humanidad incluye evidentemente la reconciliación de la humanidad consigo misma y, por consiguiente, la superación de todas las formas de opresión y dominación causantes de los conflictos, incluidas las guerras. Pero eso no significa que esta reconciliación se hará espontáneamente o por un milagro, intervención forzada de Dios, por ejemplo, con el envío de miles de ángeles. El reino de Dios y la reconciliación se realizan a través de los actos humanos. Éstos reciben la inspiración y la fuerza del Espíritu pero nunca actúan sin la libertad humana. Tienden a liberar esta libertad y por tanto a aumentar la responsabilidad de los agentes humanos. (Comblin, 2001, parr.1)

Lo que Comblin expresa es que, aunque las fuerzas espirituales estén dadas para la reconciliación, ésta depende en gran medida de los actos humanos, de la praxis del hombre concreto en lugares y tiempos concretos. La reconciliación no se logra, desde este punto de vista, exclusivamente por obra y gracia de fuerzas espirituales, tipo milagros, sino que supone ante todo la voluntad y acto humanos para su consecución. Y así mismo, se abre la reflexión sobre la necesidad de superar todas las formas de opresión y dominación, esto es, todas las relaciones que ponen a un individuo o grupo humano por encima de otro en una relación asimétrica de dominio. 
Se presentan acá dos principios básicos para la reconciliación: la libertad y la responsabilidad humanas.

Ahora bien, la reconciliación se puede entender hoy en dos vías teológicas, basándonos en la visión cristiana; por un lado, como el proceso personal y espiritual que el hombre realiza para volver a Dios, es decir, para estar en comunión con Dios, y por otro lado, desde el papel que cumple la Iglesia como portavoz del mensaje de Dios y su acción hacia la reconciliación de los hombres con él y entre ellos mismos como hermanos. Así, algunos teólogos se especializan en el proceso como tal de la reconciliación y otros la exponen como misión de la Iglesia. En cuanto al proceso personal en que se constituye, esto es, como sacramento, la reconciliación debe hacerse a través de actos sinceros y profundos de voluntad y conciencia del pecado, incluyendo las siguientes fases: examen de conciencia, entendimiento y aceptación de los pecados, arrepentimiento, confesión y penitencia.

A grandes rasgos, la penitencia incluye actos de contrición, confesión y satisfacción. El acto de contrición es la voluntad expresa de un dolor profundo del alma del penitente, que reconoce y siente como abominable el pecado cometido; es el dolor del pecado que promueve el arrepentimiento. Existen dos formas de contrición, la perfecta y la imperfecta. La primera sucede cuando el amor de Dios mismo brota en el hombre y se perdona el pecado. La segunda es un don de Dios dado al hombre a través del Espíritu Santo y puede surgir del temor al castigo o de la abominación del pecado. La contrición significa recogimiento, un paso en el encuentro consigo mismo en reflexión sobre los actos pecaminosos y sus posibles efectos (Vaticano).

La confesión de los pecados es un acto seguido del anterior y consiste en dar testimonio de que se ha caído en pecado, confesar de corazón al sacerdote el pecado cometido. La confesión consiste en hablar con el corazón de la verdad experimentada. Se trata también de un acto de liberación y de responsabilidad. Finalmente, la satisfacción es el acto sustentado en la penitencia como tal. Consiste en reconocer el dolor y perjuicio causado a Dios, a sí mismo y al prójimo por efecto de los pecados, y desear de corazón resarcir dicho daño. Es un acto de reparación que depende en alguna medida de los sentimientos y actos del hombre, pero que en sentido estricto es posible sólo en el mismo Jesucristo (Vaticano). 
El sacramento de la reconciliación (perdón o confesión) es el que propende por la reconciliación con Dios y con la iglesia (el prójimo) en un acto de perdón y conversión. La conversión implica para el hombre salir de los pecados, convertirse en nombre del Señor a una vida libre de pecados, situación que debe ser el resultado de un examen de conciencia (que se practica principalmente en una evaluación de las experiencias respecto a los 10 mandamientos) y de un verdadero arrepentimiento, del entendimiento del pecado y la renuncia a este. Según Murray (2007),

$\mathrm{El}$ arrepentimiento queda admirablemente definido en el Catecismo Menor: «El arrepentimiento para vida es una gracia salvadora por la cual el pecador, por un verdadero sentimiento de su pecado y la comprensión de la misericordia de Dios en Cristo, con dolor y odio contra su pecado se aparta de él volviéndose a Dios, con un pleno propósito y empresa de una nueva obediencia». (p.111)

El arrepentimiento debe conducir a la intención de enmienda, que consiste en la firme convicción y propósito de no volver a pecar. Así mismo, del arrepentimiento viene la confesión, esto es, dar cuenta al sacerdote del pecado, con lo que este da la absolución de parte de él, y Dios da perdón y paz. Siendo el sacerdote el representante espiritual en la tierra, es él quien a través de la gracia divina perdona los pecados. Hay que tener en cuenta que el acto de confesión supone la virtud de la verdad, por lo tanto, la confesión debe ser la sinceridad expuesta y declarada de un hecho, del pecado. La confesión sincera será un paso fundamental al que se puede llegar por el sentimiento de culpa, por el reconocimiento del pecado y por el arrepentimiento. Constituye el espacio en el cual se experimenta un grado de liberación del sentimiento de culpa. Al respecto dice la Biblia que,

La oración de fe restaurará al enfermo, y el Señor lo levantará, y si ha cometido pecados le serán perdonados. Por tanto confesaos vuestros pecados unos a otros, y orad unos por otros para que seáis sanados. La oración eficaz del justo puede lograr mucho. (Santiago 5: 15,16)

El que encubre sus pecados no prosperará, más el que los confiesa y se aparta alcanzará misericordia. (Proverbios 28:13) 
De este modo, la reconciliación es el resultado de un cambio de actitud y consiguientemente un cambio en la relación con Dios y con el prójimo, hacia un sentido de amor y de paz, oponiéndose a formas de enemistad y de guerra. Es Jesucristo en su calidad de redentor el que abrió las puertas de la reconciliación entre los hombres y Dios y entre aquellos. Dice la Biblia al respecto: "porque si siendo enemigos, fuimos reconciliados con Dios por la muerte de su hijo, mucho más, estando reconciliados, seremos salvos por su vida" (Romanos 5:10). Volviendo sobre la penitencia o satisfacción, se consagra que esta se refiere a la aceptación de lo que el sacerdote mande para la reparación de los pecados. Se trata como se mencionó anteriormente, del momento en que se reparan los daños causados. Por lo tanto, el perdón de los pecados no clausura el proceso de reconciliación, sino que el pecador debe dirigir sus esfuerzos hacia la reparación, procurando remediar los daños causados con sus actos, puesto que cada pecado tiene consecuencias que deben ser reparadas.

El sacerdote Robert J. Schreiter aborda el tema de la reconciliación en dos textos principalmente: Violencia y reconciliación. Misión y ministerio en un orden social en cambio y El ministerio de la reconciliación. Espiritualidad y estrategias. En el primero, que será la fuente de referencia en este apartado, establece un panorama del orden social cambiante, es decir, de la reconfiguración del orden mundial tras la caída de la Unión Soviética y las nuevas correlaciones del poder, con el fin de situar las características del mundo que necesita reconciliarse, esto es, de los contextos sociales que demandan procesos de reconciliación, hablando un poco de lo ésta es y no es. En un segundo momento expone algunas consideraciones en torno a la violencia y al sufrimiento y las posibilidades de superarlo. En el tercer apartado habla de la reconciliación en los textos bíblicos, poniendo en el centro del estudio los escritos de Pablo y los deuteropaulinos, dando cuenta de la visión cristiana de la reconciliación. En el cuarto y último capítulo, Schreiter trabaja la cuestión de si la iglesia cristiana puede acompañar o promover procesos de reconciliación.

Schreiter (1998) aclara de antemano que su reflexión sobre la reconciliación se inscribe en el contexto político, es decir, que su escenario de análisis es el orden social, y que sus aportes serán desde la visión cristiana de la reconciliación. Reitera que su "principal preocupación es de orden social y se halla referida principalmente a los acontecimientos que suceden a un período de violencia" (p.35). De ahí la importancia de rescatar sus reflexiones en la medida en que se sitúan 
en el mismo contexto de la presente investigación. En este orden de ideas, Schreiter (1998) afirma que,

La reconciliación es una meta intensamente deseada, aunque esquiva. Parte del problema es la enorme magnitud de la tarea, tan grande que parece prácticamente inalcanzable. No es sólo cuestión de cicatrizar las heridas del recuerdo y aceptar el perdón; se trata también de transformar las estructuras sociales que provocan, promueven y justifican la violencia. La reconciliación resulta escurridiza, debido también a que las personas a veces exigimos lo que no se debe a quien no se debe en el momento menos oportuno. (...) El deseo impaciente de dejar atrás las cargas del pasado, muchas veces insoportables, puede llegar a obstaculizar cualquier posible reconciliación, en lugar de favorecerla. (p.11-12)

El autor señala por lo menos dos dimensiones de la reconciliación: una que se refiere a un plano interior y con una carga emocional y psicológica fuerte (cicatrizar heridas y aceptar el perdón) y otra que alude a una dimensión social y más política (transformación de estructuras sociales). Ambas aparecen como parte de lo mismo en términos globales del entendimiento de la reconciliación como meta deseada. Y en este sentido expone que el centro de su reflexión es la "liberación de la violencia y del sufrimiento por ella causado, como condición de posibilidad del proceso de reconciliación" (Schreiter, 1998, p.49).

De modo general, se puede exponer que Schreiter comprende dos bases significantes socialmente de la reconciliación, a saber, la posibilidad de asumir y redimir el sufrimiento de las víctimas, por un lado, y la necesidad de saber y comprender las causas de la violencia, por otro lado. Ambos con el fin de establecer un nuevo orden social más justo y pacífico, que logre evitar que la "rueda de la violencia" siga girando. Estas dos acciones suponen asumir el proceso de la reconciliación en su propio ritmo, sin apresurarse al logro de una meta establecida en sí misma, es decir, a pesar de que la reconciliación sea definida como meta, el autor la comprende así mismo como un proceso difícil y prolongado, en el que se debe medir con cautela la dimensión de las acciones y el espacio-tiempo para las mismas, sin forzar ni evadir asuntos esenciales, como por ejemplo, la rememoración de los hechos violentos y la condición del sufrimiento de las víctimas. De modo que, "la reconciliación no puede ser un proceso apresurado, que exige respetar -y a menudo restaurar- la dignidad humana de las víctimas” (Schreiter, 1998, p.38). Esta 
afirmación será retomada más adelante en el siguiente capítulo en cuanto se aborde el tema de la memoria y su relación con la reconciliación.

El autor propone por lo menos tres definiciones erróneas de la reconciliación, o más bien, explica tres formas falsas de comprenderla, aduciendo lo que no es la reconciliación. La primera de ellas la denomina como la "la paz apresurada" y consiste básicamente en poner como fin único la paz, obviando procesos de transformación, y sobre todo procesos de redención del sufrimiento de las víctimas. Esta forma errónea de reconciliación "intenta solventar una historia de violencia suprimiendo su recuerdo. Para dejar atrás la violencia vivida y hacer posible así un nuevo comienzo, este enfoque recomienda actuar como si la violencia no hubiese tenido lugar" (Schreiter, 1998, p.36). La segunda forma de reconciliación denunciada por el autor, es nombrada “alternativa a la liberación”. Esta visión nace en 1985 cuando el presidente de la CELAM sugiere que el tema principal de la teología en América Latina no era el tema de la liberación sino que debiera ser el de la reconciliación. Ante esto, Schreiter (1998) expone que la liberación es una condición de la reconciliación y no debe suplantarse una por otra.

La liberación no es una alternativa a la reconciliación, sino un requisito previo para la misma. El llamamiento a la reconciliación no suple la necesidad de liberación; la demanda de liberación se plantea con la intención de allanar el camino hacia la reconciliación. (Schreiter, p.41)

Una tercera significación incorrecta de la reconciliación es la que la presenta como "proceso administrativo". Schreiter sustenta que esta forma confunda la reconciliación con la mediación de conflictos, en la que un mediador experto hace de conciliador entre las partes en conflicto, exponiendo que sus diferencias pueden ser negociadas, proponiendo de antemano que la negociación supone la legitimidad de los intereses y la necesidad de renunciar a algunos de ellos con el fin de reconciliar. Desde este enfoque,

La reconciliación es el resultado de un proceso impuesto, en el curso del cual, y con la ayuda de un mediador experto, la partes en conflicto pueden llegar a reconocer que sus diferencias en torno a las cuestiones que las enfrentan son reflejo de valores e intereses contrapuestos que deben ser negociados. (Schreiter, 1998, p.45) 
Por otro lado, Schreiter defiende que aunque la reconciliación no sea el vocablo más mencionado en la Biblia, si es un tema trasversal de la misma, un asunto que se encuentra en el trasfondo de las escrituras en sus distintos libros, sobretodo en el Nuevo Testamento. Jesús marca una ruptura frente a la tradición del Antiguo Testamento, que contiene la concepción de un Dios inmisericorde y un contexto divino en el que no se contempla la salvación, sino solamente el castigo por la comisión de los pecados. La misión de Jesucristo salvador es precisamente posibilitar el perdón de los pecados para que la reconciliación sea posible. Es aquí donde la Iglesia cumple un lugar central como autoridad y comunidad espiritual, en el que se realiza el sacramento de la reconciliación a través de los momentos expuestos con anterioridad.

Entonces, haciendo referencia al segundo punto de vista desde el cual se puede entender la reconciliación en la teología, Sobrino (2003) expone el papel de la Iglesia diciendo que,

En términos formales, y siguiendo la lógica paulina, a la Iglesia le toca corporeizar, dar cuerpo histórico a Cristo, para incorporarlo a la historia. Eso significa, en nuestro lenguaje, hacer que Cristo - y su Dios - "principien" realidades históricas; en este caso, que los cristianos seamos dispensadores del ministerio de la reconciliación. Todo lo que la Iglesia haga en favor de la verdad, de la justicia, del perdón y del modo de proceder de las bienaventuranzas, es su máximo aporte a la reconciliación. Se trata de ayudar a dar pasos históricos, reales por tanto, que encaminan a esa utopía. (parr.26)

Se tiene que, en la teología de corte cristiana, se comprende que el mal se manifiesta en la comisión de los pecados, y son estos los que deben ser perdonados por Dios para que la humanidad se reconcilie hacia una vida divina con Dios y entre los hombres en comunidad. El perdón es un don de Dios que ofrece a sus hijos para que estos vuelvan a él y participen de su gracia divina. De todos modos, es importante señalar que con la llegada de Jesucristo el mensaje del perdón cobra un lugar terrenal, en la medida en que el hombre tiene asimismo la capacidad para perdonar a su hermano, pues dice Jesús que, cómo quiere el hombre recibir el perdón de Dios si no es capaz de perdonar al prójimo. Por lo tanto, la reconciliación también es entre los hombres, partiendo de su voluntad como seres humildes y misericordiosos, libres y arrepentidos, dispuestos a la confesión, la penitencia y la satisfacción (reparación) de los daños. 


\subsection{Categorías fundamentales para la reconciliación desde la filosofía contemporánea}

A pesar de que la tradición filosófica aporta algunos elementos para la comprensión de la reconciliación, sobre todo desde la filosofía política, el interés del presente se centra en la reconciliación de estados de violencia y conflicto como los vividos en la actualidad, que requieren un estudio riguroso y preciso de las distintas dimensiones de abordaje. Por lo tanto, se tendrá en cuenta la filosofía de posguerra en este capítulo, para dar a conocer esas categorías fundantes del concepto de reconciliación contemporánea. Según el Jesuita Manwelo (2009), la filosofía política clásica poco se preocupó por el tema de la reconciliación, porque

La reconciliación es un tema que conlleva una fuerte connotación religiosa, sobre todo cuando por reconciliación se sobreentienden tanto las nociones de perdón como de conversión de los corazones. La filosofía política tiene por objeto el examen de las estructuras económicas, políticas y jurídicas con el objetivo de una buena sociedad. En ese contexto, el tema de la reconciliación, concebido en un sentido esencialmente religioso y/o de relaciones interpersonales, poco tiene que ver con el acercamiento esencialmente estructural de la filosofía política. (p.18)

Para este autor, el tema de la reconciliación como problema de la filosofía política aparece propiamente con la obra Teoría de la justicia de John Rawls publicada en 1971, y es precisamente una respuesta a la convulsión de un mundo globalizado, pluralista y post conflictual. Según Manwelo (2009), la Teoría de la justicia bien pudo haberse titulado Teoría de la reconciliación, ya que lo que ofrece Rawls es una propuesta fundamentada de las formas como la humanidad podría convivir en un mundo pluralista que ha estado marcado por fuertes conflictos religiosos, políticos, económicos y armados. Aparece entonces la reconciliación como un problema social producto de las diferencias en la forma de vida de los distintos grupos sociales a nivel global, y Rawls lo enmarca en el tema amplio y diverso de la justicia. La reconciliación desde Rawls sería el desafío de las sociedades actuales para convivir desde la tolerancia y la diversidad. La clave en Rawls es la dialéctica tolerancia/justicia.

En filosofía política, la cuestión de la reconciliación se ve así estrechamente unida a la de la justicia. Este es el lugar común por excelencia para reconciliar a los distintos individuos y también 
a los distintos pueblos y naciones. En otra obra, El Derecho de Gentes, Rawls desarrolla los principios de justicia que deben reconciliar a las distintas naciones del mundo. Es en este contexto donde Rawls declara que la justicia es la "primera virtud de las instituciones sociales" si queremos promover la paz y la estabilidad social. Entendemos también porqué Aristóteles y, tras él, Santo Tomás de Aquino, antes que Rawls, declarasen que la justicia es la "madre de todas las virtudes"; en ella se resumen todas las demás virtudes. En otras palabras, sin justicia, cualquier otra virtud, incluyendo la reconciliación, carecería de sentido. En cambio, gracias a la justicia, las otras virtudes se dan por añadidura. (Manwelo, 2009, p.19)

Desde este perspectiva, la reconciliación deriva, no necesaria, pero sí únicamente, de la justicia. En Rawls, la justicia es el elemento base a partir del cual se posibilita la reconciliación de las naciones, atendiendo a que su reflexión se circunscribe en un plano global de comprensión política.

Es importante señalar que el convulsionado siglo $\mathrm{XX}$, registra por lo menos tres fenómenos bélicos que posicionan el tema de la reconciliación en el escenario académico y gubernamental, en la medida en que estos se manifiestan como contradicción de los logros jurídicos y culturales obtenidos por la humanidad en este momento de un pregonado desarrollo civilizatorio, a saber, las dos guerras mundiales, las dictaduras y los regímenes autoritarios y fascistas (tanto latinoamericanos, como africanos y europeos), y la emergencia de los conflictos internos en los estados emergentes o en estados consolidados. Estos fenómenos son el escenario en el cual cobran relevancia tanto en las ciencias sociales, como en la filosofía, especialmente en la filosofía política, la pregunta por las transiciones democráticas, la reconciliación, la justicia transicional, los derechos de las víctimas, la memoria, y se renuevan viejas cuestiones en torno a la paz, la justicia, la verdad, el perdón y la dignidad humana. Dichos aspectos adquieren un carácter tanto ético, como político (y en algunos filósofos un carácter ontológico y epistemológico), siendo que se inscriben en la pregunta general por la organización social de los sujetos en distintos niveles de contexto, local, regional, nacional, internacional, mundial, global, y en las implicaciones y exigencias éticas y morales para la resolución de los conflictos y la convivencia civil (entre otras cuestiones). 
Las guerras del siglo XX europeo, el desarrollo de la filosofía latinoamericana y la emergencia de los estudios culturales y subalternos, entre otras corrientes de pensamiento, configuran el escenario político y filosófico para el planteamiento a una diversidad de propuestas críticas frente al orden social, local y mundial, establecido. Así mismo, la terminación o el anhelo por la terminación de los conflictos armados, de las distintas guerras y expresiones de violencia social y política, plantea la necesidad de analizar y describir reflexiones y propuestas tanto científicas como filosóficas para la superación de los conflictos, y para asumir las transiciones sociales que estos suponían.

De otro lado, fenómenos como la globalización mundial y su consecuente encuentro o choque de culturas -en los que se descubre, se conoce, se identifica o se avizoran desde distintos lugares diversas culturas, y por tanto, múltiples formas de ser, de estar, de habitar-, impulsaron un despliegue filosófico en torno a la pregunta renovada por la convivencia, el pluralismo, la diversidad, la multiculturalidad, las relaciones internacionales y el diálogo, que en alguna instancia tienen como trasfondo la cuestión de cómo deben relacionarse los hombres y sus distintas instituciones entre sí, para conservar un estado de paz, o bien, como superar en medio de la globalización, los diversos y complejos conflictos que se dan al interior de los estados y entre estos. Y en este escenario de guerra y globalización, que se registra la pregunta por la reconciliación, una vez ésta se desteta del amparo teológico, y comienza a perfilarse y estudiarse como problema social y político. Y es una pregunta que se plantea tanto desde la filosofía política como desde la ciencia política y el Derecho, propiamente en el marco de la resolución de conflictos y la teoría de la democracia, y de la justicia transicional, respectivamente.

Volviendo al contexto bélico del siglo XX, en algunos casos, la filosofía fue el resultado de la expresión inteligente y dolida, siempre vivencial e histórica de víctimas de estas guerras, como es el caso de H. Arendt, Th. Adorno, E. Levinas, entre muchos otros. Sus obras son el resultado de una reflexión experiencial de traumas profundos causados por hechos violentos, de la violencia social y política que comportan acontecimiento como la segunda guerra mundial y el intento de exterminio a los judíos, el nacionalsocialismo, entre otros. Este hecho ya de por sí constituye un valor sustancial a la decisión de acudir a algunos de los filósofos abordados a continuación y sobre todo, en el capítulo segundo, pues son voces vivas de guerras, 
sobrevivientes de estas, que aportan no sólo una reflexión inteligente al problema de la reconciliación, sino sobre todo, una reflexión situada.

La reconciliación como problema filosófico, se inscribe necesariamente en un momento de crítica a la razón occidental y del valor que se le da en la Modernidad, ya que ésta (la razón occidental/instrumental) desvirtúa otras dimensiones fundamentales del hombre como las emociones, lo indecible, lo místico, lo sagrado y lo silenciado, esferas todas que forman parte de la concepción de reconciliación que se pretende desarrollar, como categoría amplia, multidimensional y compleja del ser humano en sociedad y en el mundo natural. La crítica se presenta en dos vías; por un lado, se dirige a la historia como construcción humana e intelectual $\mathrm{y}$, por otro lado, a la idea de la razón como fuente única de conocimiento, ficcionalmente blindada de mal. Por lo tanto, a pesar del privilegio académico y social que ha tenido la historia, con los hechos violentos ocurridos en el siglo XX principalmente, algunos filósofos han erigido una crítica al sentido, propósito y la forma de la filosofía de la historia, denunciando las complicidades que abarca y las voces que ha aceptado acallar.

En este sentido, el tema de la reconciliación en la filosofía puede abordarse desde lo que se ha denominado la filosofía de la memoria, un enfoque que ha sido reconstruido por autores y pensamientos para abordar, entre otros, el tema de la memoria como reacción crítica de la historiografía y la filosofía de la historia, bajo el argumento de que la historia es la versión cómplice de quien ha actuado como ofensor, opresor, victimario, etc., dejando ausentes las voces de las víctimas de sucesos trágicos del devenir humano. La filosofía de la memoria es un enfoque, así como un apuesta moral por edificar una visión de la filosofía que se haga liberadora. ¿Liberadora de qué? Del dolor, del sufrimiento, del silenciamiento, de la ausencia y de las utopías de aquellos negados en la guerra, en el horror y en la historia. Se trata de hacer recuerdo consciente y salvífico de las florecillas pisadas por la historia por el bien del progreso, a que se refiere Hegel. Vale la pena en este punto traer a colación la tesis número 9 del filósofo Walter Benjamín (1973) que nos expone bellamente su idea de progreso y que arroja elementos valiosísimos para comprender el asunto de la historia y la memoria. 
Hay un cuadro de Klee que se llama Angelus Novus. En él se representa a un ángel que parece como si estuviese a punto de alejarse de algo que le tiene pasmado. Sus ojos están desmesuradamente abiertos, la boca abierta y extendidas las alas. Y este deberá ser el aspecto del ángel de la historia. Ha vuelto el rostro hacia el pasado. Donde a nosotros se nos manifiesta una cadena de datos, él ve una catástrofe única que amontona incansablemente ruina sobre ruina, arrojándolas a sus pies. Bien quisiera él detenerse, despertar a los muertos y recomponer lo despedazado. Pero desde el paraíso sopla un huracán que se ha enredado en sus alas y que es tan fuerte que el ángel ya no puede cerrarlas. Este huracán le empuja irreteniblemente hacia el futuro, al cual da la espalda, mientras que los montones de ruinas crecen ante él hasta el cielo. Ese huracán es lo que nosotros llamamos progreso. (parr.9)

Las tesis de la historia de Benjamín y la crítica que allí se plantea a la filosofía de la historia y a la idea progreso, constituyen una apertura filosófica para abordar el tema de la memoria y para fundamentar una crítica a la civilización occidental desde su mismo contexto vivencial retratado por el filósofo. Benjamín (1973) y la corriente de la teoría crítica, señalan que la violencia sistemática, planificada y desmedida, que se supone como un error o desvío en la cultura occidental, no es tal, no representa algo externo a la esencia de una cultura y un pensamiento, sino que por el contrario, es un elemento constitutivo de dicha cultura. La cultura occidental es violenta en su ser. Los excesos de la razón son parte de sí, y lo irracional que manifiesta en sus actos, producto de su exaltación de la razón como forma máxima y privilegiada de conocer, son el resultado de la manifestación de su esencia.

Lo anterior se constituye en una fuerte crítica a la estabilidad de la cultura occidental, pues se considera a esta como portadora de un mal absoluto que se evidencia con crueldad en las violencias que definen su legado. Avanzando, para Benjamín, la historia se presenta como un proceso mesiánico del tiempo actual en el que se rememora. La rememoración es el acto a través del cual en el presente, el pasado cobra actualidad, donde el pasado ya no es un pasado clausurado, sino que es un tiempo con posibilidad, con vigencia. Benjamín (1973) denuncia que la historia, como se ha elaborado, hace parte de una intencionalidad de justificar y mantener el statu quo de los que llamaríamos los vencedores. En este sentido, la visión lineal de la historia ha funcionado como un analgésico cruel frente al dolor padecido. 
Articular históricamente lo pasado no significa conocerlo «tal y como verdaderamente ha sido». Significa adueñarse de un recuerdo tal y como relumbra en el instante de un peligro. Al materialismo histórico le incumbe fijar una imagen del pasado tal y como se le presenta de improviso al sujeto histórico en el instante del peligro. El peligro amenaza tanto al patrimonio de la tradición como a los que lo reciben. En ambos casos es uno y el mismo: prestarse a ser instrumento de la clase dominante. En toda época ha de intentarse arrancar la tradición al respectivo conformismo que está a punto de subyugarla. El Mesías no viene únicamente como redentor; viene como vencedor del Anticristo. El don de encender en lo pasado la chispa de la esperanza sólo es inherente al historiador que está penetrado de lo siguiente: tampoco los muertos estarán seguros ante el enemigo cuando éste venza. Y este enemigo no ha cesado de vencer. (Benjamín, 1973, parr. 6)

En el proceso de revisión crítica está inserta la filosofía en general; de ahí que el filósofo alemán Theodor Adorno vislumbre un camino para darle salida a la encrucijada en que la disciplina ha quedado envuelta luego de las tragedias vividas recientemente en Europa (primera y segunda guerra mundial). Esa encrucijada se refiere a una pérdida de sentido, en la medida en que los avances reflexivos se ven negados por los hechos de guerra. La filosofía no tiene cómo explicar desde sus preceptos de humanidad, los actos calificados de inhumanos que deshumanizan al ser. Del mismo modo, el privilegio casi exclusivo que se otorga a la razón como esencia y posibilidad del ser, demerita y excluye otras dimensiones del hombre tan significativas como aquella: la emocionalidad y el simbolismo. En este contexto, propone Adorno que la filosofía es posible si recobra la experiencia en su construcción; frente a la cultura habrá que darle lugar a las formas y sujetos silenciados por la justificación que opera en la pretensión de universalidad de un espíritu que, en su camino de encuentro y plenitud acepta el sacrificio de los avatares de la historia. La filosofía deberá reconciliarse con formas del saber y tipos de conocimiento que la ilustración dejó en el silencio y el olvido por la confianza absoluta y exclusiva en la razón como fuente de conocimiento.

De la mano de la reflexión de Adorno, la filosofía se debe a la tarea de abrir el espectro de posibilidades, pues el enclaustramiento en una pretensión abstracta de conocer, la ha alejado del ser mismo, del hombre, de las situaciones que van perfilando el tiempo y el espacio. La experiencia recobra importancia en el pensamiento crítico, ya que se parte no de supuestos 
abstractos, sino de realidades concretas, de lo que ha acontecido, de lo que se siente, de la manifestación del ser, del mundo, del ser en el mundo. La comprensión social deberá erigirse entonces, a partir de un conocimiento que respete las dimensiones del individuo y de los grupos sociales, sin subvalorar los sentimientos, las emociones, lo que se ha denominado el espectro pasional del hombre, ya que el descrédito que han tenido estos elementos por parte de los movimientos modernizadores, ha sido parte constitutiva de la reducción a que se ha sometido el hombre y que ha contribuido a permitir la distancia con el Otro que conduce a su negación.

Es precisamente en este punto donde cobra gran relevancia el pensamiento del filósofo lituano Emmanuel Lévinas y el desarrollo de la categoría de 'alteridad', que se enmarca en el proyecto de reconstrucción ética de la filosofía y el hombre de posguerra. Al respecto, podemos señalar brevemente que, el Otro -como sujeto reconocido con carácter de igualdad en términos de humanidad- puede evocar distintas posiciones, de las cuales queremos mencionar las de responsabilidad, interpelación y reconocimiento que se sintetizan en la intersubjetividad, a partir de lo cual, siguiendo la propuesta de Lévinas, la ética se constituye en la filosofía primera y la conciencia del individuo es conciencia moral. Pero, ¿de qué tipo de responsabilidad, de interpelación y de reconocimiento estamos hablando? Lévinas (2000) comprende la responsabilidad desde la alteridad "como responsabilidad para con el Otro, como responsabilidad con el otro, así pues, como responsabilidad para lo que no es asunto mío o que incluso no me concierne; o que precisamente me concierne, es abordado por mí como rostro" (p.78).

Lévinas destaca la claridad de que se trata de una responsabilidad para con el otro, definiendo el sujeto al cual se dirige el sentimiento y la acción concreta. Se trata de una conciencia de compromiso con el otro, asumiéndose el yo como sujeto y el otro igualmente, como sujeto. Los pensamientos y las acciones de cada quien deben ser conscientes de las posibles consecuencias que traigan para los demás. Ser responsable desde la alteridad supone relaciones intersubjetivas en la que otro existe como lugar imprescindible en la definición de uno mismo. Llama especial atención el enfoque de Lévinas que argumenta que la responsabilidad a la que se refiere es con aquello que no me concierne. Y este el máximo punto ético del giro frente a la filosofía moderna, pues aparece lo otro como parte del yo a través de la responsabilidad, cuando el individuo, la libertad del yo y la autonomía habían ocupado un espacio central y fundante en las reflexiones 
filosóficas occidentales. Entonces ahora no es el individuo centrado en sí y en su búsqueda de autorrealización por medio de la individualidad, sino que hay un nuevo imperativo categórico donde aparece el otro constitutivo del yo.

De este modo, tenemos que el presupuesto base de la responsabilidad con el otro es el reconocimiento. $\mathrm{Y}$ este reconocimiento es entre sujetos; un sujeto reconoce a otro sujeto en igualdad de condiciones desde la voluntad y la libertad que a ambos compete. En la medida en que el yo reconozca al otro como sujeto desde el sí mismo de este, aquel estará en la posición de asumirlo como sujeto de su responsabilidad. Es clave dar cuenta de que se trata de reconocimiento de sujetos, pues también podría darse un falso reconocimiento, identificando al otro como objeto y negando por tanto la condición de reciprocidad en el ser humano. De manera que ver el valor que cada quien tiene por sí mismo es el enunciado que nos aporta la categoría del reconocimiento. Y este puede ser desde el rostro del otro que nos interpela.

La interpelación es una categoría que tiene mucho que ver con la reconciliación, sobre todo desde la mirada de las víctimas. Se entiende que el rostro de las víctimas, del dolor y el sufrimiento, nos interpela a través de su mirada, de su grito, de sus silencios, desde las distintas formas de lenguaje que puede expresar su emoción. Es la mirada que nos recuerda la responsabilidad que tenemos para con ellas, y lo que nos cuestiona sobre nosotros mismos, sobre si somos o no seres intersubjetivos que captamos la existencia o en algunos casos (como en los asesinatos) la no existencia del otro. Cuando tenemos de frente el rostro del otro y cuando le reconocemos como sujeto, podemos asemejar su condición desde su sí mismo a la nuestra, pues en contextos de violencia más específicamente, pero incluso en escenarios de paz, lo universal entre sujetos es el dolor y la vulnerabilidad ante la posibilidad.

Por lo tanto, la interpelación no es una súplica o petición de ayuda, sino que es el rostro que nos recuerda nuestra condición de sujetos igualmente vulnerables ante la voluntad y el despliegue de la violencia que destruye, que niega de facto cualquier intuición o sentido de la alteridad. Igualmente la interpelación no es sólo de la víctima, ni está únicamente dirigida al victimario, sino que se orienta al conjunto de la sociedad que ve y vive el conflicto armado, como espectador o como implicado en el mismo desde una u otra posición de sujeto. 
Hasta aquí con la categoría de alteridad. Avanzando en otro sentido, para el filósofo español Manuel Reyes Mate, la reconciliación es uno de los dos discursos posibles sobre las víctimas, siendo el otro el de la paz. Aduce que la paz ha sido tratada por lo político y que la reconciliación ha quedado relega al orden moral y religioso, criticando el escape que le da la política a dicho proceso. Para Reyes Mate (2006)

La reconciliación, (...) es la convivencia en comunidad. El acento se pone en la sociedad, en una sociedad dividida, rota por conflictos internos. Hablar de reconciliación es tanto como plantear la superación de los conflictos, la sutura de los desgarramientos entre unos y otros. Aquí importa algo más que la ley pues con la ley no se consigue vencer odios ancestrales o divisiones que escapan a todo análisis racional. Si ha habido un crimen, por ejemplo, se ha roto la convivencia real y esta no se recompone haciendo caer el peso de la ley sobre el asesino. Para restaurar la convivencia el asesino debe reconocer su falta y la víctima (y la sociedad), perdonarle. (p.106)

Esta sería una postura mesiánica, fundamentada en la apuesta del autor por la justicia de las víctimas y la memoria como puntos de partida para dicho proceso. Dice Reyes Mate (2006) que,

Aquí la "restitutio in integrum" tiene un sentido nada restrictivo. Se trata del derecho a la felicidad de todos y cada uno, aquí y ahora. Evoca una universalidad en la que nadie está re-presentado por otros, sino cada uno presente, de suerte que la felicidad del nieto no justifica la infelicidad del abuelo, ni el bienestar de los unos explica el malestar de los otros; se reconoce a cada cual su derecho a la felicidad y todo están presentes. (p.109)

Esta postura pone en el centro de la reconciliación, la justicia y la memoria de las víctimas, abriendo el debate sobre las posibilidades de la justicia anamnética y los alcances y funciones de la memoria en los procesos pos conflictuales. Para empezar habrá que decir que la justicia anamnética (de la memoria) parte de la experiencia de injusticia, de la exposición del daño objetivo, y por lo tanto, parte de la víctima y no del delito. Desde la concepción de irreparabilidad del sufrimiento, se sabe que este no prescribe. Esta justicia aboga por tener presente la significación de la muerte, de darle significado a lo acontecido, al dolor padecido y a 
la experiencia de la víctima, donde se presenta un giro en términos éticos, pues sobre el victimario recae la responsabilidad moral de sus actos.

La justicia anamnética es la justicia del ausente, una justicia de la reparación, de carácter reconstructiva que busca recomponer el bien común que todo crimen destruye. Implica así mismo asumir una responsabilidad histórica, donde las culpas se heredan. Y por último, aboga por una memoria salvífica, se salva el sufrimiento del pasado. Entonces para hablar de memoria y de justicia desde las víctimas hay que romper con la lógica lineal de la historia de la que se hablaba en un principio, ya que el pasado cobra un lugar privilegiado como epicentro de juzgamiento. En la justicia de las víctimas es imprescindible asumir el dolor y la injusticia sin límites temporales, porque lo que importa es reconocer todo el valor y sentido de la experiencia de sufrimiento.

Por consiguiente, para indicar formas de frenar y reparar en algún grado las injusticias, como principio de justicia, debe estar en el centro de la discusión la memoria, considerada como un ejercicio individual y colectivo de reconocimiento y significación del sufrimiento y la injusticia del pasado que se actualizan de manera consciente en el presente. Este proceso sucede como reacción a las desigualdades que han ido determinando o condicionando las relaciones humanas en una época o momento determinados, y pretende re significar ahora desde la mirada de la víctima, del oprimido, del vencido por otros y por la historia, el sentido de sus vivencias, del dolor, de la injusticia, denunciando la violación de sus derechos y reivindicándolos.

Otro asunto desde el cual se aborda la temática propuesta, es el que trabaja el mismo autor en el libro Memoria de Auschwitz. Actualidad moral y política, particularmente en el capítulo sexto, abogando por una justicia de las víctimas que corresponde a lo que allí de trabaja como la cultura reconstructiva. Al respecto señala Reyes Mate (2003) que

La cultura reconstructiva se llama así porque la injusticia es vista como una acción que destruye una relación, que la justicia debe reconstruir. Esta cultura o sensibilidad tiene múltiples manifestaciones no necesariamente vertebradas. 
Existe, por un lado, una ética reconstructiva que se presenta como una síntesis de narración y argumentación o, si se prefiere, de aproximación del ideal universal y abstracto de la justicia discursiva a la solidaria real con sujetos individualizados (Ferri, 2001). Pero quizá sea el derecho, sobre todo el penal, el campo en el que más se ha desarrollado. Lo que caracterizaría al derecho animado por esta cultura sería la sustitución del vínculo entre justicia y castigo por el de justicia y reparación de las víctimas. Ahí se produce un desplazamiento de acentos que va de la intencionalidad del acto al prejuicio objetivo, como en la justicia de los antiguos. (p. 242-243)

Pero para adentrarnos en ese mundo de la justicia en clave de reconciliación, de lo pos conflictual, debe haber un proceso profundo de verdad y de perdón, y aparece la propuesta de Jacques Derrida de confesar lo inconfesable y de perdonar lo imperdonable como presupuestos de un verdadero "vivir juntos". Anota Derrida (2000) en una conferencia presentada en París en diciembre de 1998, ocasión del tema del "vivir juntos", su hipótesis sobre el momento actual, aduciendo que:

Pues bien, hoy, y digo hoy, para los llamados contemporáneos, para quienes se piensa que viven juntos, en una supuesta sincronía, el ahora histórico de un tiempo dado, hoy, pues, en el mismo mundo, y ante las responsabilidades (éticas, políticas, jurídicas, religiosas, y otras) a las que apela eso que llamamos de manera tan oscura, en nuestra lengua, "vivir juntos", digo que una cierta confesión se presentaría como el primer mandamiento.

No una confesión cualquiera, sino una confesión singular, inaudita, improbable, una confesión que, antes y más allá de toda falta determinada, declara ante el otro lo inconfesable. Pues confesar lo que parece fácil confesar, confesar lo confesable, reconozcámoslo, una cosa así no sería confesar. Confesémoslo. La confesión, si la hay, debe confesar lo inconfesable, y en consecuencia, declararlo. La confesión tendría que declarar, si fuese posible, lo inconfesable, es decir, lo injusto, lo injustificable, lo imperdonable, hasta la imposibilidad de confesar. Del mismo modo, perdonar sólo lo que es perdonable, venial, algo así no sería perdonar. La confesión, si la hay, tiene que confesar lo inconfesable, y el perdón, si lo hay, tiene que perdonar lo imperdonable, y en consecuencia, hacer lo imposible. Si tal confesar es la condición del "vivir juntos", lo que esto requeriría es hacer algo imposible. (p.18) 
La reconciliación, ese nuevo "vivir juntos", tendría como primer mandamiento el confesar lo imposible. La verdad como desafío para la sociedad, para el hombre y su sufrimiento, para el hombre y su vergüenza, o para el hombre y su indiferencia ante lo sucedido, ante lo ejercido. La imposibilidad como único camino de un verdadero vivir juntos es el reto que plantea Derrida, tanto en el hecho de la palabra sincera (la confesión), como en el acto de entrega y desprendimiento de ofensas (el perdón). ¿Cómo es posible lo imposible? ¿Cómo vivir juntos? ¿Cómo vivir juntos reconstruyendo desde lo imposible, posibilidades de existencia? ¿En caso de ser posible lo imposible, está la sociedad en la capacidad de conocer las verdades confesadas y asumir el perdón requeridos para un nuevo vivir? Estos son algunos de los problemas que se plantean desde la perspectiva filosófica señalada y que serán objeto de estudio en el capítulo siguiente.

\subsection{Formas políticas de la reconciliación}

Desde el ámbito pragmático de la política, la reconciliación ha sido vista como el resultado de un proceso de acercamientos y acuerdos entre actores enfrentados en un conflicto armado. Incluye un proceso de negociación y solución del conflicto. La resolución política de un conflicto interno que como el colombiano, es la expresión de la lucha por el poder político, supone la negociación entre dos actores, el Estado y un grupo armado al margen de la ley. El Estado busca mantener un cierto orden que teóricamente se fundamenta en el mandato legal de la Constitución (imperio de la Ley), que consagra a su vez el uso legítimo de la fuerza, el control territorial y el ejercicio de la soberanía política (principios del Estado- Nación). De otra parte, el grupo armado al margen de la ley disputa al Estado el ejercicio del control y la dirección de los asuntos públicos, poniendo en vilo la soberanía estatal. A grandes rasgos, el conflicto armado que involucra, se nutre y afecta distintas dimensiones del ordenamiento social de una población, es una contienda armada, lingüística, económica, política, simbólica y cultural, por el control territorial, poblacional e ideológico en un determinado espacio-tiempo, en donde, del mismo modo, se pretende eliminar el monopolio de la acción e influencia del rival. 
El ejercicio del poder armado y político por parte de un grupo armado constituido al margen de la ley, denuncia el ejercicio del poder del Estado, poniendo en jaque la posibilidad de gobierno de éste sobre determinado territorio, y dejando de manifiesto la inestabilidad y vulnerabilidad de las instituciones públicas y los límites de las estructuras y funcionarios del poder constituido. Ahora bien, la concepción de la reconciliación, desde el punto de vista político, se ha reducido en gran medida a la postura negativa de la paz, en la que predomina una visión de orden que queda sujeta a la voluntad del gobernante.

Esta postura se enmarca en la concepción política Schmittiana, en la que la esencia de lo político se fundamenta en la relación antagónica de amigo- enemigo. El Estado aparece como la unidad política por excelencia en la que se demarcan las fronteras administrativas, jurisdiccionales, judiciales y soberanas. Funciona como frontera, a la vez que delimita los marcos de la paz y de la guerra: al interior se conserva un ordenamiento pacífico en el marco del sistema político democrático, y hacia el exterior se puede o no hacer la guerra, conservando el carácter soberano de uno y otro Estado, siendo mediadas y definidas sus normas por el derecho internacional. La guerra entre Estados se nutre y recrea a la vez una imagen y contenido de creación del enemigo; asimismo, la guerra se puede superar con un acuerdo de finalización de la misma, que generalmente se transa con una amnistía, denotando la relativización de la enemistad en sí. Define Schmitt (1932) que, "la distinción política específica, aquella a la que pueden reconducirse todas las acciones y motivos políticos, es la distinción de amigo y enemigo" (p.56). Y más adelante expone que,

El sentido de la distinción amigo-enemigo es marcar el grado máximo de intensidad de una unión o separación, de una asociación o disociación. (...) [El enemigo político] Es simplemente el otro, el extraño, y para determinar su esencia basta con que sea existencialmente distinto y extraño en un sentido particularmente intensivo. En último extremo pueden producirse conflictos con él que no puedan resolverse ni desde alguna normativa general previa ni en virtud del juicio o sentencia de un tercero «no afectado» o «imparcial». (Schmitt, 1932, p.57)

Para Schmitt (1932), la resolución de los conflictos que emanan de la enemistad política, es posible sólo entre los participantes de la misma. Sería la decisión que proviene del reconocimiento de que el otro, el extraño, no representa un peligro para el orden y existencia del 
yo. Se podría comprender que la reconciliación política entonces, consistiría en la transformación de la definición y contenido de la enemistad hacia la amistad. Sería un tránsito hacia la amistad entre dos ex enemigos. El extraño dejaría de ser considerado extraño para constituirse en una relación de cooperación, solidaridad, acuerdo, en últimas de amistad política. Pero claro, existen conflictos que no se dan entre Estados soberanos, sino que se dan al interior de un Estado. Como el caso colombiano, la guerra, y por consiguiente la construcción social del enemigo se da dentro de las fronteras nacionales.

Enemigo es sólo un conjunto de hombres que siquiera eventualmente, esto es, de acuerdo con una posibilidad real, se opone combativamente a otro conjunto análogo. Solo es enemigo el enemigo público pues todo cuanto hace referencia a un conjunto tal de personas, o en términos más precisos a un pueblo entero, adquiere eo ipso carácter público. Enemigo es en suma host is, no inimicus en sentido amplio; [el polemios, no el echthros]. (Schmitt, 1932, p.58-59)

El enemigo político no tiene que ser enemigo en lo privado, y por lo tanto, la resolución del conflicto involucra más asuntos de estructura, que de subjetividades en sentido personalista. Pero no hay que tomar esto a la ligera, pues de todos modos la construcción del enemigo es un acto subjetivo, en el que un grupo decide cuál es ese otro que según aquel, representa una amenaza efectiva, real y progresiva a su proyecto político. Según Schmitt (1932), la experiencia práctica y discursiva de la política denota siempre una referencia hacia algo otro. Toda afirmación denuncia a la vez que afirma, señala a la vez que oculta. Y este juego está dirigido por ánimos de amistad y enemistad. Cuando se concentran los enfrentamientos partidarios al interior de un Estado, tan agudos como para concentrar un tipo de política interna en torno a los mismos, se da un caso, no de guerra entre Estados soberanos, sino que es el caso de una guerra civil.

[La] guerra civil es una lucha armada en el seno de una unidad organizada (que sin embargo se vuelve justamente por ello problemática). (...)Los conceptos de amigo, enemigo y lucha adquieren su sentido real por el hecho de que están y se mantienen en conexión con la posibilidad real de matar físicamente. La guerra procede de la enemistad, ya que esta es una negación óntica de un ser distinto. La guerra no es sino la realización extrema de la enemistad. (Schmitt, 1932, p.62-63) 
Entonces, así como la guerra supone la decisión política de efectuar un combate, y de decidir quién es el enemigo, la reconciliación, como transición a un estado de paz, consiste en la decisión política de que el enemigo deje de serlo. El antagonismo de la relación amigo/enemigo define la política en la medida en que se ésta constituye y expresa una tensión, como la posibilidad siempre real de que se desate un combate entre grupos humanos.

Lo anterior es un paradigma de la política, entendiéndola desde la concepción antagónica de las relaciones entre los hombres, pueblos y/o Estados modernos. Pero existe de otro lado, una visión pluralista de la política. Se trata de la propuesta teórica de la filósofa alemana Hannah Arendt, en la que se expone una forma original y creativa de comprensión de lo político. Para la autora, la política supone la capacidad humana de construir un tipo de relación social en la que se funden de manera posible la libertad, la individualidad y la pluralidad. La política es el espacio plural de interacción social que se constituye en el espacio público, el escenario de los encuentros donde confluyen los individuos y se reconfiguran los lugares de lo privado y lo público. "La política se basa en el hecho de la pluralidad de los hombres" (Arendt, 1997, p. 45).

Para Arendt es preciso hacerse preguntas sencillas y generales como ¿qué es la política?, cuando las respuestas que se tienen al presente no son suficientes y la tradición teórica o filosófica no logra ofrecer sentidos completos para los nuevos contextos. Entonces, habrá que pensarse qué es política en el contexto actual, cuáles son las categorías que la definen y cómo se da hoy día la manifestación de dichas categorías en prácticas individuales y sociales. La libertad se basa en la pluralidad, que constituye así mismo la condición humana. Y el espacio público se edifica con base a las libertades. La política denota la posibilidad del diálogo, el encuentro y el consenso. "La política trata del estar juntos y los unos con los otros de los diversos" (Arendt, 1997, p. 45).

Para ubicar un poco el asunto de la reconciliación en el orden político contemporáneo, se tiene que,

Como fenómeno político e internacional y en aras de facilitar el análisis de los llamados procesos de reconciliación, éstos se pueden enmarcar dentro del movimiento de transición a la democracia que Samuel Huntington (1993), denomina “tercera ola de democratización”. Denominación bajo la 
cual, el autor intenta explicar las razones que suscitaron en el período comprendido entre 1974 y 1990, una ola democrática en la cual alrededor de 30 países cambiaron de un régimen autoritario a un sistema de gobierno democrático. (Bueno, 2006, p.65)

La reconciliación se enmarca en el proceso amplio de las transiciones democráticas, que obedecen a distintos tipos de conflicto armado. Unos casos fueron las transiciones de regímenes autoritarios a regímenes democráticos, siendo tal el caso por ejemplo, de las dictaduras latinoamericanas. Y otro entramado de conflictos son los que tienen que ver con la definición de guerras civiles o conflictos internos, casos en los cuales la transición consiste precisamente en el cese de hostilidades, la firma de un acuerdo de paz entre las fuerzas del Estado y las fuerzas al margen de la ley, y el diseño y ejecución de políticas erigidas a partir de la justicia transicional.

La reconciliación en estos escenarios sería la apuesta por recomponer la confianza en las instituciones estatales, superar las cicatrices sociales que dejan los enfrentamientos y el escenario de la guerra, y recomponer el tejido social fragmentado en el orden normativo de la ciudadanía, los derechos humanos y la democracia. También se considera la posibilidad de que los grupos anteriormente enfrentados, puedan coexistir en un mismo territorio y de que la oposición política se ejerza con base en los principios del Derecho Constitucional y de las normas vigentes, y no a través de las armas y el ejercicio de la violencia política.

De forma esquemática, de otro lado, Uprimny y Saffon establecen una clasificación de tres formas de reconciliación que se sustentan en distintas comprensiones de la paz, el orden, la solución de conflictos y la convivencia social. La primera es una visión minimalista de la reconciliación, que se entiende como la tolerancia resignada u obligada entre grupos en conflicto. Esta concepción pone la paz por encima de todo precepto, una paz limitada al cese del fuego, que no se preocupa por las causas del conflicto, ni por la permanencia de las enemistades, desigualdades sociales y ausencias de reconocimiento social y político de ciudadanos. El fundamento es la paz negativa, esto es, la ausencia de actos o luchas violentas que se logra por la solución de los conflictos existentes. Luego,

En segundo lugar, existe una noción maximalista o fundamentalista de la reconciliación, que concibe que la paz duradera depende no sólo de que los individuos convivan pacíficamente y se reconozcan mutuamente como ciudadanos con iguales derechos y con capacidad para resolver sus 
diferencias a través de la discusión política, sino también de que se perdonen los unos a los otros, y demuestren sentimientos de simpatía, solidaridad, e incluso afecto para con los otros, incluso para sus victimarios. (Uprimny y Saffon, s.f., parr.8)

Y una tercera visión es la democrática, que propone la reconciliación como un escenario de posconflicto apto para el ejercicio activo de la ciudadanía, fundamentándose en el reconocimiento recíproco de los ciudadanos, con derecho a participar en la discusión y dirección de la política y los asuntos públicos, conservando el derecho a disentir y no estar de acuerdo unos con otros. La visión democrática de la reconciliación que defienden los autores, expresa una apuesta por la participación profunda de los ciudadanos en la reconstrucción del tejido social, desde las presencias y las ausencias, los acuerdos y los disensos.

De modo general, se podría decir que los fundamentos políticos de la reconciliación son la democracia y el Estado de Derecho. Sin embargo, es preciso ahondar entonces en la pregunta de qué es la democracia, por un lado, y cuáles son los principios del Estado de Derecho, por otro. Beristain (s.f.), doctor en Psicología y defensor de los derechos humanos de las víctimas, establece que,

Al hablar de una eficaz salida democrática en situaciones postconflicto, se deben tener en cuenta dos perspectivas: la de estructuras y procedimientos, que permite manejar los temas en conflicto que dividen a la sociedad; y el conjunto de relaciones fundamentales entre los grupos involucrados. En una sociedad, si las estructuras no son justas, no podrán desarrollarse esas relaciones entre los grupos. Y a la inversa, las estructuras no funcionarán adecuadamente, por muy justas que sean, si no existe un mínimo de cooperación entre los grupos. En este sentido, el compromiso democrático se orienta a buscar soluciones a las causas del conflicto, mientras que la reconciliación se dirige a las relaciones entre los que deben implementar las soluciones (Estado, políticos y población). (...)

La reconciliación, como recuperación de relaciones sociales fracturadas, necesita abordar la justicia económica y la participación en el poder político, dado que ambos aspectos están relacionados entre sí. La búsqueda de soluciones políticas a los conflictos no debe contemplar únicamente la dimensión armada o los efectos de la propia violencia o represión, pues en la base de los mismos existe un fuerte componente de marginación política y de conflictividad social asociadas a condiciones de pobreza y exclusión en amplias capas de la población. 
Esta perspectiva destaca que la reconciliación refuerza la democracia al fomentar una recuperación de las relaciones fundamentales necesarias para la implementación de los cambios. Según esto, así como puede existir en determinadas situaciones un argumento moral a favor de la reconciliación, también se da un poderoso argumento pragmático: relaciones funcionales positivas generan el ambiente favorable para el desarrollo de un buen gobierno, mientras que relaciones negativas socavan hasta el mejor sistema de gobierno. (p.15)

La reconciliación en los procesos pos conflictuales empieza a constituirse dentro del orden político programático de un Estado, en el que se reestructuran la institucionalidad pública, con la creación o modificaciones de funciones, cargos y direcciones que amplían, reducen o re direccionan el aparataje estatal. Entran en juego las políticas públicas de la reconciliación, la creación de programas institucionales y el abordaje de nuevas concepciones teóricas e ideológicas de organización de lo político y lo público. Estamos ante la mirada intervencionista del Estado que se reprograma en aras de asumir y desplegar su propia concepción de la reconciliación, limitado claro está, por los distintos actores y grupos de presión que ejercen control y dirección en las políticas estatales. Queda por resolver, si la reconciliación en términos programáticos, debe proyectarse por políticas estatales, políticas de gobierno o políticas públicas en el sentido radical del término.

La reconciliación como proyecto de transformación social operaría como un eje orientador de programas políticos y de políticas públicas específicas, traduciéndose en lineamientos y estrategias puntales de intervención social, que propenden a la institucionalización de normas, comportamientos y prácticas de resolución pacífica de conflictos, co-existencia y convivencia, en la promoción de procesos para el aumento de niveles de tolerancia, confianza y capital social en sociedades que han experimentado conflictividades de alta confrontación en períodos significativos de tiempo. (Herrera y Garrido, s.f., p.181)

Habrá que anotar que la reconciliación política será tan profunda o somera según la comprensión política y de la política de los actores en conflicto y que la misma sociedad manifieste y presione. Por ejemplo, si se enmarcan en el paradigma del realismo político (la política como actividad amoral), la reconciliación de hecho será irrelevante, y lo que se producirán serán acuerdos 
programáticos entre las partes armadas para la superación de la violencia y la consecución de paz del tipo negativo (ausencia de guerra). Mientras que, por otro lado, si se asume la política entendiendo la integralidad del hombre, como actividad que supone en sí misma la moral, y que busca la organización social en pro del bienestar de la comunidad política, y en un marco democrático, el goce efectivo de los derechos humanos y el ejercicio de la ciudadanía, es posible que se considere la reconciliación, en un escenario de posconflicto, como un medio y un objetivo imprescindibles de la sociedad y el Estado en su reconstrucción.

\subsection{La justicia transicional como escenario jurídico de la reconciliación}

En este apartado se presentará brevemente el abordaje de la reconciliación a partir de la concepción contemporánea de la justicia transicional, puesto que es en esta tradición donde se inscribe la historia reciente y actual del Derecho en la solución de conflictos armados como el que vive Colombia en el presente. La justicia transicional es un tipo de justicia alternativa que se ha implementado a partir de la primera guerra mundial en transiciones de un estado de guerra a un estado de paz, o en la transición de un régimen autoritario a un régimen democrático, como es el caso de las transiciones de los países de América Latina que padecieron gobiernos dictatoriales.

Los orígenes de la justicia transicional moderna se remontan a la Primera Guerra Mundial. Sin embargo, la justicia transicional comienza a ser entendida como extraordinaria e internacional en el período de la posguerra después de 1945. La Guerra Fría da término al internacionalismo de esta primera fase, o fase de la posguerra, de la justicia transicional. La segunda fase o fase de la posguerra fría, se asocia con la ola de transiciones hacia la democracia y modernización que comenzó en 1989. Hacia finales del siglo XX, la política mundial se caracterizó por una aceleración en la resolución de conflictos y un persistente discurso por la justicia en el mundo del derecho y en la sociedad. La tercera fase, o estado estable, de la justicia transicional, está asociada con las condiciones contemporáneas de conflicto persistente que echan las bases para establecer como normal un derecho de la violencia. (Teitel, 2003, p.2) 
De modo general, la justicia transicional es el conjunto de medidas jurídicas y administrativas que se disponen para tatar legados de abusos masivos de los Derechos Humanos y la comisión de crímenes de lesa humanidad. Se trata de la implementación de instancias jurídicas y políticas con las cuales se pretende conseguir el logro de la paz, de la justicia y la reconfiguración de la seguridad, así como la reorganización de la sociedad bajo los principios del Estado de Derecho, el enjuiciamiento de los perpetradores de violaciones de derechos humanos y la reparación de las víctimas de los crímenes de lesa humanidad que se cometieron durante décadas del conflicto armado interno. Al respecto, Uprimny (2006) explica que,

Los procesos de justicia transicional buscan, ordinariamente, llevar a cabo una transformación radical del orden social y político de un país, bien para reemplazar un estado de guerra civil por un orden social pacífico, bien para pasar de una dictadura a un orden político democrático. Especialmente cuando se trata de transiciones negociadas, cuyo objetivo es dejar atrás un conflicto armado y reconstituir el tejido social, dicha transformación implica la difícil tarea de lograr un equilibrio entre las exigencias de justicia y paz, es decir, entre los derechos de las víctimas del conflicto y las condiciones impuestas por los actores armados para desmovilizarse. (p.19-20)

Entonces, la finalidad de la justicia transicional es la garantía de los derechos constitucionales y la efectividad del Estado de Derecho, a través de un proceso social, político y jurídico de reconocimiento y garantía de los derechos de las víctimas con el fin de sentar las bases hacia la reconciliación nacional, la reconstrucción del tejido social y el logro de la confianza de los ciudadanos en las instituciones y agentes estatales. De ahí la importancia de la garantía de los derechos de las víctimas y el reconocimiento de estas dentro de un proceso transicional, pues las medidas efectuadas pueden contribuir al logro de los objetivos señalados, en la medida en que promuevan la satisfacción de las mismas.

Lo anterior parte del supuesto de que la violencia niega la dignidad de la víctima, la democracia y el libre ejercicio de la ciudadanía; profundiza la exclusión, la inequidad y la animalización del Otro. Un impacto profundo de la violencia es la pérdida de autonomía de la persona sometida a 
ella. Quien se encuentra sujeto a hechos de violencia, pierde el gobierno de sí mismo, no es capaz de ejercer autoridad sobre sí mismo.

Teniendo en cuenta lo anterior, un principio fundamental de la justicia transicional es la disposición de medidas jurídicas, políticas y económicas encaminadas a la garantía de los derechos de las víctimas a la verdad, la justicia, la reparación integral y la no repetición, declarados por la ONU, respaldados por el Derecho Internacional Humanitario y consagrados en la Declaración de las Naciones Unidas sobre los principios fundamentales de justicia para las víctimas de delitos y del abuso de poder, aprobada por la Asamblea General en noviembre de 1985. La jurisprudencia constitucional colombiana ha incorporado paulatinamente estas medidas, que reconocen los derechos de las víctimas y el deber del Estado frente a los mismos por acción u omisión en el conflicto armado.

Estas disposiciones se fundamentan en los principios de Joinet que constituyen la estructura del proyecto de principios básicos de los derechos de las Víctimas asumidas como sujetos de derecho. Joinet (1997) elaboró un informe sobre La cuestión de la impunidad de los autores de violaciones de los derechos humanos (civiles y políticos), ${ }^{2}$ en el que se contemplan estos derechos, su fundamento y las posibles vías para garantizarlos. Por un lado está el derecho a saber, que se establece en dos dimensiones, una individual que se refiere al conocimiento que tenga la victima de los hechos acaecidos y sus causas, y otra colectiva "que tiene su origen en la historia para evitar que en el futuro las violaciones se reproduzcan”. El Estado está obligado a promover el "deber de la memoria", que consiste en la conservación y divulgación de los hechos y situaciones ocurridas en medio del conflicto armado, pues "el conocimiento, para un pueblo, de la historia de su opresión pertenece a su patrimonio y como tal debe ser preservado".

El derecho a la justicia se refiere a dos asuntos puntuales: El derecho a un recurso justo y eficaz y Medidas restrictivas justificadas por la lucha contra la impunidad. El derecho a la reparación implica dimensiones individuales, generales y colectivas, y se establece en medidas de restitución, indemnización y readaptación. Y finalmente, el derecho a la garantía de no repetición

\footnotetext{
${ }^{2}$ Para consultar, el informe véase, http://www.derechos.org/nizkor/doc/joinete.html.
} 
que consiste en la adopción de medidas dirigidas a que no se repitan los hechos violatorios de derechos humanos.

Frente a la reparación, el informe contempla que,

En el plano individual, las víctimas, ya sean víctimas directas, parientes o personas a cargo, deben beneficiarse de un recurso eficaz. Los procedimientos aplicables deben ser objeto de una publicidad lo más amplia posible. El derecho a reparación debe cubrir la integralidad de perjuicios sufridos por la víctima. (Joinet, 1997)

Las medidas de reparación son:

a) Medidas de restitución (tendentes a que la víctima pueda volver a la situación anterior a la violación);

b) Medidas de indemnización (perjuicio síquico y moral, así como pérdida de una oportunidad, daños materiales, atentados a la reputación y gastos de asistencia jurídica); y

c) Medidas de readaptación (atención médica que comprenda la atención psicológica y psiquiátrica). (Joinet, 1997)

La garantía de los derechos está en manos del Estado, debido a la responsabilidad constitucional que tiene el mismo frente a los ciudadanos de propender por la paz nacional, promover las medidas necesarias para hacer posible la culminación del conflicto armado y garantizar los derechos de las víctimas. La responsabilidad del Estado comprende dos sentidos: la acción y la omisión. Por acción se entiende la violación directa de los derechos humanos por parte de las instituciones, agentes y/o fuerzas del Estado por un lado, y por otro, la complicidad y/o alianza con agentes externos al Estado en la misma situación. Por omisión se entiende la permisividad del Estado frente a los hechos violentos y la no garantía de los derechos de los ciudadanos. Así pues,

[L]a responsabilidad internacional del Estado se compromete a partir del momento en que deja él de cumplir una obligación internacional, independientemente de la verificación de falta o culpa de 
su parte, y de la ocurrencia de un daño adicional. Más que una presunta actitud o falla psicológica de los agentes del poder público, lo que realmente es determinante es la conducta objetiva del Estado (la debida diligencia para evitar violaciones de los derechos humanos). Se puede, así, ciertamente llegar a la configuración de la responsabilidad objetiva o "absoluta" del Estado a partir de la violación de sus obligaciones internacionales convencionales en materia de protección de los derechos humanos. Sobre dicha responsabilidad objetiva reposa el deber de prevención. (Corte IDH, s.f.)

Ahora bien, es necesario dejar en claro que la justicia transicional normativamente, va más allá de las medidas jurídicas o la alternatividad penal aplicada a los victimarios, y que su fundamento consiste en propiciar un escenario para una transición social de una situación de violencia masiva a la reconfiguración de la comunidad política en torno al Estado de Derecho. Esto significa que los ciudadanos y las instituciones se regirán por los principios y las normas constitucionales, como base jurídica del ordenamiento social. La justicia transicional hace especial acento en la reconstrucción de la confianza de los ciudadanos hacia el Estado, sus leyes e instituciones.

\subsection{La reconciliación desde la mirada de comunidades no occidentales en América Latina}

Existe una tradición diferente a la cultura occidental con su propia cosmovisión en América Latina, que resulta muy significativa a la hora de pensar un problema filosófico desde el continente. La referencia es lo que se ha comprendido a partir de distintas categorías, tales como la sabiduría indígena, el conocimiento ancestral, la filosofía amerindiana, entre otros, haciendo alusión al pensamiento de los pueblos originarios, sobretodo de lo que geo-culturalmente se conoce como Latinoamérica. Las fuentes para acceder al conocimiento indígena son variadas, y aunque no sea posible equiparar todas las culturas a una forma unívoca de pensar y sentir el mundo, si ha sido viable reconocer tendencias conceptuales y de significado entre pueblos, y a partir de ahí, trabajar con categorías que recogen y dan cuenta en términos occidentales de la razón indígena -con los límites propios de la hermenéutica misma-. 
Reconociendo la originalidad y fuerza de la sabiduría indígena, tanto en el entendimiento del ser humano, como en la visión universal del mundo, el presente apartado se propone dar cuenta de algunos elementos, categorías y sentidos que aportan a la construcción del concepto de reconciliación, desde la mirada de culturas no occidentales en el marco de lo mencionado con anterioridad. Nos moveremos para ello, de la mano de autores latinoamericanos que se han concentrado en el estudio del pensamiento indígena como base constitutiva de la filosofía latinoamericana, y a su vez de la aplicación del método fenomenológico en experiencias con autoridades y sabedores indígenas.

Para comprender el aporte de lo indígena y ubicarlo ampliamente en la reflexión filosófica, partimos de dos supuestos. Primero, lo indígena con toda su carga simbólica y existencial, provoca el reconocimiento de una cultura que en sí misma contiene toda una historia de comunidad, de organización social, de expresión humana, de formas de relación con el mundo o más bien en el mundo, que ofrece una alternativa e incluso una solución a los problemas sociales, económicos, políticos, culturales y hasta psicológicos, a las enfermedades que están destruyendo el organismo vivo de las actuales sociedades (Kusch, 1978), en las que una de las manifestaciones más visibles es el conflicto social y armado en Colombia, por citar un ejemplo.

Pensar lo indígena es pues, no sólo hacer un ejercicio de reconocimiento del Otro por el Otro, sino que supone sobretodo, reconocer-nos en la expresión de alteridad con ese Otro, que en Latinoamérica, hace parte de un Nosotros aún por descubrir y construir. Entonces habrá que considerar la reconciliación en lo indígena, no sólo desde los postulados que ofrezca el conocimiento ancestral, sino también desde la historia misma de los pueblos originarios y el conflictivo nacimiento del continente americano.

En segundo lugar, en un nivel epistemológico, la construcción del pensamiento indígena guarda una íntima relación con el sentir, con la emoción, el corazón y la trasmisión ancestral de sabiduría, a través de las plantas sagradas, la danza, el mambeo, la música y la tradición oral. Es fundamental reconocer que la sabiduría indígena se mide por el comportamiento de sus portadores y no tanto por la lógica interna de los escritos. Se podría decir que, saber y hombre 
son un mismo texto. Así pues, la palabra desde la cosmovisión y praxis indígena es creación, es magia, es todo un ritual de conocimiento y vivencia hacedora. La episteme, el conocimiento, la sabiduría amerindiana se fundamenta en la relación recíproca entre hombre y naturaleza, en una posible simbiosis entre ambos. Así mismo, la razón de la sabiduría es la óptima convivencia, coexistencia entre estos elementos, que desde la razón occidental están escindidos. Para el indígena la vida no es posible sin la Madre Tierra, y la razón de ser del hombre es cuidarla, conservarla, dar su lugar como posibilidad de vida, como dadora de vida y como vida en sí-misma, en la que se logra la conciencia natural.

Es fundamental señalar que dentro de dicha conciencia natural, el hombre ocupa un lugar de relacionalidad y no de centralidad, es decir, que se está en un juego de relaciones y no en una condición de superioridad. En la cosmovisión indígena recreada en el diario vivir de las comunidades y contenida en sus mitos, el hombre es parte integradora del entorno, no determinadora. Por consiguiente, se puede decir que los hombres no son ontológicamente superiores a los animales o las plantas, sino que son uno más dentro del orden cósmico, en el que cada ser o ente cumple una función constitutiva del todo. De ahí que se pueda desprender una ética en sentido amplio, pues el reconocimiento del otro se despliega de manera general, mostrando respeto por la diversidad y existencia del entorno.

En este orden de ideas habrá que indagar por el sentido de la interculturalidad, que más que el reconocimiento del otro como igual en términos valorativos, es la posibilidad de promover, a partir de la comprensión de formas de vida diferentes, una mirada más sana del hombre y del mundo, donde se supere la determinación dominadora de aquel sobre este o del hombre por el hombre mismo; Estermann (1998), en este sentido presenta que "el runa [hombre]... es un puente cósmico imprescindible... Como tal, tiene una función de mediación, pero no en un sentido 'lógico- representativo'; el hombre no 'recrea' el cosmos en forma conceptual, ni lo conoce de manera abstractiva y racional" (198).

El hombre cumple la función de preservar el mundo, de mediar con la sabiduría entre él y la naturaleza y lo que la compone. El diálogo y el lenguaje se convierten en elementos centrales de 
la manifestación del hombre en su función relacional. Estos componentes hacen frente al proyecto occidental y se hallan presentes en los distintos lugares donde la concepción andina por ejemplo, o amazónica aún habita. Es pues la interacción en el estudio antropológico un elemento fundamental, ya que de lo que se trata no es de develar los secretos de una comunidad, sino de asumir el reto de la autocrítica que fomenta la interculturalidad, y de abrir los espacios de la conciencia y de la disciplina filosófica para asumir posturas donde se funden la palabra con la praxis, pues la palabra es el poder de inspiración y aliento de la praxis. Palabra y praxis son uno mismo en la cotidianidad.

Al comprender un sentido de armonía dentro del cosmos, el hombre se guarda de preservar un lugar que le permita sobrevivir sin destruir el entorno ni a sí mismo - en el espacio físico y significativo de la comunidad- o caer en vicios como el exceso, participando activamente en la permanencia de lo que está. Volvemos pues al sentido originario del estar (Kusch, 1978), al decir que, lo que compete al hombre es comprender su entorno con el fin, no sólo de conocerlo y adaptarse a él, sino también de conservarlo, de aunar esfuerzos para contribuir a la existencia armoniosa del mundo como tal. Satisfacer las necesidades naturales y místicas debe ser un horizonte que vaya acorde con las leyes de la naturaleza, porque de lo contrario habrá caos, desequilibrio y castigo para aquel que las viole. Los personajes más representativos en la tarea de guiar a la comunidad y mediar entre las formas comprensivas del mundo, son los sabedores, los abuelos sabedores que interpretan la naturaleza y al hombre mismo con el fin de dar consejo y promover el equilibrio cósmico.

Dado que en la sabiduría indígena se comprende la vida desde una visión de orden, equilibrio y armonía, entre quienes hacen parte del todo y del todo mismo, la reconciliación sería ese interés y proceso en el que se reordene, se equilibre y se armonice lo que se ha desviado de la condición natural y originaria. Esto es, volver al origen cumpliendo los dictámenes de la ley de origen. Este proceso implica un trabajo personal de carácter espiritual en el que hombre se conoce a sí mismo, se reconoce como parte del todo y actúa en función de la armonía universal. Reconciliarse es conocer, aceptar y vivir la ley de origen, la pertenencia a la Madre Tierra y el amparo de padres espirituales. Volver a la tierra sería parte del horizonte vivencial, conocer los ciclos naturales, sembrar, cultivar y sanar los territorios. La reconciliación comprende desde esta 
óptica transformaciones profundas que se desarrollan a través del reconocimiento del desvío, el perdón a sí mismos y a los demás, la petición de amparo y protección, y la voluntad de enmendar las equivocaciones y las consecuencias que ha acarreado la ceguera espiritual. Desde lo indígena, la reconciliación es un re-encuentro con sí mismo, un despertar de la conciencia y un compromiso con la ley de origen, la Madre Tierra y los padres espirituales.

\subsection{Hilando propuestas, reconociendo conceptos y sentidos para la reconciliación.}

A partir de la teología cristiana y en particular de lo que directamente dicen las Sagradas Escrituras, se entiende la reconciliación como un acto de conversión en el que el hombre logra volver a la comunión con Dios, luego de un proceso de penitencia que incluyen la contrición, la confesión de los pecados, la penitencia y la satisfacción, pasos dados por el pecador para reconciliarse con Dios y volver a un estado previo libre de pecado. Así mismo, esta reconciliación supone el restablecimiento de las relaciones de hermandad entre los hombres, unificados por el poder creador de Dios. La reconciliación se da en lo terrenal con un importante poder espiritual y la fuerza que emana del Espíritu Santo y que se manifiesta para el resarcimiento de los daños causados por la comisión de pecados.

De la breve descripción de la reconciliación en la teología cristiana, se destacan por lo menos dos asuntos que serán relevantes para el desarrollo posterior de la investigación. En primer lugar se rescatan dos principios básicos para la reconciliación: la libertad y la responsabilidad humana. Se parte en este contexto del hecho de que la reconciliación se sustenta en la libertad del sujeto y en su voluntad para la procedencia de aquella. En este sentido, la reconciliación se presenta como un acto libre a la vez que liberador, suprimiendo de entrada la concepción de la justificación de los medios por el fin. La libertad humana para la reconciliación implica una cuota altísima de participación de los sujetos en la definición y ejecución de las políticas que se proyecten para tal fin, aportando en la garantía de la misma libertad manifestada en la expresión de ideales y sentidos de la guerra y su terminación. De otro lado, la responsabilidad como principio humano abre la reflexión sobre la alteridad y la reciprocidad, así como de la reparación, asuntos todos que se abordarán con mayor detenimiento en el capítulo siguiente. 
En segundo lugar, es preciso notar la relación entre el acto de penitencia y los derechos de las víctimas consagrados en la teoría de la justicia transicional. Se entiende que en la línea teológica la postura se inscribe en una concepción espiritual, asumiendo como base la relación entre Dios y el hombre, mientras que el Derecho, y concretamente el derecho positivo en el cual se inscribe la justicia transicional, se fundamenta en la relación entre los hombres. En el primer enfoque, la reconciliación aboga por el retorno a la comunión con Dios en la que la conducta del hombre se debe dirigir bajo la ley divina, mientras que en el segundo enfoque, se trata de la ley positiva redactada por los hombres en un contexto de la sociedad o la comunidad política. Lo primero se da desde la comprensión de una comunidad religiosa, hermana, fraterna de prójimos, y en el segundo caso, se obedece a una comunidad de ciudadanos, esto es, una comunidad civil regida por normas positivas. Guardando entonces las proporciones que vienen al caso, se puede identificar una línea de acercamiento entre los principios y actos de uno y otro enfoque. Así, el acto de confesión de los pecados se identifica con el derecho a la verdad, la satisfacción con el derecho a la reparación, y en general el sacramento de la reconciliación se encauza hacia la justicia (entendiendo que los pecados son causantes de injusticias) y hacia la firme voluntad del hombre de no volver a pecar, asunto que se puede entender como la 'no repetición'. Si bien esto no constituye un objetivo de estudio en sí mismo en el presente trabajo, resulta significativo mencionarlo, con el fin de encontrar hilos de comprensión entre las disciplinas que abordan el concepto de la reconciliación.

Ahora bien, con teólogos como Comblin y R. Schreiter, se avanza en una mirada socio-política de la reconciliación sustentada en la interpretación cristiana de la misma, en la que se expone que se hace necesario tanto un esfuerzo espiritual como uno político para el logro de la reconciliación, puesto que la misma depende de cambios que logren la superación de las formas de dominación que ejercen algunos sujetos sobre otros o algunas instituciones sobre aquellos. Esta premisa da pie para indagar por las causas de los conflictos sociales y armados que abundan en el país, y para establecer el salto que se presenta entre la reconciliación desde la teología y la reconciliación desde la política y el Derecho. En este sentido, la investigación se enfoca en la mirada socio-política de la reconciliación que abre la pregunta por las condiciones materiales e institucionales para la misma, partiendo de las relaciones entre ciudadanos, habitantes de un 
territorio, y distanciándose, sin negarla, de la mirada hermanada que propone la visión cristiana. El concepto de reconciliación que se desarrolla se inscribe entonces en la relación entre sujetos, sin contemplar la comunión con Dios, asumiendo como suelo social el concepto de comunidad política. Sin embargo, por las condiciones religioso-culturales de una medida considerable de colombianos, es menester describir de manera sucinta los principios e implicaciones de la reconciliación desde la mirada de la Iglesia Católica.

Viene al paso la pregunta de en qué momento la reconciliación que ha sido una cuestión casi exclusiva de la religión, se convierte en un problema filosófico. O bien, cómo la reconciliación puede considerarse y abordarse como problema filosófico. La primera respuesta que puede darse, dicta que el problema se filtra a través de las preguntas de la filosofía política, y que acontece en el siglo XX mundial. Como se mencionó en el apartado 1.2 del presente capítulo, tanto la humanidad como la filosofía se vieron en una encrucijada ante los hechos violentos que marcaron la historia del pasado siglo, y se fue testigo de la capacidad humana para, a pesar de los avances "humanistas", desatar hechos e ideas que atentaban precisamente contra la humanidad y la dignidad humanas. Al mismo tiempo, la convulsión en la consolidación de estados "tardíos", los efectos de la colonialidad y la creciente globalización, reconfiguraron el contexto mundial de la filosofía, y las viejas cuestiones no respondían las preguntas políticas del presente global.

En este escenario, se actualizan o bien emergen preguntas por la convivencia global, el pluralismo, y en el caso concreto de las guerras y sus terminaciones, surgen las preguntas por el posconflicto, la construcción de paz, el logro y consolidación de las democracias, las posibilidades del "vivir juntos", y la reconciliación. Estas cuestiones están fuertemente animadas por tres cuestiones centrales, a saber, el Estado de Derecho, la democracia y los Derechos Humanos. Y la cuestión no se limita a la teoría política, ni a la ciencia política, sino que se presenta como necesidad principalmente a la filosofía política, en la medida en que se buscan reflexiones normativas que orienten o bien, justifiquen la reconstrucción social de los múltiples escenarios de la guerra y la posguerra. El problema filosófico se remonta a la pregunta clásica de la comunidad política, desde el sentido normativo de su función y sistema de organización. También se orienta la cuestión desde la pregunta por la democracia, sus principios y definición. 
De otro lado, pero no queriendo establecer una diferencia radical, sino más integrativa, sale al paso el tema de la reconciliación como problema ético, precisamente de ese "vivir juntos" y de las problemáticas que plantea tanto las causas, como la dinámica y los efectos de la guerra. Salen al paso las preguntas por lo justo y lo injusto, por los límites entre lo humano y lo inhumano, y la desesperada intención un tanto frustrante de establecer cuál es, de qué se compone y en qué cosiste la condición humana. La guerra causa perplejo en el sobreviviente, tal vez un poco menos en el espectador, pero es un acontecimiento que provoca la pregunta por el ser en una casi ineludible inclinación por el deber ser. Y en medio de la guerra, pero sobre todo, en la posguerra, cuando hay chance de vivir, la pregunta por lo bueno y lo malo cobra un sentido apremiante en el laberinto del dolor y las percepciones y hechos de injusticias.

Del mismo modo, del sufrimiento de las víctimas, surgen filosofías que aportan reflexiones nacidas de la realidad concreta de la guerra y sus efectos, y que hacen parte de la reflexión que aquí se propone para la reconciliación en Colombia. Es el caso de algunas posturas expuestas por filósofos como Walter Benjamín, Th. Adorno, E. Levinas, Reyes Mate y J. Derrida. Se parte de la necesidad de darle sentido a la filosofía y se asume la postura expuesta por Adorno, de una perspectiva crítica, que dicta la exigencia filosófica de que las reflexiones partan de la realidad concreta y que los problemas se planteen sobre la base de los acontecimientos. Y a la par se construye una crítica a la historia enarbolada por Benjamín, que abre la posibilidad y la necesidad filosófica de la memoria como hecho insurgente frente a la historia, que según él, ha sido un analgésico para el dolor y la narración oficial de los vencedores. Existen entonces hechos, acontecimiento y dolores no narrados, y que por tal, aparecen negados y re-negados. Y frente a la negación del otro, surge la propuesta levinasiana de la alteridad.

E. Lévinas propone una concepción de la alteridad, una teoría de la otredad, que aporta en la comprensión alternativa de la individualidad y convoca un propósito ético primario de las relaciones sociales y la condición humana. La alteridad sienta las bases para una sociedad reconciliada en la medida en que supone la relación intersubjetiva del ser humano que reconoce, es responsable e interpelado con y por el otro. La alteridad es la categoría y la comprensión que permite proponer un escenario de posconflicto en la medida en que establece el principio de vida del otro como constitutivo del sí mismo, con lo cual se puede pensar en la idea de comunidad, o 
bien de un "vivir juntos". La alteridad se presenta como lo contrario a la negación del otro, praxis que soporta la ideología y los hechos de la guerra y las distintas manifestaciones de violencia.

Avanzando, con Reyes Mate se plantea la cuestión de la justicia que se sustenta en dos categorías claves: la memoria y la reconstrucción (que puede leerse también como restitución o reparación). La justicia anamnética planteada por Reyes Mate sostiene una distancia de la justicia penal, en la medida en que marca el acento en el prejuicio objetivo y no en el delito cometido, es decir, que la justicia se sustenta en el dolor o daño causado a la víctima por encima del acto delictivo del victimario. Esta mirada da pie para asumir de manera integral la justicia con la reparación, pues la carga de lo que se puede llamar justo, es la restauración de la víctima y no tanto el castigo otorgado a quien comete el acto perjudicial. Este sentido de la justicia, que además convoca a un proceso social complejo de memoria y re-significación del pasado y del dolor, permite que en la reconciliación las víctimas ocupen un lugar central y fundamental de la reconstrucción del tejido social.

Conviene advertir que, si bien estas categorías y propuestas filosóficas no nacen propiamente de una teoría o una filosofía de la reconciliación, si constituyen una base filosófica para pensar el problema de la reconciliación. Tenemos entonces que las categorías filosóficas desde las cuales se podría abordar el problema de la reconciliación son: la memoria, la verdad, la alteridad, la justicia, la reparación y el perdón.

A continuación se da paso a la presentación de algunas miradas de la reconciliación política, efectuando con anterioridad una breve descripción de la definición de política expuesta por dos pensadores de la disciplina, C. Schmitt y H. Arendt. Esta exposición servirá para avanzar en una definición de política que funciona como suelo conceptual y fundamento filosófico de la perspectiva de reconciliación que aquí se propone. Dicho concepto será expuesto en el capítulo tercero y recoge algunos principios señalados en este apartado, tales como, el consenso, el disenso, la organización social, el pluralismo (re-comprendido a partir del concepto de diversidad), la comunidad política y las relaciones de poder. En términos generales, se propone una transformación en el entendimiento y praxis de la política que supere la definición 
dicotómica schmittiana de amigo/enemigo, asuma las categorías de libertad, diálogo y "lo diverso" de Arendt, pero liberándose de una visión limitada sobre el individuo, para vislumbrar efectos de la pragmática y el sentido de la comunidad y el hecho social del ser humano.

Del mismo modo, se recogen las apuestas por una reconciliación como camino democrático hacia la democracia y la decisión social de la resolución de conflictos a través del encuentro, el diálogo, el ejercicio pleno de los derechos humanos y la reconstrucción social basada en la transformación estructural de las problemáticas sociales causantes de los conflictos armados y la violencia política. En base a lo anterior, se propone como sustento de la reconciliación, la construcción de la paz positiva desde un enfoque de participación ciudadana, que comprenda la paz como un estado de no violencia, a la vez que como un escenario que garantiza el goce de las generaciones de derechos humanos. La paz positiva se constituye en base a la justicia social y predominan principios como la igualdad, en el entendido de que la garantía de los derechos fundamentales depende de la garantía de los derechos sociales, económicos y culturales, por el grado de conexidad que existe entre unos y otros. Esto conduce a pensar en que la justicia social y el sentido distributivo de la justicia están en el centro de la concepción de la paz y la democracia y convoca la necesidad de pensar estas categorías en clave de reconciliación, asuntos que serán desarrollados en el tercer capítulo, cuando se aborden las cuestiones de la paz, el posconflicto y las condiciones objetivas para la reconciliación en Colombia.

De otro lado, existe otra concepción de justicia que resulta relevante e ineludible para abordar el problema de la reconciliación y que se denomina justicia transicional, a partir de la cual se comprende la definición de la reconciliación en el Derecho y que permite la discusión sobre el perdón político y el perdón penal. En la justicia transicional la reconciliación aparece como uno de sus objetivos y se refiere a la reconstrucción del tejido social y las relaciones que se establecen entre las víctimas y los victimarios, casi exclusivamente. Para el presente trabajo, serán abordados sobre todo, dos cuestiones de la justicia transicional, los derechos de las víctimas y el perdón desde la mirada jurídica.

Sin embargo, la presente visión de reconciliación supera la mirada dela reconciliación como un objetivo de la justicia transicional, y sitúa a aquella como un fin en sí mismo, y más pone a esta 
como uno de tantos medios para el logro de la reconciliación, suponiendo que esta no se limita a este tipo de justicia para ser posible. Es preciso señalar que la justicia transicional retoma discusiones importantes en torno a conceptos como la paz, la justicia, el perdón, y plantea problemas entre ellos del tipo de, ¿qué debe predominar para el logro de la reconciliación, el perdón jurídico o la justicia penal?, o bien, ¿qué es más importante la verdad, o el olvido?, en escenarios transicionales, ¿cómo impedir la impunidad y a la vez conceder beneficios a los victimarios para que dejen de delinquir?

El planteamiento que se hace de la justicia transicional obedece a la interpretación no sólo de los preceptos normativos de la misma, sino sobre todo, de la interpretación de las experiencias que en el país ha habido con respecto a los derechos de las víctimas y el diseño y aplicación de las normas, puntualmente en el proceso establecido entre el gobierno del ex presidente Uribe Vélez y los grupos paramilitares de las AUC en la pasada década. Los puntos centrales tienen que ver con la participación de las víctimas y la delimitación de la garantía de los derechos sociales y los derechos de las víctimas.

Finalmente, para completar un esbozo de mapa sobre el concepto de la reconciliación, se ha propuesto una breve pero significativa descripción de algunos principios y comprensiones que ofrece la sabiduría amerindia y que aportan puntualmente en cuatro contextos y significantes en el desarrollo de la investigación. El primero tiene que ver con el hecho histórico del nacimiento violento del continente americano, y la necesidad de asumir el sufrimiento padecido por las comunidades indígenas y la dominación que por siglos se ha ejercido sobre ellas en los distintos niveles del ser. Siguiendo a Reyes Mate, las injusticias del pasado no se claudican por el hecho de ser pasado, sino que el pasado se nos hace presente en la memoria de las víctimas. La opresión sobre los pueblos indígenas no ha cesado y es fundamental asumir un proceso de sanación, liberación y comprensión del ser latinoamericano que en su origen desde la ancestralidad es indígena. Esta reflexión en profundidad y detenimiento sobrepasa el alcance de la presente investigación, en tanto que se refiere a un nivel trascendental, mucho más que político, sin embargo, se ha decidido enunciarla y tenerla de presente como esfuerzo investigativo para próximas labores personales y académicas, entendiendo de todos modos, que el reconocimiento de la memoria indígena y la re-significación de la historia ancestral puede ser 
un propósito nacional con implicaciones y necesidades políticas. Dentro de estas necesidades surge el problema de la colonialidad y la urgencia material, cultural y espiritual de la decolonialidad.

El segundo punto a resaltar es el significado que para las comunidades indígenas tiene la palabra como fuerza creadora. La palabra para los indígenas es un ritual de conocimiento y una vivencia hacedora, es creatividad y poder de creación. En este sentido, sería interesante proponer la relación entre la palabra desde el sentido indígena y la memoria como posibilidad de crear nuevas realidades, desde la rememoración del pasado. Memoria y narrativa aparecen como escenarios discursivos y dialógicos de lo nuevo, en tanto que expresión creada. Esta es apenas una hipótesis que podría arrojar resultados importantes para la reconciliación, a partir de los escenarios de la memoria, la verdad y el diálogo intercultural.

Luego, la cosmovisión indígena abre el sentido de la reciprocidad en el entramado de la comunidad entendida en la máxima del cosmos. La reciprocidad se entiende a partir de la premisa de que todos hacemos parte de un mismo cosmos y que los actos de cada uno repercuten en el todo, desencadenándose de allí un sentido del deber sobre el otro y sobre el todo. La reciprocidad se presenta por lo tanto mínimamente entre dos seres, pero las acciones de estos impactan al conjunto. Se reconocen dos elementos fundantes, por un lado, la visión máxima de relación humana dentro del cosmos en el entendido de la interacción absoluta de los seres, y por otro lado, el deber que deriva en responsabilidad entre dichos seres.

Por último, el saber ancestral pone de manifiesto el pilar del territorio en la definición de lo humano. La relación del hombre con la naturaleza entendida desde lo indígena, sugiere la revisión de lo que hoy definimos como hombre y su lugar en el mundo, y además en términos políticos y culturales, abre la posibilidad de re comprensión de categorías teórico-vivenciales como la tierra y el territorio. El estudio de la vida de los pueblos indígenas ha suscitado una serie de indagaciones y propuestas académicas importantes en torno a la territorialidad en el entendido de la relación existencial, sagrada y simbólica entre el ser humano y la tierra. 


\begin{tabular}{|c|c|c|c|}
\hline Disciplina & Pregunta & Problema & Solución \\
\hline Teología & $\begin{array}{l}\text { ¿Cómo tener una } \\
\text { vida divina? }\end{array}$ & $\begin{array}{l}\text { Mal: Pecado } \\
\text { El hombre se alejó } \\
\text { de Dios por el } \\
\text { pecado }\end{array}$ & $\begin{array}{l}\text { Reconciliarse con Dios y los } \\
\text { hombres a través del sacramento } \\
\text { de la reconciliación, y el perdón } \\
\text { de los pecados }\end{array}$ \\
\hline Filosofía & ¿Cómo vivir juntos? & $\begin{array}{l}\text { Mal: condición } \\
\text { humana, cultural. } \\
\text { La cultura } \\
\text { occidental es } \\
\text { esencialmente } \\
\text { violenta }\end{array}$ & $\begin{array}{l}\text { Ejercer la alteridad, la justicia y } \\
\text { la memoria como fundamento de } \\
\text { un hombre y una sociedad } \\
\text { reconciliados. }\end{array}$ \\
\hline Política & $\begin{array}{l}\text { ¿Cuál es la forma } \\
\text { ideal } \\
\text { organización social? }\end{array}$ & $\begin{array}{l}\text { Mal: violencia } \\
\text { La sociedad tiene } \\
\text { conflictos que } \\
\text { crean } \\
\text { desequilibrios. }\end{array}$ & $\begin{array}{l}\text { Llegar a acuerdos entre las partes } \\
\text { para superar los conflictos. }\end{array}$ \\
\hline Derecho & $\begin{array}{l}\text { ¿Cómo vivir en un } \\
\text { Estado de Derecho? }\end{array}$ & $\begin{array}{l}\text { Mal: Delito } \\
\text { El hombre comete } \\
\text { delitos que violan } \\
\text { la ley }\end{array}$ & $\begin{array}{l}\text { Se debe castigar el mal. En un } \\
\text { proceso de reconciliación, crear } \\
\text { alternativas penales y formas } \\
\text { especiales de justicia. }\end{array}$ \\
\hline $\begin{array}{l}\text { Sabiduría } \\
\text { indígena }\end{array}$ & $\begin{array}{l}\text { ¿Cómo reordenar la } \\
\text { vida? }\end{array}$ & $\begin{array}{l}\text { Mal: Vicio } \\
\text { El hombre desvió } \\
\text { el camino. }\end{array}$ & $\begin{array}{l}\text { Volver al origen. Poner en } \\
\text { práctica la ley de origen. } \\
\text { Fortalecer la espiritualidad del } \\
\text { hombre. }\end{array}$ \\
\hline
\end{tabular}

TABLA 1. El problema de la reconciliación desde las distintas disciplinas y campos de conocimiento. 


\section{CAPÍTULO II \\ LA SOCIEDAD DEL PERDÓN}

Este capítulo se propone explorar y poner en diálogo los distintos conceptos y categorías de análisis que permitirían dar cuenta del fundamento personal y social para la construcción de la reconciliación de miras a un acuerdo de paz sobre el conflicto armado colombiano, suponiendo lo que se podría denominar la sociedad del perdón, como la condición base sobre la que se reestructure el nuevo orden social de posconflicto.

Proponer la sociedad del perdón como condición sine qua non de la reconciliación plantea serios retos no sólo a nivel filosófico, sino por supuesto, a nivel práctico de la realidad social. Varios son los asuntos que entrarían a ocupar un lugar determinante en su concepción y desarrollo, entre los cuales podemos mencionar rápidamente algunos que polemizan la cuestión. Sin embargo, antes de dar paso a dichos asuntos, es necesario por lo menos mencionar la importancia del perdón dentro del proceso de reconciliación a nivel general. El perdón constituye la posibilidad de que la sociedad avance a estadios tolerantes y no violentos, en la medida en que anula la latencia de la venganza, el resentimiento y el odio, provocando actitudes de tolerancia, aceptación, alteridad y permitiendo la puesta en escena de procesos de sanación y cicatrización

individual y colectiva de heridas, dolores y daños morales y psicológicos. El perdón es la condición del cambio en términos de una nueva mirada sobre sí mismo y sobre el Otro, y se posibilita en la medida en que exista una comprensión profunda de la condición humana. En palabras de Arendt (2003),

Sólo mediante esta mutua exoneración de lo que han hecho los hombres siguen siendo agentes libres, sólo por la constante determinación de cambiar de opinión y comenzar otra vez se les confía un poder tan grande como es el de iniciar algo nuevo. (p. 259-260)

Para empezar podemos recordar que la teología y específicamente la concepción de la Iglesia Católica, plantea que el perdón es un don de Dios, es decir, que el perdón al ser una concesión de Dios, depende de su voluntad, por lo que a su vez no es de carácter humano en el sentido de 
propiedad o competencia, ejerciendo un límite a las posibilidades humanas en cuanto al perdón, que por ser una gracia divina supone una relación espiritual cercana y profunda con la deidad, y así mismo la voluntad de dicha deidad para absolver los pecados. La fuente del perdón es Dios, no el hombre. Con la llegada de Jesús y a lo largo del Nuevo Testamento de las Sagradas Escrituras, el perdón adquiere una concepción temporal y ocupa un lugar importante en las relaciones entre los hombres. Aunque también se habla del perdón de los hombres entre sí, de la reconciliación de hombres como hermanos, la naturaleza del perdón sigue siendo divina, no humana.

Contrariamente, a nivel antropológico y ético, el perdón se concibe como una virtud humana; el perdón es la capacidad espiritual o racional (según la escuela y el carácter humano desde donde hablemos) del ser humano para dar al Otro, o darse a sí mismo la concesión de perdón sobre una falta, error o calamidad cometida que afecta a la persona, ya sea en su condición física o moral, por la cual esta se siente ofendida. En este sentido, el perdón es un acto voluntario restringido a la esfera individual o al espacio interno del hombre, y por lo tanto, no es exigible, no se puede decretar, sino que su naturaleza corresponde totalmente a la voluntad individual, ya sea de quien da perdón o de quien decide recibir o aceptar el perdón que Otro le ofrece, dejando de sentir resentimiento o ansias de venganza contra quien causó la ofensa.

Con respecto al ámbito jurídico, la idea de perdón se ha entendido a través de dos figuras principalmente: la amnistía y el indulto, que en sí son la extinción de responsabilidad penal. Por un lado, el indulto individual, es el pronunciamiento legal o el acto administrativo con carácter de ley, que expide la autoridad competente, en el que la persona sigue siendo culpable, pero se le perdona la pena o castigo a pagar. Esto es, que se trata de un perdón sobre la pena, más no sobre el delito. Es un caso especial en el que no se impone la sanción sobre la pena, pero el delito existe. De otro lado, la amnistía es principalmente de carácter colectiva y recae sobre el delito, por lo que el grupo de personas deja de ser culpable, y por lo tanto no debe cumplir la condena que se supone prescrita de acuerdo al delito. La amnistía es el perdón del delito y es un requisito que se decrete por vía de una ley de amnistía. 
[L]a amnistía es el recurso que un Estado puede poner en práctica, por el cual se impide que el responsable de un delito sea juzgado penalmente. Se habla de un olvido, más que de un perdón, del crimen cometido. La amnistía se diferencia del indulto, pues en este no se olvida el crimen cometido, sino que se exime al responsable condenado de la aplicación del castigo, sin que esto implique que se borre la condena en la que se basa. Estos dos instrumentos han sido ampliamente utilizados en procesos de justicia transicional, especialmente con el fin de convencer a los actores armados o a los miembros del régimen autoritario de participar en un proceso de paz o tomar parte en la transición al nuevo régimen. (Observatorio de construcción de Paz, 2013, p.14-15)

En escenarios de transición conflicto/posconflicto, negociaciones y acuerdos de paz o finalización de estado de guerra, el perdón jurídico implica la reconsideración del Derecho y de las normas constitucionales y penales que configuran el Estado de Derecho, de modo que principios punitivos y judiciales sufren cambios severos o ausencias problemáticas; se trata pues de la revisión y adecuación del marco jurídico del Estado para la asimilación del escenario de posconflicto. En este contexto se complejizan las dicotomías por sí mismas problemáticas de: justicia/impunidad, paz/justicia, perdón y olvido, víctima/victimario, que constituyen el fondo de discusión y la naturaleza misma de la justicia transicional.

Ahora bien, ¿se podría hablar de algo denominado el perdón político? En principio es preciso anotar que, el "posconflicto" se convierte en un verdadero campo de batalla, tanto a nivel armado (reestructuración de órdenes militares), como a nivel político. Si el conflicto armado en sí mismo es violento, el posconflicto no deja de serlo por el mero acuerdo de las partes, pues en la transición se van dando, en medio de múltiples y agudas tensiones, las pautas y reglas del ordenamiento social, se refigura la comunidad política y sus principios. El riesgo político en torno al perdón es que, si se otorga demasiado (de parte del Estado a los victimarios), sectores sociales en particular las víctimas no quedarán satisfechos y serán posibles semillas del descontento y futuro conflicto; contrariamente, si el perdón es muy estrecho, algunas de las partes, por ejemplo, los actores armados al margen de la ley, no acepten el acuerdo por verse sometidos a términos que no son suficientes para sí mismos. Se debe entender por demás que esa medida del perdón que de por sí no es medible, en tanto que perdón, consiste en la percepción del nivel de perdón de los actores. El perdón político puede consistir tanto en las peticiones 
públicas de perdón (de distintos actores e instituciones), como en la compensación y clemencia hacia ciertos sectores o actores sociales.

Teniendo en cuenta estos y otros asuntos que se irán esbozando, habrá que plantear cuáles son los límites y las posibilidades de la sociedad del perdón como configuración de la estructura personal y social de la comunidad política que se reconfigura en un escenario de posconflicto a través del proceso de la reconciliación. Para lo cual, como se mencionó anteriormente, se describirán y analizarán categorías que arrojen pistas y permitan profundizar el marco conceptual para dar cuenta del objetivo de la actual investigación, dándole tratamiento a las polémicas señaladas y avanzando en propuestas de estudio filosófico. Concretamente se abordarán: la memoria y la no memoria, el principio de reciprocidad, la alteridad, la justicia y la reparación.

\subsection{Miradas y prácticas de memoria y no memoria}

Para iniciar este apartado se hace mención de una serie de interrogantes que surgen al acercarse al tema de la memoria, para ir dándoles tratamiento y dejar abierto el debate en torno a los retos y posibilidades de la memoria como apuesta ética de la filosofía y como derecho del ser humano, sobretodo en contextos de conflicto armado/posconflicto, es decir, en escenarios transicionales. Así pues, preguntar, siempre en clave de la pregunta de investigación ${ }^{3}$ : ¿qué es la memoria?, ¿qué tipos de memoria existen?, ¿cómo debe ser la memoria para un proceso de reconciliación?, ¿cómo evitar que los procesos de construcción de memoria colectiva, nacional o histórica desemboquen en nuevos ciclos de violencia, o que aviven el fuego del rencor?, ¿cuál es la importancia de la construcción de memoria en un proceso de reconciliación?, en términos jurídico-políticos ¿es la memoria un derecho del ciudadano?, si es así ¿de quién es el derecho a la memoria?, ¿podríamos hablar del derecho a la no memoria?, ¿cuáles son los retos que plantea la construcción de memoria en la reconstrucción del orden social?, ¿quién tiene la legitimidad para "hacer memoria"?. Son estas cuestiones que problematizan a la vez que permiten abrir la

\footnotetext{
${ }^{3}$ Es importante aclarar que el tema de la memoria se inscribe en el contexto de los procesos de transición social, y desde las prácticas que ellos involucran. No nos referimos a la memoria en un sentido ajeno al hilo conductor de la investigación.
} 
discusión en torno a la memoria como proceso individual y colectivo en el marco amplio de la reconciliación.

En algunos procesos se ha supuesto que el olvido es una condición para avanzar en los propósitos de reconciliación, ya que de recordar, los odios y resentimientos no se superarían; sin embargo, para el presente, esta situación es contradictoria, en la medida en que la reconciliación supone precisamente un ejercicio de recuerdo, o de memoria si se quiere, porque la justicia, la defensa de los derechos de las víctimas, el perdón y el conocimiento de los hechos y razones de la violencia, constituyen un propósito fundamental para construir un ambiente propicio para restablecer confianzas y lazos de solidaridad y comunidad entre los distintos sujetos e instituciones involucrados de manera amplia.

De igual manera, la construcción de la verdad en los procesos transicionales -que son de alguna manera el contexto en los cuales se propone la reconciliación- debe comprender de manera comprometida la voz de las víctimas, su mirada, sus experiencias, y lo debe hacer de un modo respetuoso y creativo, en la medida en que su voz puede no hablar el lenguaje común a las exigencias judiciales de los trámites de las comisiones de verdad y testimoniales. El dolor y el sufrimiento se expresan de distintas formas, que incluyen los silencios, las miradas profundas o el lenguaje sensible de la emoción, cuestiones que pocas veces son tenidas en cuenta, pero que constituyen un valor de suprema importancia en el proceso de dignificación de la víctima, que es entre cosas, un proceso autónomo a la vez que social.

En el espacio y en el tiempo hay recuerdos que escapan a la posibilidad de observación; quien sufre una desgracia conserva en sí mismo la experiencia de la realidad que para otro no tiene existencia, que no hace parte de su comprensión del mundo. De ahí que la comprensión, al no captar eso otro que para el Otro es, sea parcial en la dimensión de la realidad. Con esta afirmación se pone en debate la trascendencia epistemológica de la memoria y de la voz de los distintos actores sociales que participan de una $\mathrm{u}$ otra forma en el conflicto armado. Principalmente se reposa la mirada sobre el dolor de la víctima como condición de verdad, en la medida en que su conocimiento, de los hechos, del dolor y sufrimientos enraizados en su memoria (de la mente, del cuerpo) contienen información que constituye una parte de la realidad 
social, sin la cual, la verdad o la historia quedarán incompletas, serán parciales y cumplirán un papel encubridor del mal.

Es pues no sólo una condición de verdad, sino un principio ético, permitir que sea la voz de la víctima la que exprese, esa voz que tiene mucho que decirnos (ya sea desde el silencio o la pronunciación/enunciación), que posee una experiencia y un fragmento de realidad que compone la verdad, pero que no se reconoce como tal. Sin la voz de la víctima, la realidad estará ausente de un referente central de veracidad. Esta actitud invita a repensar el alcance actual de la definición de la verdad, y asumir nuevos espacios para su construcción, como lo propone Theodor Adorno, desde el dolor y sufrimiento del oprimido, del que conoce más que cualquier otro las vivencias de violencia desde una mirada propia de sensibilidad.

Se observa en este punto una relación constitutiva entre verdad y memoria. La memoria, el ejercicio de la memoria, el hablar, el pronunciamiento del dolor, la enunciación de los hechos y el decir de la experiencia, son parte fundamental de la construcción de verdad social, de verdad histórica. Pero su alcance no concluye allí, pues la misma verdad nos conduce a hacer algo con esa verdad. La verdad no está allí para ser sabida, para verla y seguir de largo. Si existe la verdad es para hacer algo con ella, más que saberla. La verdad contiene en sí misma el principio del orden, de lo que es como es, en relación a lo debe ser. Por lo tanto, la memoria nos conduce a la verdad, y ésta nos va adentrando en el problema de lo que debe ser, y en términos puntuales a la pregunta por la justicia. Cómo nos conduce la verdad a la justicia, y en un nivel personal, cómo lo hace la memoria.

La memoria se remonta a hechos ocurridos en el pasado, en un tiempo que no es el de la actualidad de la memoria, y por lo tanto hechos ubicados fuera del alcance del aquí y el ahora actuales. Sin embargo, la justicia no obedece a ese mismo tipo de temporalidad, puesto que, si las injusticias pertenecen al pasado, la justicia, el hacer justicia es un acto siempre actual. Habrá que poner el acento en que "hacer memoria" no se trata de un acto de recuerdo sin más (remitirse a hechos o experiencias del pasado), "hacer memoria" implica "hacer conciencia" de que el pasado está abierto y que está ahí esperando ser redimido, pues las injusticias no cesan ni se clausuran con el simple 'pasar del tiempo amontonado'. Entonces, el hecho de que la injusticia haya sido 
cometida en el pasado, no clausura la injusticia. Así su tiempo sea el pasado, en la medida de la comisión de la misma, es actual en la medida de su irreparabilidad (Reyes Mate).

El enfoque de la memoria en las políticas gubernamentales que se expiden en el marco de la aplicación de medidas administrativas en un proceso de justicia transicional ha institucionalizado espacios donde se construye el intercambio del lenguaje de nuevos sujetos en la historia del conflicto armado (antes excluidos del sistema social). Los sobrevivientes pueden entonces hacer uso de su voz y tomar la palabra, pueden hacer uso público de su palabra. En este contexto, se trae a colación el estudio de Michel Foucault sobre el problema del decir veraz desarrollado a partir del estudio del vocablo griego parrhesía. Foucault (2009) expone que la parrhesía es

La libertad de tomar la palabra y, en la palabra, ejercer el hablar franco. Para que haya democracia, es preciso que haya parrhesía, [así como] la parresia es uno de los rasgos característicos de la democracia. (p.16)

A lo largo de la primera parte del texto, Foucault reconstruye el significado de la palabra parrhesía que genéricamente es "decir veraz" o el "hablar franco". Pero ese decir veraz, esa verdad es cualquier verdad, es decir, es "cualquier verdad" pero implica una situación de riesgo que hace que no sea como decir "cualquier verdad". Dice Foucault que la parrhesía es un decir veraz, un hablar franco que implica un riesgo para el locutor, quien puede incluso hasta perder su vida. El decir veraz de la parrhesía es el hablar franco sobre una situación de injusticia, sobre algo que hace el soberano, lo que el rey hace y que no debe hacer o que oculta la verdad, la parrhesía irrumpe la impunidad y comunica la verdad, denuncia la injusticia. Es esta una de las formas posibles del decir veraz: es la voz de la persona que dice la verdad sobre una injusticia que se cometió, hace justicia al hablar franco sobre la situación de injusticia.

Esta figura de la parrhesía, aparece en Foucault ligada directamente con el poder político, situando el contexto de las tragedias de Eurípides -fuente de las primeras reflexiones del Foucault-. Se trata de la democracia en Atenas, así como el manejo de asuntos políticos en otras ciudades y temporalidades de la historia griega. Analizando un poco el sentido político y las implicaciones personales de la parrhesía como experiencia del decir veraz, en relación más que 
todo con la justicia, podríamos decir que la víctima tiene el poder de la parrhesía y que sería entonces la legítima constructora de memoria, en la medida en que tiene la verdad y esa verdad se funda en una injusticia sufrida. El decir veraz en este sentido, es un derecho.

Otra de las figuras del decir veraz tiene que ver con la confesión, hablar la verdad para "alivianar el alma". En este sentido, las estrechas relaciones entre algunos actores de instituciones públicas del Estado y las dinámicas y acontecimientos del conflicto armado, en el sentido de la práctica política característica del Estado de Excepción, motivan el pensamiento de que la confesión por parte de funcionarios y políticos tanto de las ramas administrativas como del poder público gubernamental, tienen en sí, lo que se podría constituir como la memoria no oficial de los oficiales del Estado. Habría que reconstruir la trama política dentro del contexto amplio del conflicto armado colombiano, las prácticas de funcionarios clave en algunas instituciones dirigidas a implantar una política de guerra interna.

El manejo de lo público, en medio del conflicto armado, es decir, asumiendo las cuestiones gubernamentales en un estado de guerra interna, supone la creación de ese mundo por fuera de la ley que se legaliza - paradójicamente- en la figura del Estado de excepción, más particularmente en Colombia el Estado de Sitio. Entonces ese mundo tiene a su favor el principio del secreto del príncipe, lo contrario al principio de publicidad en el sistema democrático. No todo lo que se produce al interior del gobierno, como decisiones de Gobierno, o más bien, del gobernante (especialmente del presidente como mando mayor) se revela o hace parte de la rendición de cuentas a los ciudadanos, sino que hace parte de la política oculta, no publicada ni publicitada del gobierno. Se trata del manejo privado del poder público, acto que en sí mismo, según el contexto del conflicto armado y la declaración del Estado de Sitio, no constituye necesariamente un acto ilegal.

Y es en este escenario en el que la pregunta por la memoria, por el qué debe decir la memoria y quien debe "hacer memoria", se hace notar que el Estado de Excepción como sistema de gobierno, contiene una información que la historia de por sí sola, como práctica investigativa no puede conocer, ya que ignora no sólo las fuentes posibles de información, sino por el hecho de que estas pueden no existir más que en una confesión. 
Por otro lado, la memoria, como construcción social e intelectual, aparece como un elemento propositivo que surge de la crítica a la filosofía de la historia. En este sentido, se pone de presente la crítica a la filosofía de la historia que construye los inicios de la teoría crítica de la Escuela de Frankfurt en cabeza de Walter Benjamín y Theodor Adorno, entre otros, y que consiste en argumentar la forma como la historia ha sido un instrumento de conocimiento al servicio de los vencedores de la historia. Cuando se refieren a vencedores, los autores anotan que se trata de que aquellos sean vencedores porque han triunfado más que todo sobre otros en forma opresiva. Los vencedores son los victimarios. Entonces los autores afirman que la historia es parcial, y ejerce un efecto de silenciamiento. Así como la violencia silencia al eliminar la voz del Otro que elimina, que asesina, la historiografía ha eliminado esa voz, al no tener en cuenta su experiencia, su sentido, por lo menos como signo y realidad de ausencia.

De lo que resulta (no en sentido causal, sino propositivo) que la memoria, como ejercicio consciente de rememoración del pasado en clave de momentos trágicos - que marcaron la vida de la persona, de la comunidad-, sea la respuesta a la parcialidad del ejercicio historiográfico. Nadie conoce más la verdad que quien la vive. Nadie puede registrar la experiencia de forma más original que quien vive la experiencia. La propuesta de la Escuela de Frankfurt frente a la memoria se puede asumir como una fenomenología del conflicto armado y sus múltiples escenarios tanto como sentidos posibles. Ahora la pregunta es quién hace el ejercicio fenomenológico. Puede ser tanto la persona que sufre, la víctima que siente el dolor y da actualidad al pasado a través de la emoción, como también puede ser el Otro. Ese que Otro que es interpelado (en términos de Lévinas).

En un sentido amplio, se hace posible pensar en una especie de fenomenología social del conflicto armado, de la situación social, cultural, espiritual y política que tiene su origen en un estado remoto. La reconciliación implica que la sociedad -en el sentido amplio y personalizado del término- haga una fenomenología de sí misma. Asumir una propuesta de posconflicto necesita pasar por un proceso del decir veraz de la comunidad política, -lo cual así mismo supone un componente esencial de la concepción de reconciliación que acá se construye: el reconocimiento del Otro como Otro en el sentido de alteridad desde su sí mismo que se 
mencionó en el primer capítulo y que será abordado con más detalle adelante- que se asume como "objeto de investigación”, se propone conocerse a sí misma, para lo que deberá definir quiénes hacen parte de dicha comunidad política. Quiénes están fuera y quiénes están dentro como ciudadanos que pueden hacer uso público de la palabra, que en el sentido filosófico griego, es la razón.

Se ha dicho que la memoria es un acto de conciencia individual o colectivo, en el que se rememoran experiencias pasadas (que no están sólo instaladas en el pasado como hecho violento, sino también en la utopía, en el silencio, en el anhelo) y que tienen un sentido tanto para quien hace memoria como para quien escucha o conoce el relato del testimonio. También la memoria constituye un factor central en la re significación de la historia y la construcción de la verdad. En interpretación de la propuesta de Adorno, la memoria como praxis y como ideal, comporta tres dimensiones en principio, a saber, lo ontológico que expresa que: la realidad no se reduce a los hechos pues está compuesta así mismo de los silencios, ausencias, de lo invisible y lo oculto, donde el acontecimiento es la excedencia de sentido; lo epistemológico, que contiene la experiencia como fuente y forma de conocimiento en una relación vivencial con el pasado que es significativo, y donde el sufrimiento es un criterio de verdad; y lo moral que expresa el imperativo categórico en una relación entre la memoria y la compasión, definida desde la sensibilidad del concebir truncada la felicidad pasada. Lo que legitima el "hacer memoria" es el uso veraz de la voz pública, así como la experiencia del dolor de quien sufre una injusticia y la hace pública, la pone a disposición del público, expresando sufrimiento e imágenes que constituyen el símbolo de la ausencia, del cambio, del silencio, de lo que será ahora la historia común.

Esquemáticamente podemos señalar los tipos de memoria -como propuesta y como ejercicio de la palabra- que se han abordado en la literatura y la praxis política referente a los procesos transicionales y los derechos de las víctimas. Entre ellos se mencionarán brevemente las categorías de la memoria histórica, la memoria colectiva y la memoria de las víctimas.

[E]n tanto categoría social, política y cultural diferenciada de la historia, la memoria es una manera de representación y recuperación del pasado que, si bien es una acción de cada individuo, es 
afectada por las relaciones sociales en las que este se encuentra. La memoria colectiva, como producto de la interacción de las memorias individuales, permite consolidar múltiples relatos colectivos de sucesos que afectaron a toda una comunidad y que frecuentemente desafían la historia oficial, o aquella historia escrita desde la perspectiva de los vencedores. Dentro de la justicia transicional, se ha vuelto indispensable ver la memoria como una herramienta útil para el esclarecimiento de la verdad de las relaciones entre victimarios y víctimas en periodos de violencia; así mismo, la recuperación de la memoria se concibe como un medio para extraer lecciones del pasado a fin de que las atrocidades no se repitan y se puedan restablecer y consolidar lazos sociales. (Observatorio de construcción de Paz, 2013, p.14)

Para el Grupo de Memoria Histórica (2013) del Centro Nacional de Memoria Histórica de Colombia, la memoria histórica es un esfuerzo de esclarecimiento de la historia, y de los relatos/testimonios que recogen para reconstruir parte del drama sufrido en el conflicto armado, de parte de quienes reconocen como víctimas, como sobrevivientes; en el grupo se identifican tres ejes que estructuran el discurso, del decir de las víctimas, a saber:

1) un eje narrativo que registra el horizonte del dolor y de la crueldad humana desde el que los testigos y sobrevivientes recuerdan lo que pasó; 2) un eje interpretativo que ubica a la complicidad y el estigma como memorias emblemáticas desde las que las víctimas explican los orígenes y las causas del conflicto armado en su territorio, o sea, el por qué pasó lo que pasó; y c) un eje de sentido que registra las respuestas y recursos de las personas frente a la violencia armada con sus numerosos actos de protección, solidaridad, rescate, desobediencia y resistencia directa e indirecta. (p.329)

La memoria histórica no es necesariamente memoria colectiva. En este sentido vale la pena establecer la diferencia. Entre otros escenarios posibles (convivencia pacífica, construcción de ciudadanía, etc.), la memoria histórica se refiere al repertorio de relatos, memorias, testimonios y confesiones en torno a los hechos de violencia, el origen del conflicto y sus dinámicas, las experiencias y sentidos que dan algunas voces respecto a lo vivido, en el marco amplio del propósito del esclarecimiento histórico de la verdad. Mientras que la memoria colectiva se refiere a eso mismo, pero en términos de comunidad, de colectivo, de grupo, es decir, la memoria compartida por los miembros de un grupo social específico, o bien, en caso de que se logre, de la 
memoria compartida como nación. La memoria colectiva es integral y compartida, la memoria histórica es integrativa, incluyente, pero no necesariamente compartida en el sentido y la experiencia de los hechos narrados. La memoria histórica busca esclarecer la verdad, reconstruir la historia, mientras que la memoria colectiva, por más que aporte en dicho propósito, cumple más que todo, una función de reconstrucción de la dignidad y la identidad colectivas.

Ahora bien, la cuestión que constituye el núcleo de la pregunta por la memoria en un proceso de reconciliación, y que se considera asimismo un reto filosófico central de la presente investigación es la relación entre memoria y no repetición. Y en este sentido, cobra relevancia la propuesta de la memoria de las víctimas, en tanto memoria del sufrimiento, del dolor que dice ¡no más!, o como lo denomina el informe general del Centro Nacional de Memoria Histórica (2013) ¡Basta ya! Se hace presente asimismo el imperativo categórico de la propuesta ética de Theodor Adorno: recordar para no repetir. De este modo la memoria no sólo esclarecerá la historia, y será parte esencial de la verdad, sino que conlleva también una proyección clara del nuevo orden social y político: que los actos de violencia no se repitan, que las condiciones que permitieron y promovieron dichos actos (condiciones incluso filosóficas) no sean admisibles nuevamente.

Han quedado apenas planteadas las cuestiones que respecto a la memoria habría que tener claras en un proceso de reconciliación. Pero bien, surge una cuestión respecto de la cual es menester por lo menos hacer una mención y poner a consideración para el debate de la memoria, y es, precisamente su contrario, el tema de la "no memoria". A qué se refiere la "no memoria". Es la forma de resistencia al dolor y la apertura de futuro que asumen algunas personas frente a los hechos y los sentidos del sufrimiento, del pasado, de la violencia, de lo que pasó que no quieren recordar más, como condición de futuro posible. Con esto queda claro que la memoria, así sea un valor absoluto en sí mismo, no puede ser totalizante como forma individual y social de representación del pasado, de construcción de futuro. Es preciso que así como deberán existir esfuerzos de memoria como re significación histórica y verídica, también debe procurarse el respeto a la decisión de "no hacer memoria" como exigencia de parte de quien prefiere dar vuelta a la página sin rememorar, pues puede ser que el dolor sea tan profundo y tan paralizador, que la opción única de futuro sea el "olvido". 
Debe quedar claro que la "no memoria" es una condición individual, y sobre todo una decisión de quien padece el dolor y la negación del recuerdo, más no debe entenderse la "no memoria" como política de Estado, o política de gobierno, ya que la reconciliación supone el conocimiento de los errores, de las injusticias, de las violaciones, de las trasgresiones, por lo que en el caso de un nivel colectivo, social, o nacional si se quiere, el ejercicio de la memoria es el fundamento de la verdad que será a su vez fundamento de la justicia y la reparación.

Se ha concluido, de forma un poco precipitada, pero que será retomada en el capítulo siguiente que, la finalidad y el ejercicio de la memoria, de "hacer memoria" en un escenario de posconflicto eventualmente, o en todo caso, en un proceso de reconciliación, es dar sentido y existencia a la no repetición de los hechos violentos. Y esta no repetición se da por lo menos en dos momentos: en lo que podríamos llamar genéricamente "causas del conflicto armado" y lo que implica las dinámicas propias de la guerra, o sea, el desarrollo de la contienda bélica como tal. Entonces no repetición supone la transformación de las instituciones públicas y morales de la sociedad, así como la negación de los actos de conflicto armado que violentan la integridad física y moral de los ciudadanos. Se considera que si se orienta el ejercicio de la memoria en esta dirección, se podría evitar que la rememoración y la re significación de la historia sean una nueva causa de conflicto armado, que avive los rencores o geste renovados sentimientos que provoquen actos de violencia del tipo a que nos referimos.

\subsection{El principio de la reciprocidad}

Para avanzar en la reflexión de la reconciliación como proceso social y como construcción filosófica, es preciso señalar en qué términos se enfoca el principio de la reciprocidad, como fundamento de una nueva relación social basada en la cosmovisión de lo recíproco como esencia del orden social y universal. En este sentido, y teniendo en cuenta la importancia que comporta la reciprocidad para pensar la reconciliación, se abordará desde tres preguntas principales, en primera instancia, ¿qué es eso de la reciprocidad?, ¿cómo se debe asumir la responsabilidad del conflicto armado a partir del principio de reciprocidad?, y por último, ¿qué aporta la cosmovisión 
de la reciprocidad para fundar un nuevo orden social reconciliado? Estas preguntas buscan abrir el telón de discusión en torno a una categoría muy trabajada por los investigadores de las culturas precolombinas americanas, y también por el Derecho, que pueden brindar elementos de análisis para significar formas de relación social e incluso formas del estar individual, a partir de comprensiones elevadas y complejas de la naturaleza y la sociedad, y que implican repensar asuntos como el orden, la paz, la justicia, lo proporcional, la vida y el estar.

De manera general, la reciprocidad puede ser entendida en dos vías. La primera dirá que la reciprocidad es un intercambio entre dos personas o cosas. La segunda alude a señalar la correspondencia entre dos personas o cosas. Intercambio y correspondencia son los conceptos que significan la reciprocidad. Cuando se alude al intercambio, así como a la correspondencia se presupone una medida de igualdad. El intercambio es la transferencia donde se da y se recibe de manera proporcional, y la correspondencia es la disposición a hacer parte comunicativa e interactiva en un proceso o situación determinada. La correspondencia supone una conexión, una relación de dependencia mutua. Tenemos pues dos principios iniciales de la reciprocidad, por un lado, implica la participación de más de un sujeto o ser, y además, supone una medida de igualdad en términos de proporcionalidad. Habría que asumir un tercer principio que se refiere a la pertenencia a algo, esto es, comprender que las relaciones se dan en un medio, se dan en situación. De ahí que se asuma que las actitudes, las prácticas o lo que acontece, acontece precisamente en un espacio y ese espacio se ve afectado por la participación de los sujetos o de los seres.

Visto en un sentido orgánico, la reciprocidad es la condición de relación de los que participan o están en un espacio tal, y que conduce a la consideración de otras categorías aportadas sobre todo por la sabiduría indígena, tales como, armonía, relacionalidad y complementariedad. Pero no todas las relaciones se presentan bajo estos principios, ni reportan síntomas de las categorías recién mencionadas. Por el contrario, es supuesto aquí, que las relaciones asimétricas y las desigualdades en distintos niveles, así como el desequilibrio en las formas de vida respecto de principios de vida, son la causa a la vez que la esencia misma del conflicto armado. Esto nos lleva a concluir parcialmente que la reciprocidad no es una condición sine qua non de las relaciones, sino que es una forma de relación, esto es, corresponde más a una decisión, a un acto 
de voluntad, que a una ley o situación obligada, dada de por sí. La reciprocidad supone un conocimiento, una decisión y en determinados momentos un acuerdo.

¿Por qué resulta entonces importante considerar la reciprocidad, y lo que comporta, promoverla apelando a la voluntad? Los seres estamos en un mismo orden social y cósmico, atravesado por diversas formas de relación y de interacción, pero que de una u otra forma, consciente o sin tener consciencia de ello, somos afectados a la vez que afectamos dichos órdenes. Asistiendo a la concepción clásica y al principio universalizable de que el todo está compuesto por sus partes y las partes componen el todo, se tiene que si el todo está compuesto por las partes, se ve afectado por principio por lo que suceda en las partes o por lo que las partes propicien o hagan que suceda. Del mismo modo, en sentido inverso, las partes se verán afectadas, tocadas, por lo que el todo ejerza como todo en la comprensión de lo que suceda a su vez con las partes. Cada parte tiene una responsabilidad sobre el todo, tiene participación por lo que produce efectos. Entonces, será preciso asumir una postura crítica de determinación de las voluntades, asumiendo una consciencia de incidencia y de participación en un todo que nos corresponde asumir como sujetos, como seres-partes.

Ahora bien, para asumir la reciprocidad a partir de los principios planteados anteriormente con miras a considerarla dentro de un proceso de reconciliación, se ponderarán algunas situaciones en las que habría que poner acento especial a la hora de reflexionar y proponer en la construcción de nuevas formas de relación social. Antes de ello, será preciso advertir que la antropología social identifica distintos tipos de reciprocidad y que, por lo tanto, se le puede contemplar en varios escenarios de la vida. Uno de ellos, el más común en la tradición Occidental, tiene que ver con la teoría y práctica económica, en el que se aplica la condición de intercambio de bienes entre dos personas en términos proporcionales de igualdad. Otro lugar sería el Derecho que considera el principio de correspondencia en distintos escenarios normativos. En general, la antropología social comprende miradas de las relaciones sociales.

Las anteriores formas de abarcar el tema de la reciprocidad se agotan en los vínculos entre seres humanos. Y lo que se pretende significar en el presente análisis tiene que ver con la siguiente figuración. En gran medida, el conflicto armado colombiano ha generado a la vez que se genera 
por una crisis del espíritu, un agotamiento o vaciamiento espiritual, que encuentra su origen en la separación radical y a veces violenta que pretendió el 'hombre' respecto de la naturaleza. La razón Occidental que llegó al continente con los conquistadores y el ejercicio del poder de la Corona Española, trasladó un pensamiento hostil y temeroso, que tuvo que conquistar lo natural para edificar lo humano. Lo humano de la modernidad que se empieza a configurar con la invasión del Aby Ayala, se caracteriza por un giro radical de la posición del hombre en el mundo, respecto de Dios y respecto de la naturaleza.

El hombre moderno es 'el hombre' en su sentido más totalizador y nominador, ocupando un lugar ontológico central y determinador del mundo. Lo humano se define por oposición, por diferenciación y por una separación esencial del resto de seres, de la naturaleza que tradicionalmente en Occidente es asumida como objeto, ya sea objeto de uso, objeto de conocimiento, objeto de conquista. La naturaleza es conocida para dominarla, para ponerla al servicio del hombre, quien se hace a una posición de sujeto máximo del orden. Pero este hombre no es cualquier hombre, esto es, el sentido de humanidad debe cumplir una serie de condiciones de tipo formal, material, religioso y ético, que es definido por este prohombre moderno.

El hombre moderno determina tanto a la naturaleza, como a los otros hombres, a esas culturas distintas de la suya que para acceder al status de hombre debe cumplir con parámetros culturales propios de la vanguardia humanista del que denomina. En este sentido, la construcción occidental del principio de la reciprocidad sólo cobra sentido en la medida en que se refiera a las relaciones humanas entre humanos, valga la redundancia.

Se considera que este paradigma de lo humano debe ser replanteado y que se deben rescatar las posiciones que ubican lo humano en un sentido más integral y universal de las conexiones, de los efectos y de las dinámicas entre lo humano y lo no humano, en un sentido ontológico orgánico, para tener una comprensión amplia y responsable del principio de reciprocidad. Poder reconstruir una mirada amplia del sentido de reciprocidad, a la vez que se pueda aplicar dicho sentido a momentos más concretos, es el propósito de este apartado, por lo cual, se ubicarán dos visiones: una que tiene que ver con actitudes políticas y la otra que se refiere a un sentido más trascendental de relación, basada en cosmovisiones indígenas de América Latina. 
Si se aplica la estructura de la reciprocidad a la pregunta por la responsabilidad de los actores armados en el conflicto interno de Colombia, obtenemos la fórmula de que cada uno debe asumir parte en la responsabilidad que por sus actos le corresponde asumir. Se trata de dar y recibir lo que se debe en relación con lo que se ha hecho en el campo político y en el campo de batalla. Cada actor debe ocupar el lugar que le corresponde en el proceso de la reconciliación, ahora bien, ¿cuál es ese lugar? El punto de partida es el reconocimiento del lugar que supone ser un actor en conflicto, propiamente hablando, un actor armado. Asumirse como 'ser' en conflicto, supone dos cuestiones: por un lado, darle la cara al conflicto en términos de realidad, esto es, asumir la realidad del conflicto armado y de ahí, estar dispuesto a comprenderlo. Y por otro lado, situarse como actor armado es reconocerse como tal, identificando las posiciones y prácticas que hicieron parte constitutiva del conflicto, siempre en relación a Otro. Pensarse como actor en conflicto, implica asumir una posición responsable de la historia, de la influencia sobre la construcción o destrucción del tejido social.

Para entrar a la cuestión de ¿cómo aporta el principio de reciprocidad a la construcción de reconciliación?, es preciso exponer la visión de algunas comunidades que comprenden el concepto de una manera amplia, profunda y trascendental. En este apartado se estudian dos aspectos del principio: la organización social y la organización universal. En un sentido de complementariedad dentro de la concepción de la comunidad, el hombre como ser social y el lugar del hombre en el mundo.

En este sentido vale la pena traer a colación el rescate de la sabiduría quechua recogido en los estudios del filósofo suizo Josef Estermann, quien reconoce cinco principios del pensamiento andino: la relacionalidad, la correspondencia, la complementariedad, la reciprocidad y la ciclicidad. Estos principios conforman la base intelectiva y sustancial de una ética andina, que a su vez se fundamente en el concepto central y abarcador pacha, que según Estermann, filosóficamente significa "universo ordenado en categorías espaciotemporales". El vocablo puede ser significante también del "mundo de la vida", del "ser", pacha se refiere a lo que es, lo que está dado como realidad. Y el ser humano se encuentra en la pacha como ser, como miembro, como parte de la misma. La racionalidad andina comprende al hombre como parte 
de... y no como dador de sentido de... el hombre hace parte del sentido de la pacha. Se trata de una racionalidad cósmica, que trasciende la esfera individual o más bien individualista del hombre.

Según el pensamiento andino, estamos integrados al mundo, hacemos parte de él y lo moldeamos. Pero dicho mundo tiene unos principios, unas leyes naturales que lo ordenan conforme al objetivo de conservar precisamente un orden.

El rasgo más fundamental y determinante del pensamiento andino es la relacionalidad de todo. (...) [Para el runa quechua] el universo es ante todo un sistema de entes interrelacionados, dependientes uno de otro, anárquicos, heterónomos, no sustanciales. (...) El principio de relacionalidad se puede formular de manera negativa y positiva. Negativamente dice que no puede haber ningún ente completamente carente de relaciones, y cuando se dice relaciones, hay que pensar en relaciones transeúntes (o trascendentes), y no solamente en relaciones inmanentes (o reflexivas). (...) Positivamente, el principio de relacionalidad dice que cada ente, acontecimiento, estado de conciencia, sentimiento, hecho y posibilidad se halla inmerso en múltiples relaciones con otros "entes", acontecimientos, estados de conciencia, sentimientos, hechos y posibilidades. La realidad (como un todo holístico) recién es (existe) como conjunto de seres y acontecimientos interrelacionados. (...) La relacionalidad, como base trascendental (arjé) de la concepción filosófica andina, se manifiesta en todos los niveles y los campos de la existencia. Por eso puede ser llamada el "axioma inconsciente" de la filosofía andina y la clave preconceptual de la interpretación hermenéutica de la experiencia del runa andino. (Estermann, s.f., p.3-4)

El pensamiento andino contiene un fuerte componente ético de responsabilidad vital. Hace énfasis en una comprensión holística del universo, en el que nada es absoluto en sí mismo, sino que todos los seres, sentimientos, sentidos, están en relación. Por lo tanto, la condición de unos y otros depende de un conjunto de acciones, manifestaciones y situaciones en relación en donde, al hacerse conciencia de ello, surge la responsabilidad como mandato primario de la voluntad del sujeto. La reciprocidad constituye un principio básico de la reconciliación, al contener en sí la fuerza de atracción de los seres siempre en relación. 


\subsection{Antropología y ética de la alteridad}

La reconciliación supone la fundación de una relación basada en el perdón y el reconocimiento del otro para un proyecto de convivencia, donde los lazos sociales se reedifiquen luego de sucesos que han propiciado su quiebre. Se comprende que la reconciliación es un proceso complejo en la medida en que supone no sólo cambios estructurales del orden social bajo el cual se ha comenzado y alimentado el conflicto armado, sino que también implica elementos de orden moral, psicológico, emocional y profundamente subjetivos que pueden generar resistencias para buscar, desear y/o aceptar emprender dicho camino.

Por eso se indaga en el área de la antropología y de la ética en particular, aspectos que permitan comprender las posibilidades de la reconciliación y las reflexiones que logren aportar a la construcción de dicho concepto con toda la carga de sentido que contenga. Este propósito se concreta en un primer momento en la categoría de alteridad. Resulta valioso hacer este análisis, pues la alteridad para la reconciliación se construye sobre los hechos de la negación de alteridad. Entonces cómo fortalecer relaciones sociales de alteridad, cuando ha sido negado el ser, la vida de otros. Cuáles son los desafíos éticos para la reconstrucción del tejido social quebrado por hechos violentos.

La alteridad viene del latín 'alter' que significa “otro". En términos humanos, existe un primer momento de alteridad esencial a la condición del yo, que se presenta cuando el individuo se topa con algo o alguien a quien no reconoce como parte de sí. Es el caso del niño que gateando se tropieza con las piernas de su madre y el mundo le dice: hay algo fuera de ti que no te permite seguir por donde vas. En este sentido, la finitud del yo se encuentra en el otro, la conciencia del límite propio se logra a través del contacto con aquel. En consecuencia, para perfilar lo que es uno mismo, es imprescindible ese contacto que permite sentir el límite de lo propio. La construcción entonces del sí mismo pasa por la relación con el otro, y la vida del ser humano se va desenvolviendo en un sinfín de relaciones en las que es posible su desarrollo y expresión en el mundo. 
Así mismo va sucediendo con la identidad, pues esta se define en la medida en que se presenta una diferencia; la afirmación de uno se da un poco en la negación de lo que no es uno. Pero la alteridad no se limita a entender al otro como dador de límite a un individuo o como posibilidad para el sí mismo en la definición de su identidad. La alteridad trasciende al otro como sí mismo, es decir, como sujeto. En la idea de alteridad que se pretende exponer, no es posible ver al otro como objeto, es fundante la mirada de y al otro como sujeto.

Podríamos señalar la alteridad como una condición antropológica en la medida en que el hombre construye su entorno y todos los sentidos simbólicos y referentes culturales en relación con sus semejantes, en relación con el otro, que para el caso presente es el otro humano, un sujeto. Al referirnos al sujeto aludimos a una condición indispensable para la compresión de lo que se señala, a saber, la voluntad. El sujeto es aquel que es dueño de sus actos y que ejecuta acciones y construye pensamientos a partir del criterio de la voluntad; es su voluntad la que dictamina lo que se hará, lo que se desea, es decir, que el sujeto decide y no se comporta únicamente de manera pasiva o reactiva, sino que da de sí a partir de lo que es como voluntad. Hay que descartar entonces la definición de sujeto como que está amarrado a algo, como que depende de la voluntad de otros o de las situaciones sin más. Entonces el sujeto como voluntad se encuentra con otras voluntades, se encuentra en relación y en relación construye su vida. Ahora bien, la cuestión es qué tipo de relación puede lograr la vida en su máxima expresión y buscando las condiciones para que los sujetos se desarrollen en lo que de sí pueden ser.

Acá se quiere proponer un tipo específico pero no cerrado de forma de relación, que más que abarcarse de modo conceptual, plantea más bien un principio básico para erigir las relaciones sociales, en el que el yo descubre al otro y lo valora como sujeto, entendiendo el valor de lo que eso significa y respetando desde la diferencia y la identidad todo el ser que es, edificando una relación intersubjetiva, esto es, entre sujetos.

Siendo una relación entre sujetos, la alteridad en principio se puede dar desde dos posiciones, por un lado, desde la dimensión del otro a partir de uno, y por otro lado, en la dimensión del otro a partir de su sí mismo. En la primera el otro es descubierto por el yo, a partir de la conciencia de sí mismo como sujeto. Según lo planteado hasta aquí, la forma de descubrimiento podría ser la 
extrapolación del sí mismo hacia el otro, es decir, que a partir de la conciencia que tiene el sujeto de sí mismo, encuentra al otro como sujeto por ser semejante. A través del lenguaje, el sujeto puede entablar encuentros con el otro, entendimiento y disertación. En esta misma medida, a partir de algo universal en lo humano como lo es el dolor, el sufrimiento, el sujeto puede sentir compasión y desear el bien al otro, puede querer evitar su dolor y ser parte de su felicidad. Se trata de una ampliación de la individualidad a una comprensión más universal, pero partiendo de la individualidad misma. Es querer para el otro lo que deseo para mí mismo, en la medida en que lo descubro desde mi conciencia como yo.

Sin embargo, aunque a primera vista esta dimensión parezca aportar al concepto que aquí buscamos de alteridad, encierra en sí misma unos riesgos que es preciso superar. Este riesgo es que el descubrimiento que el yo hace del otro no necesariamente es desde la comprensión de sujeto que se ha expuesto. Precisamente el conflicto armado es una muestra de esto. Pues un sujeto tal descubre a otro, pero lo descubre como estorbo, por ejemplo, para su empresa política o como obstáculo para sus intereses económicos. En ese sentido, el descubrir el otro, es el acto primero de la negación de su ser, pues de entrada se le está viendo como objeto, más no como sujeto. El otro no supone de inmediato el sujeto, pues primero que aquel está el yo que define, que señala, que descubre. Poner como principio al yo como descubridor deja abierta la puerta de la negación de la subjetividad del otro en sus distintas extensiones y limita la relación a lo que ese yo comprenda como ser humano, como sujeto que debe ser, pudiendo identificar lo otro como objeto, como cosa, como diferente de manera radical a pesar de las semejanzas evidentes.

La negación de la alteridad en el conflicto armado pasa por todo un cambio mental frente a lo humano. Estudios se han llevado a cabo en este sentido, por la preocupación de algunos académicos en torno a la incomprensión de las atrocidades cometidas, por ejemplo, en las masacres ejecutadas por grupos paramilitares. Esas búsquedas y algunas investigaciones judiciales han planteado que, como parte de los entrenamientos de paramilitares se desarrollan toda una serie de actividades militares e instructivas de alto impacto psicológico encaminadas a trasfigurar la concepción de lo humano. En esos ejercicios la finalidad es convertir, dentro del entrenado, la concepción de hombre a un sentido de animal o de cosa. Se trata de la animalización del humano o de su cosificación, con el fin de que el asesino no sienta ni miedo, ni 
culpa, ni compasión a la hora de asesinar y rematar a sus víctimas. Esta trasfiguración inducida de todos modos da cuenta de que en el ser humano hay sentimientos de alteridad, pero que en medio de la guerra, estos son reconfigurados en actitudes y acciones negadoras de aquella.

De ahí que sea necesario explorar en la segunda dimensión de posibilidad de la alteridad: la dimensión del otro a partir de su sí mismo. Esto impone una nueva concepción antropológica del hombre que se define no en la libertad absoluta del ser, sino en su carácter de reciprocidad, de relación constante y constitutiva con los demás. Es pues la superación del yo como definidor, para darle paso al otro como constitutivo de lo propio en una calificación de un 'nosotros'. En este sentido, el otro es y está antes que el yo, o sea, que tiene existencia, y por lo tanto, el otro se nos presenta como ya dado, como valor y como dador de sentido al yo en un sentido parcial y no total, pues el yo mantiene su voluntad como sujeto.

Este es pues un giro ontológico, en el que la existencia del otro es el principio regulador de la concepción humana, por encima de su ser y del ser del yo. Esto quiere decir que antes de las aspiraciones o acciones que uno emprenda, ya existe un otro al cual tanto en sentido antropológico como ético se le debe como vida, como sujeto. El otro no sería más un descubrimiento del yo, sino que sería existencia anterior como sujeto a la percepción que de él se pueda formar el yo. Entender al otro como otro en sí mismo, es decir, a partir de su existencia, no deja espacio para negarlo, pues su estar es independiente de la concepción que tenga el yo sobre su sí mismo. Esta dimensión de la alteridad contiene un fuerte sentido ético.

Dicho sentido representa el principio estricto de la democracia, que podríamos denominar rápidamente alteridad política, significando la tolerancia y la posibilidad que tendrían garantizados los ciudadanos de hacer política en un sistema político abierto, plural y garantista. En este sentido, se comprende que uno de los elementos claves tanto de los acuerdos de paz entre actores armados y el Estado, y en el tejido social como tal, para restablecer o bien re fundar una entidad política que busque superar las causas del conflicto armado y las asimetrías sociales que lo alimentan, será la garantía de la participación y la acción política civil. En la medida en que se reconozca de parte de las instituciones públicas y de los mismos ciudadanos el principio de alteridad tanto en el sentido de la humanidad que se ha desarrollado anteriormente, como en su 
sentido político, se podrá avanzar en la constitución de un orden político en el que el respeto de la diferencia sea fuente de interacción política por fuera del conflicto armado, o bien, una práctica política en el sentido del diálogo, el disenso y el consenso.

De hecho, la negación de la alteridad en el conflicto armado se evidencia con suficiente frecuencia, o más bien, es constitutiva del mismo conflicto, en la medida en que un actor busca eliminar físicamente la influencia política de otro. Es muy difícil establecer en Colombia una delimitación estricta del ejercicio del poder armado, al ejercicio del poder político en el marco de la civilidad o el Estado de Derecho. Y esta dificultad radica en que las relaciones entre civilidad y guerra son tan estrechas, mezcladas y entrecruzadas, que puede suceder que un fin político se persiga por medios armados, o que para lograr una meta militar se usen instrumentos de Derecho y política. Política y guerra en Colombia son casi una sinergia en algunos actores, como las guerrillas y el Estado. Este último ha asumido una posición de Estado de sitio o Estado de excepción que en vez de ser la excepción como su nombre lo indica, ha sido la regla del ejercicio del poder político de la mayoría de los gobiernos del siglo pasado y el presente. Lo cual pone en cuestión el sentido y la realidad del Estado de Derecho, la democracia, la garantía de los Derechos Humanos y las formas de la ciudadanía en Colombia.

\subsection{Justicia y reparación}

Tal vez uno de los asuntos más difíciles de abordar tanto en el plano filosófico como en el marco de la realidad social es el de la justicia, en tanto que su significado ha variado y no precisa en muchos casos, un contenido unívoco, esto es, un sentido absoluto que se aplique sin distinción de particularidades. Además en el plano social, la justicia es algo que incomoda a quien comete la injusticia en términos de asumir la responsabilidad por lo cometido, esto es, se puede presentar una dificultad grave tanto en la inculpación como en la responsabilidad que deberá resultar en un acto de reparación. Dificulta también la reflexión el hecho de que históricamente no contamos, como pueblos, con un referente real de justicia en términos de una sociedad justa, de un periodo de nuestra historia en el que la sociedad se rija por ideas y prácticas de justicia. Para adentrarnos en el tema de la justicia y su relación con el sentido de la reparación, en el marco de la 
reconciliación, será presto iniciar con una serie de cuestiones que suscitan un ejercicio reflexivo en torno a las mismas en proyección con el presente objeto de investigación. Empecemos pues por ¿qué es justicia, o qué es la justicia?, ¿por qué hablar de justicia en un proceso de reconciliación?, ¿cómo será entonces la justicia en dicho proceso?, ¿es compatible o que dificultades plantea la relación paz/justicia?, a modo general, ¿qué tipos de justicia existe?, ¿a qué se refiere la “justicia de las víctimas”?

Para abordar estas cuestiones se propone una estructura de escrito: primero, presentar a grandes rasgos la definición del tratamiento filosófico de algunos pensadores clásicos y contemporáneos que abordan el tema de la justicia, ya sea como cuestión central de sus obras o como parte constitutiva o anexa de las mismas. En un segundo momento se presentará la propuesta que hace Reyes Mate sobre la justicia de las víctimas o la justicia anamnética, que se considera un aporte fundamental en la construcción de una concepción de justicia para el proceso de la reconciliación y los escenarios de posconflicto, y que nos lleva a establecer la relación entre justicia y reparación que aquí se pretende. Lo anterior aportará un panorama amplio de las consideraciones en torno a la justicia, y eso con el fin de tener algunas claridades y referentes para elaborar una propuesta de justicia en clave de reparación.

Antes de asumir este propósito, se plantea una reflexión en torno a la importancia de la justicia en un proceso de reconciliación y en la construcción misma de su concepto (del de la reconciliación). Partimos de un hecho esencial: en un conflicto armado, lo que es, en las dinámicas propias de la guerra (en tanto enfrentamiento armado entre dos o más contendientes con presencia de población civil), se cometen injusticas por doquier. Bueno, esta afirmación supone que de hecho ya partimos de una concepción de justicia y por tanto de la afirmación de que algo llamado justicia existe. Ahora, como se pretende ir construyendo dicho sentido, se asumirá el riesgo de la afirmación, sin entrar en detalles. Entonces, en el conflicto armado, que de hecho encuentra algunas de sus causa en actos de injusticia, y que a lo largo de su historia se alimenta de y reproduce a la vez injusticias, es considerable proponer, en un posible escenario de posconflicto o de fin del conflicto armado, la justicia no sólo como una exigencia en el proceso de paz, sino como una condición sine qua non del nuevo escenario social, del proceso de 
reconciliación. Por simple (en realidad compleja) inversión de la situación, se afirma la justicia sobre las injusticias vividas.

La justicia se constituye en parte de la esencia misma de la construcción de paz, de la vivencia de la paz, de un orden político que se sustenta en los principios de la justicia o bien que ejerce sus funciones en base al principio de la justicia. Así pues, la justicia se va consolidando en una función doble o en dos escenarios significativos: por un lado, la justicia como mecanismo, como instrumento, como medio, y por otro lado, la justicia como principio, como estado, como fundamento, como esencia de un orden político particular. Nos podríamos extender en la justificación del lugar que ocupa la justicia en el proceso de reconciliación, sin embargo, es suficiente por el momento dejar de presente la anterior consideración, a fin de continuar la reflexión con elementos más puntuales que nutrirán el debate y que permitirán retomar estas ideas.

Un esquema muy general de algunas formas de interpretar la justicia, se presentan a continuación. La justicia retributiva se refiere al pago o castigo que debe cumplir quien comete un acto de injusticia. La justicia restaurativa va más allá y supone la reparación del daño. Y la justicia distributiva es una categoría más social en la medida en que consiste en la distribución de bienes, servicios y cargas en la sociedad basados en el principio de la igualdad. La justicia legal se refiere a que los actos de los ciudadanos y gobernante se ajusten a lo prescrito por la ley.

A pesar de que todos los tipos de justicia resultan relevantes, se harán un comentario sobre un tipo de justicia que será tenida en cuenta en la propuesta concreta para la reconciliación en Colombia, sobre todo en el capítulo siguiente en lo referente a la distribución de la tierra y la superación de las desigualdades sociales. La justicia distributiva se ocupa de las condiciones de vida a futuro de la sociedad y en términos concretos, de casos de transición, permite dimensionar los factores estructurales que hicieron parte o provocaron el conflicto armado, y en esta vía, puede entenderse como coexistente con la justicia transicional en escenarios de posconflicto. Teniendo en cuenta que la pobreza, la inequitativa distribución de ingresos, la concentración de la tierra, y la extrema desigualdad social que por décadas ha motivado y regenerado el conflicto armado en Colombia, es necesario considerar la justicia distributiva como avance para el 
mejoramiento de la calidad de vida de los colombianos, como medida hacia la construcción de una sociedad menos desigual, con mejores condiciones de vida y menos violenta. La distribución de bienes, tierra, ingresos y sobre todo, de condiciones para el buen vivir, está en el centro de la reconciliación en Colombia, por la misma génesis y configuración del conflicto armado, además de ser uno de los supuestos de la misma idea de democracia.

Platón expone que la justicia es una condición del alma y que, por tanto, obedece al carácter interno del ser hombre. No es un acto externo sino una condición interna. La justicia es la manifestación del alma en su esencia. Entonces la condición del alma puede ser pervertida por la acción injusta del individuo. El hombre debe cultivar un alma justa y no asistir a las injusticias. Se debe formar el alma de sí y de los otros para ser justos y por ende felices. En otra dirección, Aristóteles (2004), ubica el problema de la justicia en la moral de la virtud. La virtud es un punto medio, una medida que se sitúa entre dos extremos, que son considerados vicios. Las virtudes no son pasiones ni potencias, son hábitos.

La virtud es, por tanto, un hábito selectivo, consistente en una posición intermedia para nosotros, determinada por la razón y tal como la determinaría el hombre prudente. Posición intermedia entre dos vicios, el uno por exceso y el otro por defecto. (...) Según su sustancia y la definición que expresa su esencia, la virtud es medio, pero desde el punto de vista de la perfección y del bien, es extremo. (p.42)

En el marco de la concepción aristotélica de la ley natural que se funda en la razón universal, dice el filósofo:

Divido la ley en particular y en común: particular, la establecida para cada pueblo respecto de él mismo, y ésta es en parte no escrita, y en parte escrita. Común es la ley conforme a la naturaleza. Pues de acuerdo con ésta existe algo comúnmente justo e injusto, lo cual todos adivinan, aunque no exista ningún acuerdo común entre unos y otros pueblos, ni pacto alguno. (Aristóteles, 2005, p.99)

Existe un sentido de justicia particular y uno de justicia total. El primero tiene que ver con el sentido de igualdad que conduce a los actos de distribución (intercambio de bienes), y el segundo 
se refiere al sentido normativo que tiene que ver con todas las relaciones sociales dentro de la comunidad política.

En Santo Tomás (1978), "lo propio de la justicia, entre las demás virtudes, es ordenar (corregir) al hombre en las cosas relativas a otro" (p.7). "Justicia es la perpetua y constante voluntad de dar a cada uno su Derecho" (p.10). La palabra Justicia implica igualdad, por esto, es de esencia de la Justicia el referirse a otro, porque nada es igual a sí, sino a otro. Y puesto que la Justicia es para rectificar los actos humanos, es necesario que esta igualdad que requiere la vida se logre, se restablezca cuando se haya destituido.

Seis siglos después aparece la teoría del capitalismo de Karl Marx. ¿Por qué es importante hablar de Karl Marx? Carlos Marx introduce en el pensamiento del siglo XIX la condición del trabajo como principio de las riquezas. La condición, que constituía el ser obrero, disminuía la condición humana a una degradación y miseria de la vida en medio del comercio voraz del desarrollo capitalista industrial. El trabajo como fuente de poder pone al desnudo la vida del hombre: trabajar o morir, pero siempre se está muriendo por trabajar. En el sentido de la relación que se establece entre capitalista y obrero, se forma una estructura social que demarca fronteras sociales de comportamiento y relación social en términos de explotación del hombre, por lo tanto, la justicia tiene un sentido estrictamente social. Se trata de las condiciones materiales necesarias para el logro del bienestar y el goce de los derechos humanos, sustentados en una forma específica de igualdad en el marco mismo de la relación social, siendo primordial el desarrollo de lo humano, en últimas de lo ciudadano.

Un orden social basado en el principio: a cada cual según su necesidad, y cada quien según su capacidad. Esto correspondía a un análisis de la sociedad alemana del siglo XIX en la época de la industrialización y la tecnificación de la mano de obra empobrecida, que provenían del campo en su mayoría. Se le exigía más al obrero de lo que podía dar y se le daba menos de lo que necesitaba. Por el contrario, el capitalista recibía más de lo que necesitaba y daba menos de lo que podía. La justicia en Marx se lograba cuando cada quien tuviera la condición de satisfacer sus necesidades, en un sentido universal, y lograr el desarrollo libre de la condición humana, en un contexto solidario y comunal. Este sentido comunal es muy parecido a lo que ha ocurrido en 
el continente, pero de un modo distinto, ya que las comunidades indígenas tenían un conocimiento natural de la vida, dado en la experiencia.

Hans Kelsen representa una postura muy subjetiva de la justicia, calificándola de relativa, pues no logra encontrar un principio que la defina de manera unívoca. Kelsen afirma que no se ha logrado una definición absoluta de justicia. El principio que encuentra el político de una forma de justicia es que se da en la democracia como sistema político de libertad e igualdad ante la ley. Kelsen (1992) expone que existen múltiples puntos de vista que definen el alcance y forma de la justicia, y que se definen en relación a un contexto y momento histórico que afirma la existencia de lo justo y lo injusto, siempre en el marco de la comprensión de lo antropológico.

Kelsen (1992) plantea que, "la Justicia es en primer una cualidad posible, pero no necesaria, de un orden social que regula las relaciones mutuas entre los hombres" (p.35). Que en los términos de su pensamiento se ligan a la igualdad de los hombres ante la ley en un sistema político democrático del siglo XX europeo. Continúa hablando del orden social y dice que, "significa que este orden social regula la conducta de los hombres de un modo satisfactorio para todos, es decir, que todos los hombres encuentran en él la felicidad" (p.36). "La búsqueda de la Justicia es la eterna búsqueda de la felicidad humana" (p.36). Si retomamos el pensamiento de Platón, notamos en seguida una relación similar, por lo menos en la enunciación, entre la Justicia y la felicidad humanas. Esta situación la ve posible en el ejercicio de la democracia.

En cuanto a la teoría de Reyes Mate retomaremos lo más esencial de la justicia de las víctimas, o la justicia anamnética. Primero que todo decir, ¿quiénes son víctimas?, o como lo aborda Reyes Mate, ¿cuáles son las características de las víctimas? Reyes Mate advierte que su pensamiento está dirigido a las víctimas de la violencia política, y pone como condición que las víctimas son ante todo inocentes (no es lo mismo morir que ser asesinado), es decir, que su estado es resultado de un acto de injusticia. Las víctimas tienen voz propia, que no debe ser sustituida ni apropiada por otro, y son autoridad moral para constituirse en actor principal en la política en un posible tránsito social reconciliatorio. La condición de víctima se vive por el sufrimiento del hecho violento y contiene una verdad, por lo que sugiere la justicia partiendo de las injusticias sufridas. 
Reyes Mate da un lugar claro a la víctima: reintegrar al verdugo en la humanidad pérdida, por haberse inmerso en la 'zona gris' de la inhumanidad.

Así pues, llegamos al tratamiento de la víctima, que puede ser el camino político: la paz, o el camino mesiánico: la reconciliación. La paz se refiere al imperio de la ley que estuvo sustituido por la arbitrariedad de la violencia; y la reconciliación comprende un proceso profundo de transformación social en el que se superan los odios y se busca el restablecimiento, en términos de convivencia, de las relaciones humanas, basado en el perdón y la superación del terror. La reconciliación deberá tomar como punto de referencia la memoria de las víctimas, que consiste básicamente en la conciencia de la vigencia de los derechos de aquellas, de sus sueños frustrados y de las injusticias cometidas que ponen el acento en la reclamación de justicia sobre lo anterior. Esta actualidad permite hacerle frente al olvido, a la prescripción y a la desesperanza.

La justicia de las víctimas, la justicia anamnética se erige con la memoria y, como propone Reyes Mate, supone una nueva mirada, un nuevo sentido moral frente a la historia, frente a las víctimas y frente a la justicia, donde lo central será no sólo la experiencia, sino también la vigencia del pasado, de los derechos negados. Ante la violencia, la justicia debe constituirse en el fundamento moral de la sociedad; y el lenguaje deberá aportar una nueva sensibilidad y cumplir con su función de nombrar, comunicar y trasmitir al otro. Cuando hablamos de lenguaje será preciso aclarar que no son sólo las palabras y razones concretas, sino que se alude a un universo de símbolos que evocan un universo de sentidos y emociones por manifestarse. Esta propuesta se inserta en dar una nueva mirada y comprensión de la historia, donde las víctimas con su propia voz y, a partir de la autoridad moral que les compete, sean partícipes de su construcción, rompiendo la hegemonía de los vencedores que caracteriza a la historiografía. Este interés se acompaña de la re significación de la igualdad, donde lo que importa es reconocer las diferencias con el otro, desde un postura ética de la alteridad.

Un aporte fundamental sugerido por la justicia de las víctimas es la consideración del tiempo en sentido amplio. La comprensión se enraíza en la concepción de que el pasado no es un tiempo clausurado, siendo posible romper con ciclos de injusticias que se reproducen por el olvido y la impunidad. De otro lado, en contraposición con la abstracción propia de los parámetros de la 
justicia (el crimen, el delito, la pena), la justicia de las víctimas pone atención en la individualidad, en la experiencia de la injusticia como punto de partida de la construcción dadora de significado de la justicia, tomando como epicentro a la víctima, su sufrimiento y su realidad. La justicia anamnética es entonces la justicia del ausente, una justicia de la reparación, de carácter reconstructiva que busca recomponer el bien común que todo crimen destruye. Implica así mismo asumir una responsabilidad histórica, donde las culpas se heredan. Y por último aboga por una memoria salvífica, se salva el sufrimiento del pasado. Pero esta justicia plantea serios dilemas que provocan el debate y la reflexión tanto filosófica como política. Se trata de la inocencia, la no clausura del pasado, el testigo y la autonomía moral de la víctima. Su legado de inscribe en la evocación posible de ¡Perdón pero no olvido!

En el marco de la filosofía latinoamericana, Leopoldo Zea cita a Miró Quesada hablando de la justicia social.

En nuestros días, el filósofo peruano Francisco Miró Quesada hablará también, del hombre, pero del hombre concreto, real, el que más allá de las ciudades hace fructificar los campos. Hasta ahora, dice, sólo hemos hablado del hombre concreto, es el que ahora surge como una realidad amenazante. "Porque se creyó que bastaba hablar de amor por los hombres para amarlos, nos encontramos con hombres de carne y hueso que no nos aman.” De allí el enfrentamiento y de allí la necesidad de la reconciliación. "Si el problema era el desgarramiento inicial, si la solución era la reconciliación, la única salida posible tenía que ser la praxis política encaminada hacia la afirmación de la condición humana." "Y si el desgarramiento consistía en el desconocimiento del ser del indio, la reconciliación tenía que consistir en una afirmación del ser del indio. No para negar al blanco, no para rechazar los grandes y eternos valores heredados de la cultura hispana y occidental, sino sencillamente para integrar lo que desde el comienzo ha sido separado". (Zea, s.f., p.13)

Esta discusión se enmarca en la comprensión del problema ontológico del ser latinoamericano. Es un problema situado que se ha tratado desde la pregunta por la identidad y por la constitución del ser latinoamericano. Se parte de la premisa de la orfandad producto del nacimiento violento del continente. En pocas palabras se afirma que América Latina nace de una madre que es la cultura indígena y del padre encarnado por España. La relación entre ambos es de violencia, 
dominación del padre sobre la madre, razón por la cual el hijo busca afirmarse en la negación de ambas culturas, pues una representa la dominación como ejercicio violento del poder, y la otra se ubica como ser dominado, sometido, violentado. El hijo es expresión no de una fecundidad, sino de una escisión, de una fractura originaria, que se da por la negación expresa, simbólica y física de la cultura madre. Ahora bien, en términos de justicia resulta relevante la asimilación que se hace entre justicia social y reconciliación, y de esta vista como la integración de lo que ha sido separado. Nuevamente, la reconciliación aparece como una formación de la reconstrucción de lazos o tejidos sociales, en este caso, poniendo el acento en la cultura indígena y la cultura occidental. La reconciliación sería la vía a seguir luego de un estado de injusticia, que se evidencia en el texto como negación de la alteridad, como fractura social, como desgarramiento.

La reflexión plantea un reto fundamental en la concepción de reconciliación para el caso concreto colombiano, y tiene que ver con el modo y la dimensión en que se encuadre la reflexión filosófica de los orígenes y dinámicas del conflicto social y armado, pues pone como supuesto de la condición latinoamericana, su origen violento, violentado, un desgarramiento inicial que debe ser reconciliado. Asumir la violencia de la conquista como partera del continente provoca nuevas y profundas reflexiones en distintos órdenes, sobretodo, en términos éticos, epistemológicos y antropológicos, que superan la visión lineal de la historia oficial e invitan a la reconstrucción simbólica del ser latinoamericano, en clave de reparación.

Concluyendo parcialmente, tenemos que la reparación es la vía de lograr la justicia como principio constitutivo del ser, asumiendo la negación de la injusticia y la necesaria reordenación del estado de cosas injusto. Hemos esbozado cómo las injusticias se manifiestan en actos que generan un desequilibrio, y el ánimo reparador consiste en equilibrar, en deshacer lo causado por la injusticia. El mismo desequilibrio se presenta en el hombre, en su entorno, en su mundo. La reparación busca mermar o eliminar los daños causados por un acto injusto. La justicia sólo se logra en el momento en que se establece el equilibrio, la proporción de los elementos y el todo. Y bien, ¿es esto posible?, o más bien, ¿es esto humanamente posible? 


\section{CAPÍTULO III \\ TRANSFORMACIÓN SOCIAL PARA LA RECONCILIACIÓN}

Este capítulo buscar establecer una serie de reflexiones descriptivas de las transformaciones sociales que deberían sucederse para poder avanzar en un proceso de reconciliación. Para eso quisiera esbozar una triada que compondría dicho proceso: transición, pos conflicto y reconciliación. En el capítulo anterior se hizo referencia casi estrictamente a las condiciones subjetivas de la reconciliación, a los actos y voluntades necesarios para asumir un proceso como tal. Este capítulo se acerca al tema de las instituciones, las estructuras sociales y las prácticas que se considera, deben promoverse y de hecho efectuarse para asumir un proceso de reconciliación en Colombia.

El punto de partida para dicho propósito es la reflexión en torno a la política, su concepción y la función de su praxis. En la tradición occidental, la política se ha asumido como la esencia jerárquica y dominadora del ser humano y la sociedad, ya sea sobre otros seres humanos o sobre la naturaleza. La política se erige como afirmación de lo propio, la polis, y negación de lo otro, los pueblos bárbaros, del extranjero como extraño (y por tanto como peligroso). El poder se ha estudiado desde la mirada del poder dominar, poder conquistar, poder ordenar, poder administrar (siempre desde la dimensión de lo mismo, del yo) lo que significa que el hombre políticamente se determine por el logro del fracaso en la guerra y la sumisión del Otro, de lo Otro.

En el sentido menos violento, la política es el espacio de discusión, encuentro y programación de decisiones para la administración de lo público. Lo cual implica la aceptación del otro, pero este otro, no es en sentido total otro, sino que es lo mismo, ya que a la asamblea como lugar idóneo para la política administrativa y gobernativa, acuden ciudadanos, personas capacitadas por las normas culturales y las leyes jurídicas para participar en política. Entonces el otro como ciudadano no es otro, en el sentido que pueda tener el bárbaro de Aristóteles, sino que el otro ciudadano, es lo mismo, es un hombre que pertenece a la comunidad política, y como tal se le escucha y se debate con él. La voluntad dialógica será regla de habitantes de un mismo territorio o espacio político, siempre delimitado dentro de las fronteras de la polis. 
Dussel (2006) argumenta que la dominación en la práctica del poder político obedece a la acción de fetichizar la concepción de lo político y en un modo inmediato del poder. El poder a partir de la modernidad (que se inicia con la invasión de América), se define casi estrictamente como dominación. En este sentido,

La corrupción originaria de lo político, que denominaremos el fetichismo del poder, consiste en que el actor político (los miembros de la comunidad política, sea ciudadano o representante) cree poder afirmar a su propia subjetividad o a la institución en la que cumple alguna función (...) como la sede o la fuente del poder político. (p.13)

La corrupción de lo político obedece a la ruptura que se establece entre el poder político y su fuente primaria que es la comunidad política o como lo tratará Dussel, el pueblo. Sin embargo, existe otra acepción de la política comprendida como la relación intersubjetiva de construcción colectiva del habitad social, mediada por expresiones culturales diversas y multiformes que ofrecen riqueza, a la vez que suponen el reto del diálogo, el encuentro y la comprensión de la condición humana. En este postulado se encuentra como base el concepto de comunidad que traduce en principio como la común unidad. Ahora bien, qué puede ser eso común y a qué tipo de unidad se refiere el ethos comunitario. Lo común se refiere a varios asuntos, entre ellos, dos primarios, la condición humana en la que el ser humano depende de otros seres, y la territorialidad como expresión de un espacio común de creación y recreación cultural.

El ser humano es un ser viviente. Todos los seres vivientes animales son gregarios; el ser humano es originariamente comunitario. En cuanto comunidades siempre acosadas en su vulnerabilidad por la muerte, por la extinción, deben continuamente tener una ancestral tendencia, instinto, querer permanecer en la vida. Este querer-vivir de los seres humanos en comunidad se denomina voluntad. La voluntad-de-vida es la tendencia originaria de todos los seres humanos. (Dussel, 2006, p.23)

La voluntad de vivir sería el motor de la comunidad, pero bien, si los intereses individuales están yuxtapuesto, o si cada quien usa su potencia para hacerse a sus propios fines, se dará un choque de poderes, un encontrón de potencias que aniquila, en la medida en que una acción suponga la 
impotencia, inhabilidad o negación de otra acción. De esta posibilidad, surge la condición de la unidad de la comunidad. La unidad en este sentido se refiere a la confluencia de intereses de los miembros del corpus político, o bien a la capacidad de "sentarse juntos a la mesa" para dirimir conflictos, debatir postulados y proyectar una ruta común de acción. La política en este sentido se presenta como el escenario y la actividad humana en la que los miembros de la comunidad rompen el silencio de la distancia que hay del yo al otro, para acercarse a su existencia, a su pensamiento y a su experiencia, asumiendo desde una concepción ético-política del nosotros, su vida, su estar en el mundo como realidad inmanente.

El motor de vida visto desde la comunidad propone asumir la realidad de coexistencia desde tiempos inmemoriales de los seres humanos, su condición esencialmente social, comunitaria o agregativa, en la que se debe trasponer la voluntad-de-vivir sin más a la voluntad-de-vivir-encomunidad. Lo común de la comunidad no tiene que ver estrictamente con valores culturales, puesto que el concepto no se enraíza exclusivamente en un grupo humano que comparta un territorio local, unas mismas prácticas, o que pertenezca a una misma familia lingüística.

El concepto de comunidad que aquí se propone supera la concepción comunitarista de los grupos humanos localizados y hermanados por algún vínculo accidental o que se haya dado por el misterio divino. La comunidad aquí se refiere al conjunto de los seres humanos, bajo una mirada cosmopolita que supera la dimensión familiar restringida, para abrirse a la posibilidad de diálogo y encuentro planetario, pues lo común de la comunidad es la condición humana en sus múltiples aristas, valores y expresiones culturales posibles y efectivas.

No se pretende descartar la importancia y significado esencialmente fundante de la localidad, la familiaridad y la cultura situada para el proceso de reconciliación. Pues ante todo, se trata de reconstruir territorialidad, de definir nuevos modos de unir o fortalecer relaciones concretas del tejido social. Lo que se dice es que la cultura concreta y diferencial debe ser fuente de diversidad, de riqueza, sin perder de vista las múltiples formas de ser del ser humano y de las sociedades. El territorio puede comprenderse entonces en dos vías: el espacio concreto y a la vez simbólico de la vida de un grupo humano, de un sujeto, de una comunidad en particular, y por otro lado, o simplemente en una dimensión más amplia, como el lugar físico y simbólico de la 
comunidad en sentido general, como conjunto de comunidades locales. En el primer sentido, se pueden ubicar a la vez diversos territorios.

Por ejemplo, como territorio nacional se asume el proceso de reconciliación dentro de las fronteras de lo que se llama hoy Colombia, pero al interior de ese espacio hay millones de territorios en los cuales se debe reconstruir territorialidad que ha sido dañada, desfigurada o violentada por los actos y palabras de la guerra. $\mathrm{Y}$ al mismo tiempo, en la exterioridad de Colombia, hay territorios con los que igualmente se presentaría un reordenamiento de las prácticas políticas, económicas y culturales, en fin, geopolíticas de corte internacional, que re significan las imágenes territoriales y por tanto, de territorialidad. El mismo marco de comprensión se puede aplicar a la categoría de comunidad.

De lo anterior se deduce que la política sería el ejercicio mismo de posconflicto, pues supone la eliminación de la asimetría de dominador-dominado, para poner el lugar de todo sujeto como sujeto político en su esencia y capacidad para el encuentro, la escucha y la palabra. La otredad es la condición sine qua non de la política, pero vista en un marco amplio comunitario de alteridad positiva, de la ética del nosotros, y de un nosotros que está y se debe a un territorio como posibilidad raizal de existencia.

Y en este sentido, un deber básico y fundador de la reconciliación es la escucha a los pueblos que históricamente han sido afectados por la guerra, que han sido acallados, silenciados y se han visto negados por la perversión de la política, o como lo presenta Dussel por el fetichismo del poder y la corrupción de lo político. Este ejercicio de memoria se inscribe en la determinación política de justicia respecto a la historia, el pasado y las situaciones de opresión, con el fin de reconstruir los relatos que nos atraviesan como nación, en un esfuerzo de dignidad y saber colectivo.

En lo que sigue se abordarán estos postulados con mayor detenimiento, planteando asuntos relativos al posconflicto y a las transformaciones necesarias para la reconciliación, destacando el lugar de los sujetos y de las instituciones en la reconstrucción de la política y la sociedad. 


\subsection{Reflexiones generales sobre el posconflicto en Colombia}

La condición básica del tránsito del conflicto al posconflicto es asumir la existencia, dureza y algún margen de temporalidad del conflicto armado. Tanto la experiencia del conflicto armado como la dimensión histórica del mismo, y la consciencia sobre la barbaridad radical de la violencia profunda, sistemática y permanente, son realidades que pueden orientar el deseo de transformación del país y las relaciones interpersonales. En este sentido, un nivel básico y existencial para la superación del conflicto armado, es la concientización social sobre la barbaridad que se ha naturalizado en el devenir histórico colombiano, esto es la banalización y resignación de las violencias. De ahí que la transición sea un movimiento consciente de la sociedad de un estado de cosas a otro, que se puede exigir o asumir por el agotamiento del corpus social que reclama un escenario de paz para su existencia. Ahora bien, es necesario hacer la claridad de que se hace referencia al conflicto armado y no al conflicto en sí mismo, de donde el posconflicto no se asume como la ausencia de conflictos sociales, sino como la superación de la forma bélica para la resolución de conflictos. El posconflicto trata de la posibilidad de tramitar las disputas por la vía no armada, en el ejercicio permanente y voluntario de reconstruir los destrozos producidos por el conflicto armado.

La anterior claridad es importante puesto que se entiende que por la multiplicidad de intereses, pensamientos, posturas ideológicas, memorias y formas de existir, los grupos humanos pueden estar en permanente conflicto. De hecho, también se asume que el conflicto de por sí no es negativo, sino que puede ser el punto de partida para avanzar hacia la construcción colectiva del orden social, asumiendo la diversidad epistemológica, cultural y cognitiva de las comunidades. El acento lo marca es la forma de dirimir los conflictos, rechazando para la construcción de reconciliación, la vía armada, la violencia física, verbal y simbólica que expresa el ánimo de aniquilar al otro para afirmar el propio proyecto político. No se debe caer en el absurdo de la ausencia de conflicto; lo que sí resulta posible, a la vez que necesario, es la comprensión del conflicto como punto de encuentro de la diferencia y no como punto de quiebre. 
Es sobre la diferencia y el conflicto desde donde se puede dar un auténtico encuentro ético de la alteridad y el compartir que se enriquece por la diversidad y la exigencia de oír, atender y ponerse en posición de la otredad. Claro en la similitud también se logra lo anterior, pero no de un modo radical, pues el opuesto invita por su misma esencia a la radicalidad última de ponerse en la posición contraria, de salirse de sí, y vencerse a sí para poder ver al otro. El gran reto de la reconciliación y del proceso del posconflicto es lograr que quienes antes se apuntaban con un arma, ahora dirijan sus fuerzas, estrategias y acciones a la escucha del otro, a ver a los ojos al enemigo, logrando una transición hermenéutica del enemigo al opositor. El rostro del otro como enemigo debe sufrir una mediación en la que la nueva forma de política, así como el perdón, logre transfigurarlo en ciudadano, como otro, como compatriota, copartidario, o bien, como opositor político.

Una de las formas a través de las cuales se llega a un estado de posconflicto es la negociación y el consecuente acuerdo de paz. Aunque también se puede llegar al posconflicto por la derrota militar de uno de los bandos enfrentados, en el presente apartado se presentará la primera forma señalada: el acuerdo, la negociación, como apuesta política integradora de los grupos enfrentados, y sobre todo, por la dimensión que se puede dar a la sociedad en su conjunto en la superación del conflicto. El posconflicto debe ser la atención prestada al grito anhelante de la sociedad por estar en otro estado, valga la redundancia, de un existir en paz.

Es posible que el posconflicto se asuma también como el cese al fuego, la disminución de los enfrentamientos entre ejércitos o grupos armados, en fin, que se relacione con medidas estrictamente militares. Sin embargo, en este trabajo se ha asumido la reconciliación como una apuesta social amplia que pretende abarcar de forma integral la posibilidad de una renovada forma de habitar, de interactuar, de entender al hombre, a la sociedad y a la política. Por lo tanto, siguiendo el nivel de exigencia de dicha apuesta, la comprensión categorial del posconflicto a que nos referimos no es independiente de asuntos complejos como la construcción de paz positiva o el reordenamiento social de acuerdo a principios básicos como la alteridad positiva, el pluralismo cultural y político, la medicación simbólica y dialógica, y la emergencia de pensamientos ocultados y tradicionalmente relegados a la oscuridad epistémica o la calificación herética. 
El posconflicto como transición social consciente, se corresponde con el principio de la memoria y la reconstrucción histórica del devenir colombiano, en la medida en que se hace necesaria la revisión de los elementos, hechos e imaginarios de diversa índole que se pueden juzgar como causas del conflicto armado. Saber por qué ocurrieron las cosas es la condición básica de superación del conflicto armado, con base a esfuerzos dirigidos a la negación de dichos problemas y la afirmación de formas construidas socialmente de asimilación y superación de los mismos. De ahí que las agendas de paz se establezcan de acuerdo a la identificación de problemáticas entendidas como estructurales y constitutivas del conflicto armado. Sin embargo, las agendas de paz no agotan los problemas, dimensiones y percepciones del conjunto de la sociedad sobre las causas o focos que alimentan el conflicto armado, por lo que se hace necesario que la sociedad establezca sus propios escenarios de diálogo discusión, y que enriquezca los encuentros que se llevan a cabo entre los grupos armados o entre los representantes políticos de dichos grupos.

En este sentido, la participación amplia de la sociedad, de los diferentes grupos y comunidades en la construcción del mapeo de las problemáticas sociales y de las posibles rutas de acción para su tratamiento, significa en últimas la configuración de la ciudadanía en el complejo proceso de emergencia de la comunidad política. Y por la misma dimensión poblacional, lo anterior supone un fuerte trabajo local que escale hasta el escenario oficial de la negociación. En este entendido, no basta con que se firmen acuerdos entre las partes en conflicto entendiendo a estas como los ejércitos enfrentados, sino que se hace necesario que los acuerdos sean sociales, incluso localizados, pues dependen de la decisión y acción del conjunto de la sociedad que se ha visto involucrado directa o indirectamente en el conflicto armado, por una u otra razón. Hay que reconocer que el conflicto armado colombiano ha sido constitutivo de la praxis y el ethos de sus habitantes, creando y reproduciendo imaginarios, prácticas, valores y antivalores que configuran tanto la memoria como la potencia. Por lo tanto, pensar en la superación del conflicto, implica pensar en la emergencia de nuevos parámetros conductistas, en nuevas formas de concebir el mundo y en nuevas o renovadas instituciones sociales tanto privadas como públicas que obedezcan a la aspiración de un orden social edificado a partir de los acuerdos y la forma negociada o consensuada de asumir las proximidades y las diferencias. 
De acuerdo a lo anterior, el lugar de la comunidad local para enunciar el deseo de vida y la forma de política, será el lugar privilegiado en la construcción de paz, en la medida en que las decisiones locales logren escalar y tejer espacios e ideas de colectividad más amplios en lo regional para finalmente articularse con lo nacional. Este último nivel es el que tradicionalmente cumple el papel protagónico, pues es en la instancia del gobierno central en donde se llevan a cabo los diálogos de paz. Sin embargo, pretender que la representación se agota en los discursos de los grupos armados enfrentados es un error típico de las negociaciones de paz, en las que el lugar de la sociedad se relega a la posición del espectador o de generador de ideas sin capacidad de decisión. Es fundamental que la sociedad en los distintos niveles se articule a la negociación, que innove en la forma de existencia política, superando la representación por la participación, porque si bien las armas y la violencia son lo constitutivo de la guerra, la exclusión, la marginalidad y la negación del otro como sujeto político, son elementos que la refuerzan.

Es común como en el caso de El Salvador que el período de posguerra sea incluso más violento que el período mismo de la guerra. Esto se debe a que la firma de los acuerdos de paz da vía libre a la reconfiguración del control económico, territorial y poblacional de los lugares de la guerra. Lo que antes era dominado por un grupo ahora puede ser ocupado por otro a través de la modalidad de la delincuencia común. Del mismo modo, puede ser que no todos los miembros de un grupo armado o que sectores del ejército oficial o de un grupo político o económico en particular, estén de acuerdo con el fin del conflicto por vía política o que no se sientan recogidos o no confíen en los acuerdos a que se ha llegado. Otra razón de la exacerbación de la violencia en el posconflicto es lo que ha sucedido en anteriores procesos de paz en Colombia. Tras la firma de los acuerdos y la desmovilización del grupo al margen de la ley, como ocurrió en el caso de las guerrillas liberales a mitad del siglo pasado, se produce un incumplimiento parcial o total de los puntos acordados y se propone la política de seguridad de eliminación del antiguo enemigo, esto es, una vez los guerrilleros entregaron sus armas y se reincorporaron a la vida civil, el ejército oficial asesina a los ex combatientes.

En el posconflicto se enfrenta la sociedad a lo desconocido; se podría decir que el conflicto armado aunque por sí mismo es sorpresivo, emergente, fluctuante, para el caso colombiano, por 
la durabilidad y crudeza con que se ha manifestado y conservado, se ha naturalizado de alguna forma en la consciencia de los ciudadanos. El posconflicto en Colombia sería la novedad, lo desconocido, lo insospechado, y estas características hacen que la desconfianza, la incertidumbre y el desconocimiento para actuar sean una latencia que persuada para que no se asuma. Pero también recobran un lugar preeminente la creatividad, la emergencia, la capacidad de adaptación y reordenación del entorno para desarrollar las aptitudes y proyectos sociales. La reconciliación misma es un acto de creatividad, de creación, en el que se da lugar al no lugar de lo impensable, de lo que escapa de la razón y permite la emoción, la sensibilidad, la conciencia que supera la mera razón calculadora, instrumental. Así como el perdón es un don, diferente a una transacción, la reconciliación supone también una entrega, casi incondicionada, pues se trata de una mediación que se expresa como confianza en el Otro, sea este un victimario, un hermano, una institución. De igual manera, el posconflicto aunque dependa en gran medida de los acuerdos que se establecen desde la razón y la emoción, desde la medición y la proyección, desde lo mesurable y lo impensable, es en la relación última del ser humano, un acto de fe, y en el sentido social un acto de fe mediado por la ética de la comunidad, por la ética de la comunicación o del discurso, que se sustentan en la comprensión de la condición y posibilidad humanas.

Por lo anterior, para evitar la exacerbación de la violencia en el proceso de posconflicto debe asumirse una redefinición del posconflicto mismo y el lugar de la negociación y los acuerdos de paz. En este sentido, la carga reposa fundamentalmente sobre el Estado como responsable de la garantía de los derechos humanos de los ciudadanos, y consiste básicamente en dirigir los esfuerzos administrativos, la voluntad política y los recursos nacionales hacia dicha responsabilidad. Más específicamente, ¿qué quiere decir esto? En Colombia, una de las causas del conflicto armado es la ausencia, precariedad o cooptación del Estado por parte de grupos privados, y la falta de garantías para la defensa de los derechos humanos, así como la extrema pobreza y la dificultad radical que implica vivir. De ahí que en los acuerdos de paz se ponga sobre la mesa la condición de promoción de políticas que garanticen el acceso a recursos de distinta índole, como mejoramiento de las oportunidades y capacidades para el vivir, bajo principios como la dignidad humana y el bienestar. Entonces, el Estado que desde una comprensión normativa tiene una deuda histórica con la sociedad, debe asumir estos presupuestos de bienestar y dignidad humana siendo que, a la vez que negocia con el grupo 
armado, dirija su esfuerzo político a garantizar los derechos humanos, no sólo para cumplir con la razón de Estado y justificar su aparato burocrático, sino también para crear un ambiente de bienestar que seduzca a la paz y prevenga futuros enfrentamientos o el recrudecimiento de la violencia en el posconflicto.

La deuda histórica del Estado consiste en último término en que el Estado en Colombia no se da como se pretende en la teoría contractual en la que los ciudadanos se constituyen como negociadores de acuerdos en los que se cede parte de la libertad personal a un tercero institucional el cual tiene su esencia en la potencia de dirigir la estructura organizativa hacia la función del bien público o el interés común. Es preciso desmitificar la superioridad moral del Estado y reconocer las prácticas de sus distintos niveles y funcionarios para develar en qué medida el Estado ha sido un garante de los derechos humanos, o si por el contrario deba considerársele un victimario, con el fin de dar orientación en la pregunta de ¿cuál es la función del Estado en el posconflicto? Y por otro lado, ¿cómo deben ser las relaciones ciudadanía Estado en la reconstrucción social del país?

El asunto es importante si consideramos por ejemplo el discurso de la reparación y el lugar de la práctica de reparación en asuntos claves del posconflicto como la justicia transicional y los derechos de las víctimas. Cuando se hace una revisión de la oferta institucional del Estado en lo referente a la reparación de las víctimas del conflicto armado colombiano, como en el caso de la Ley de Justicia y Paz de 2005 o el caso de la Ley de Víctimas de 2011, se encuentra que la mayoría de medidas de reparación obedece a asuntos tales como, acceso a la educación, creación de vivienda, mejoramiento de infraestructura, entre otros, elementos todos que en Derecho Constitucional colombiano pertenecen al ámbito de los derechos sociales, económicos y culturales. Esto es problemático en la medida en que el Estado confunde medidas de reparación con derechos sociales. Entonces ¿para acceder a la garantía de los derechos en Colombia se debe ser víctima? No se debe supeditar la garantía de los derechos a la pertenencia a la categoría de víctima, sino que ante todo se debe reconocer la precariedad del Estado en términos de garantía de derechos, sin negar por esta acotación las medidas de reparación a las víctimas del conflicto armado. 
Desde otra posición de sujeto, sucede lo mismo con el victimario y las medidas que se adoptan en el proceso de desmovilización, desarme y reinserción, sobre todo en la proyección de la reinserción, donde se establecen políticas de auxilio para el bienestar y efectiva reincorporación a la vida civil de los ex combatientes. Dichas medidas versan sobre el empleo, la vivienda, auxilios financieros, educación, entre otras, que del mismo modo corresponden con los derechos socioeconómicos consagrados en la Constitución Política de 1991. No se pretende negar la importancia de estas medidas tanto para la reparación de las víctimas como para la reinserción de los ex combatientes, sino que se propone hacer notar la desviación en la concepción de las mismas y de los derechos socioeconómicos en las políticas transicionales en Colombia, poniendo el acento en que no deben confundirse, y en que no se puede permitir que el discurso transicional acapare la única vía del acceso a la garantía de los derechos de los ciudadanos.

Por otra parte, es preciso proponer que los estudios poscoloniales pueden ser una puerta intelectual importante para avanzar en la discusión del posconflicto, ya que la construcción de paz en el horizonte de comprensión de la reconciliación como se ha venido planteando, presupone unos principios políticos fundantes como la soberanía, la autonomía, la autodeterminación de los pueblos, la defensa de la territorialidad y la participación desde la libertad del pensar y el decir. El proceso del posconflicto en el marco amplio de la reconciliación en Colombia es el escenario político-social en el que se redefinen las relaciones de poder no sólo al interior del país, sino también en la geopolítica mundial. En este propósito, la decolonialidad del saber es un requisito para asumir la voz propia de los grupos culturales del país, de los cuales se nutriría la concepción de la política, de los valores comunitarios y del sentido mismo de la vida. En el posconflicto se deben asumir las distintas formas de conflicto, como por ejemplo, el conflicto epistémico, los conflictos económicos que se dan por la imposición de ciertas prácticas productivas que atentan contra el bienestar de las comunidades, las prácticas de homogenización cultural que niegan la diversidad, los conflictos educativos que proponen una pedagógica dogmática anti liberadora, entre otros. En este sentido, el posconflicto puede entenderse asimismo como una práctica de liberación en la medida en que la sociedad asume el proyecto de autoconocimiento para sanar el pasado y darle un rumbo consensuado al devenir. 
De otro lado, se tiene que el posconflicto debe asumir críticamente las razones históricas y contingentes de la violencia física, política y simbólica, y no centrarse únicamente en el anhelado cese al fuego. En el centro de la discusión política y social es fundamental asumir que la realidad bélica del país se debe tanto a situaciones emocionales radicales de la constitución del sujeto, como a condiciones o falta de condiciones materiales para la vida digna, y en este sentido, la guerra no sólo debe comprenderse a partir de miradas sobre la estrategia, las ocupaciones territoriales, la destrucción, sino que debe entenderse desde el origen profundo y humano del acto y la organización guerrerista, ubicando los escenarios físicos y simbólicos de predisposición a la guerra.

Dentro de las razones históricas del conflicto armado colombiano se pueden identificar rápidamente algunas: la constitución conquistada del país (y en sentido amplio del continente americano), que trajo entre muchas consecuencias la esencia huérfana de la cultura y la hibridación violenta de grupos humanos; la formación social sustentada en la desigualdad, la marginalidad, el dominio y la negación del Otro; el carácter dominador de la política en las múltiples formaciones administrativas e ideológicas; la permanente conquista de las culturas, pueblos y mentalidades de grupos no pertenecientes a la cultura europea y norteamericana; la indefensión simbólica de las tradiciones y ancestralidades ante la imposición violenta y negadora de culturas ajenas; la concepción de una económica para la acumulación de riquezas y de la propiedad privada como sustento del estatus social y la dignidad humana; la subordinación de la económica a los intereses extranjeros; la acumulación y concentración de la propiedad rural a costa del despojo de tierras; el desplazamiento forzado de habitantes rurales hacia los centros urbanos en condiciones de pobreza y desamparo estatal; la creación de estructuras políticas, jurídicas y militares para el servicio de grupos de poder que han logrado anclarse en las posiciones de poder; la negación epistemológica de los saberes ancestrales y de grupos étnicos como los afro descendientes, indígenas y grupos sociales como los campesinos y la cultura popular.

La superación del conflicto armado pasa por la asimilación crítica y propositiva frente a las prácticas e ideologías de colonialidad que perduran en la composición social del país, pues precisamente en la historia de la conquista, el colonialismo y la continua dependencia respecto 
de poderes centrales, se encuentra la raíz de la discordia, el abandono del ser humano y la generalización de la violencia, las continuas guerras por el control político y la hegemonía territorial han impedido la práctica ética del reconocimiento del Otro como parte del sí mismo, y la política oficial se ha debatido entre la negación de lo propio y la redición de culto a lo ajeno, por lo que el ejercicio de lo público ha consistido de modo general, en el control de la población en aras de desarrollar proyectos privados que se presentan ante la ciudadanía como el bien común. En este sentido, ha habido una preeminencia del interés económico acumulativo sobre el poder político del gobierno y la clase política colombiana ha superpuesto el interés privado sobre el colectivo, a la vez que implementa medidas para impedir la autogestión de los territorios, la soberanía local de las comunidades menos favorecidas y el autogobierno. De ahí que la liberación de las estructuras políticas, de la mentalidad económica, y de la existencia y diversidad cultural constituyan las bases fundantes de un nuevo orden social en clave de posconflicto.

Por otra parte, uno de los asuntos centrales del posconflicto es la re significación de las categorías de víctimas y de victimario, puesto que para asumir las políticas transicionales y las normas jurídicas respecto del tratamiento de unos y otros, será preciso incitar una comprensión histórica de ambas posiciones de sujeto. Este es un asunto muy problemático puesto que en medio de la guerra, de sus dinámicas y causas, se ha presentado un tránsito entre quien siendo víctima pasa a ser victimario. Respecto a esto se puede decir inicialmente que las condiciones materiales de pobreza, la exclusión política y la imposición jurídica de leyes y normas antidemocráticas, han generado a lo largo de la historia colombiana un límite a la libertad y voluntad de muchos ciudadanos.

La negación misma de la ciudadanía que se manifiesta entre otras en la falta de garantía de los derechos humanos, civiles y políticos, sociales y económicos, ha configurado un escenario en el que la vía armada y el desarrollo de actividades ilícitas han sido la alternativa para la adquisición de los bienes materiales e incluso para la defensa misma de la vida. En este orden, el sujeto se ha visto absorbido por la violencia generalizada, y por la falta de oportunidades para subsistir, por lo cual, se ha insertado de una u otra forma en las dinámicas de la guerra y de la ilegalidad. Lo anterior no pretende justificar el mal ni los actos que han atentado contra otros, sino que se trata 
de poner el debate sobre la culpabilidad y la responsabilidad de modo diferenciado sobre la categoría del victimario para lograr una postura medida sobre el mismo.

Las categorías de responsabilidad y culpabilidad abren un debate necesario a la hora de asumir el posconflicto como un proceso colectivo de superación del conflicto armado y construcción de paz positiva. Es posible distinguir la dimensión de culpabilidad de los hechos violentos cometidos por miles de combatientes, de la dimensión de responsabilidad, en la medida de la pertenencia a los grupos armados y la afirmación de la guerra. De algún modo, el conflicto armado colombiano fue creciendo, expandiéndose por las distintas regiones y zonas del país, de modo que los habitantes fueron siendo víctimas de atropellos, abusos, violencias y amenazas, y poco a poco se fueron involucrando o fueron arrastrados a enlistar las diversas ramificaciones de la guerra. En este sentido, se puede comprender la culpabilidad pero no la responsabilidad por la guerra misma, y esta diferenciación histórica permite abrir el escenario de la hermenéutica ética

para el perdón y la reinserción de los ex combatientes. No es una regla que se pueda generalizar y en esto consiste el reto institucional y social de caracterizar diferenciadamente los casos concretos, pero si es una condición que debe ser tenida en cuenta a la hora de definir las categorías de las distintas posiciones de sujeto para el posconflicto.

\subsection{Temas y propuestas fundamentales para la reconciliación en Colombia}

En este apartado se presentan reflexiones que versan sobre algunos asuntos fundamentales para la reconciliación en Colombia desde una perspectiva institucional, política y cultural, así como de justicia transicional que cuestionen niveles de concepción y operación para la transición al posconflicto en Colombia. Teniendo en cuenta la vastedad de asuntos posibles por tratar, se asumirán los siguientes por su significación en los discursos y prácticas políticas tanto de los gobiernos nacionales como de las guerrillas y del movimiento social colombiano, así como su trascendencia en la construcción del orden social en general; estos son: tierra y territorio, participación política y democracia, y justicia transicional y derechos de las víctimas. Se continúa con el planteamiento de que la efectividad y durabilidad de los acuerdos de paz en los distintos niveles de la sociedad dependen en gran medida de la atención que se preste a las 
condiciones económicas, culturales y políticas de la sociedad en general y de los ex combatientes y las víctimas en particular. Si las condiciones sociales no sufren un cambio radical que apunte a la reestructuración del país para la paz, poco provecho en términos de reconciliación se podrá esperar de los acuerdos políticos a que lleguen las partes negociadoras.

Tierra y territorio. Una de las causas estructurales del conflicto armado colombiano tiene que ver con el problema de concentración y acumulación de tierra a costa de prácticas y estrategias de despojo, desplazamiento forzado y usurpación, lo que se traduce en una relación inequitativa, excluyente y desproporcional en la tenencia y uso de la tierra. Por esta razón, es pertinente hacer un acercamiento a la cuestión de la tierra en Colombia, teniendo en cuenta los distintos sentidos que pueda tener el concepto y en últimas indagar por la relación entre posconflicto, reconciliación y el tema agrario. Se presenta entonces un esbozo de los sentidos de la tierra y el territorio, para luego dar paso a una serie de reflexiones en torno a las condiciones sociales, políticas, económicas y jurídicas que deben ser tenidas en cuenta a la hora de pensar en el problema de la tierra en Colombia en clave de posconflicto y reconciliación. El propósito de presentar estos elementos es asumir crítica y de forma diversa algunos sentires y saberes que deben entrar en diálogo en un escenario de negociación de la paz en Colombia, siendo que son cuestiones que constituyen parte sustancial de las problemáticas actuales y pasadas del país, y que según como sean asumidas, dependerá el posible futuro de reconciliación.

La tierra y el territorio son espacios que van determinando el carácter y posibilidades de vivir, por lo que comprenden en alguna medida el fundamento como raíz y espacialidad de la vida personal y en común unidad. Del modo como el mestizaje latinoamericano contiene en sí mismo la diversidad cultural de pensamiento sobre el mundo, la vida y las relaciones sociales, es posible establecer algunas consideraciones sobre la concepción sobre estas categorías constitutivas de lo humano y lo social, en clave de reconciliación. Para iniciar se dirá que existe una diferencia entre la tierra y el territorio, en tanto que la primera obedece a la dimensión físico espacial del suelo rural, mientras que el territorio la abarca y además comprende la dimensión simbólica y cultural del espacio habitado. Aunque esta distinción no es tan clara en algunas comunidades sobre todo en indígenas y afro descendientes en los que la tierra puede significar lo físico y a la vez lo sagrado, lo cultural. 
La noción "tierra" es un concepto amplio y ambiguo que termina denominando simplemente un bien representado en un espacio geográfico delimitado, susceptible de propiedad privada o colectiva y al que se le asignan múltiples usos, la mayoría de explotación económica. La noción de "territorialidad" en cambio se relaciona estrechamente con las formas culturales de apropiación material y simbólica de las tierras que pueblos originarios han habitado históricamente, y las cuales tienen significado, no sólo por brindar los medios para la subsistencia sino además porque son el soporte en el cual las comunidades tradicionales desarrollan sus identidades y sus visiones del mundo. (Herreño, 2004, p.249-250)

La tierra puede entenderse a partir de las definiciones que ha establecido la economía política como factor de producción, siendo uno de los elementos centrales para el desarrollo económico de una nación. La tierra representa en este sentido poder y riqueza, tanto desde un ejercicio de la acumulación, como de la explotación. De este último sentido, la tierra puede ser utilizada para diversas prácticas económicas, entre ellas, las más comunes en Colombia son la minería, la extracción de petróleo, explotación de otros recursos naturales (como la madera), la ganadería, la agroindustria y la agricultura. La visión clásica de la economía define la tierra como uno de los tres factores de producción, situándola al lado del capital y del trabajo. La tierra será entonces el suelo terrestre, el subsuelo con los recursos que allí sean explotables y la órbita geoestacionaria. En este orden conceptual, la tierra tiene su lugar en el mundo como despensa para uso y provecho del ser humano, y la ética que se erija desde ahí es la del trabajo, la acumulación, la explotación y el 'aprovechamiento' de los recursos. El carácter y lugar del ser humano se determinará por un constante yo conquisto.

Por otro lado, existe una concepción de la tierra como espacio físico con una fuerte carga simbólica en la que se contiene la vida cultural y lo sagrado como parte constitutiva del ser humano y la comunidad. La tierra es el lugar donde es posible la vida, las relaciones sociales, la relación con la naturaleza, el ejercicio del trabajo como realización y creación humana, y el descanso de los muertos. Este último aspecto es muy valioso sobre todo para las comunidades indígenas y afrodescendientes que conservan la tradición de relación profunda con los antepasados, los cuales a la hora de morir son enterrados en el mismo espacio vital de la comunidad, pues los ancestros representan la guía y la luz de la comunidad, por lo que, aunque 
estén es otra esfera de la vida, siguen siendo parte de la comunidad, razón por la que se justifica su permanencia en el territorio. En esta perspectiva, la tierra representa mucho más que un valor económico en términos de la producción capitalista y la explotación, puesto que lo que se juega en ella son los sentidos de la vida, los símbolos de lo sagrado, el fundamento raigal de la comunidad y la esperanza de futuro.

La tierra es así mismo el espacio vital en el que es posible darse alimento y emplear la fuerza de trabajo para proveerse medios suficientes para la satisfacción de las necesidades de la familia. En este orden de ideas, por ejemplo, el sentido de vida como fundamento existencial y experiencial del campesino es el trabajo de la tierra, que le permite llevar una vida digna y resistir el sufrimiento, la humillación y la precariedad que puede significar la vida urbana, específicamente para los que han sido víctimas del desplazamiento forzado. El ser campesino es la producción limpia para el consumo de los conciudadanos. Al mismo tiempo la tierra es sabiduría, enseña al ser humano y lo orienta éticamente en sus relaciones con el entorno y con el Otro.

Juan Carlos Scannone, filósofo argentino, plantea que en América Latina y propiamente en la sabiduría popular, la categoría "tierra" se aborda en un sentido numinoso como Madre Tierra, como raíz sagrada en la que el pueblo está enraizado fundamentalmente bajo los símbolos propios de su cultura. La tierra es el símbolo de lo sagrado, y como símbolo contiene en sí mismo un logos inteligible y en parte inagotable. El carácter simbólico de la tierra es numinoso, la comprende como materna, sagrada, es una dimensión ctónica. Entonces, en la medida en que se refiere a la comunidad como el pueblo, la tierra es religiosidad y símbolo del misterio de Dios que se concreta como centro del nosotros, conteniendo en sí todo el sentido trascendental de Dios sobre todo hacia abajo, como raíz sagrada y por ende misteriosa de su estar. "Dios se manifiesta y comunica al nosotros en cuanto sujeto ético y religioso. Y se le comunica en y a través del symbolon, por medio del cual Él se une al nosotros en la tierra" (Scannone, 1984, p.69). La tierra como Pacha Mama es aquello irreductible e irreductiblemente religioso del símbolo que expresa lo Absoluto, a la vez que es el espacio del nosotros como posibilidad ética situada raigalmente en el suelo común materno y sagrado. La tierra es el símbolo de lo religioso, del logos de lo sagrado y de la ética del estar en común. 
El territorio de forma complementaria representa el espacio simbólico por excelencia del sentido cultural de los sujetos y las comunidades en términos de organización, lucha y defensa de lo propio. Y en esta medida, la lucha por el territorio es la lucha por la vida misma, puesto que la vida se da en la expresión de las costumbres y los rituales tradicionales que constituyen el fundamento vital. En este sentido,

La acepción del "territorio" si bien conserva un marcado carácter cultural, su esencia determinante es política pues ha servido para defender el ejercicio de la autonomía por parte de las comunidades originarias frente a la institucionalidad estatal y a la sociedad mayoritaria, concretándose para ello en la demarcación de áreas territoriales en las cuales los pueblos étnicos pueden desarrollar sus proyectos de vida. (Herreño, 2004, p.250)

La construcción de territorialidad define el carácter humano y representa la memoria como valor compartido del recuerdo ancestral y de la sabiduría inmemorial. El territorio es así mismo el lugar de la autoridad y el ejercicio del poder. Y en esta vía, el territorio en la teoría del Estado es el espacio con una población sobre el cual se ejerce la soberanía. Se pueden identificar entonces varias miradas sobre la tierra y el territorio que deben ser tenidas en cuenta en las discusiones sobre la transición en Colombia, precisamente porque el problema de la tierra y la ausencia de un discurso histórico e incluyente sobre el territorio han sido estructuralmente foco de disputa y detonadores de conflictos armados por el control territorial, la acumulación y reconquista de la tierra y la definición hegemónica de saberes culturales y éticos sobre el habitar y la económica nacional.

Ahora bien, para hacer referencia a la relación entre el problema de la tierra y el proceso de reconciliación en Colombia, se abordarán cuatro aspectos que se consideran fundamentales a la hora de repensar el orden social, político, económico y cultural del país en un escenario de posconflicto, a saber, redistribución de la tierra, soberanía alimentaria, protección de los derechos de los pueblos indígenas y de las comunidades negras sobre el territorio, y alternativas de desarrollo rural. Si bien son asuntos que no abarcan la totalidad de la problemática en torno a la tierra y el territorio, si pueden constituirse en principios organizativos para irle dando un tratamiento que aporte a la construcción de una paz sostenible. 
El primer punto a abordar es la redistribución de la tierra, que se propone como el ejercicio político, administrativo y jurídico de distribuir con base en principios de equidad e igualdad social, la propiedad de la tierra para la tenencia, uso y disfrute de los colombianos. Esta propuesta se basa en dos premisas concretas. Por un lado, en el punto de partida actual que versa sobre la alta concentración de la tierra en pocas manos y la consecuente desigualdad social que desde allí se genera.

La concentración de la tierra y la desigualdad han crecido en la última década en el campo. El índice Gini rural, que mide la desigualdad, pasó de 0,74 a 0,88. La mayor concentración de la tierra está en Córdoba y Caquetá, según el Cede, de la Universidad de los Andes. La mayor desigualdad está en Antioquia y Valle. La mayor concentración de la propiedad está en las zonas ganaderas y en las que se explotan recursos naturales. La mayor concentración de la tierra está asociada a mayor persistencia de los mismos grupos políticos, es decir, donde el sistema democrático está capturado por grupos de interés. (Revista Semana, 2012)

Y de otro lado, se sustenta en el derecho a la tierra de que deben gozar los ciudadanos, esto es, el derecho al acceso, tenencia, uso y usufructo sobre la propiedad de la tierra (El artículo 64 de la Constitución política de Colombia de 1991 dicta que, es deber del Estado promover el acceso progresivo a la propiedad de la tierra de los trabajadores agrarios, en forma individual o asociativa, y a los servicios de educación, salud, vivienda, seguridad social, recreación, crédito, comunicaciones, comercialización de los productos, asistencia técnica y empresarial, con el fin de mejorar el ingreso y calidad de vida de los campesinos). Se parte de una dimensión real del orden vigente actual y de la normatividad que aunque vigente, no resulta siempre real, en la medida en que no se garantiza en su totalidad el derecho a la tierra, sino que por el contrario, lo que se evidencia en Colombia, es la acelerada concentración de tierras en grandes capitales nacionales e internacionales o trasnacionales. Se trata entonces de cerrar la brecha entre los grandes propietarios de tierra y quienes tienen poca o nada, a la vez que se proveen nuevas condiciones para el mejoramiento de la calidad de vida de campesinos, indígenas, afrodescendientes, desplazados, trabajadores del agro, siendo una tarea central la protección de la pequeña y mediana propiedad y el progresivo acceso a la tierra de los ciudadanos. 
La redistribución de la tierra supone el reordenamiento del territorio nacional, y debe asumir la cuestión sobre la vocación y uso de la tierra. En este sentido, se propone que uno de los ejes que debe ser trasversal a la cuestión agraria en Colombia con miras a lograr un orden social en el que se promuevan la paz y la reconciliación, debe ser lo que se ha trabajado como la soberanía alimentaria. 'Sin pan no hay paz'. La declaración del foro de soberanía alimentaria llevado a cabo en Nyéléni, Selingué, Mali pronunciada en el año 2007 define la soberanía alimentaria como,

El derecho de los pueblos a alimentos nutritivos y culturalmente adecuados, accesibles, producidos de forma sostenible y ecológica, y su derecho a decidir su propio sistema alimentario y productivo. Esto pone a aquellos que producen, distribuyen y consumen alimentos en el corazón de los sistemas y políticas alimentarias, por encima de las exigencias de los mercados y de las empresas. Defiende los intereses de, e incluye a, las futuras generaciones. Nos ofrece una estrategia para resistir y desmantelar el comercio libre y corporativo y el régimen alimentario actual, y para encauzar los sistemas alimentarios, agrícolas, pastoriles y de pesca para que pasen a estar gestionados por los productores y productoras locales.

De la definición se pueden hacer notar tres asuntos preeminentes. Primero, proponer la soberanía alimentaria como un derecho, segundo, el lugar del productor, y tercero, entender la soberanía alimentaria como una estrategia y acto de resistencia, esto es, como una apuesta política. El primer aspecto se presenta como un reclamo de la sociedad, en este caso, del conjunto de organizaciones, colectivos y líderes que hicieron parte del foro referenciado, en el que se establece una relación directa entre la soberanía alimentaria y la dignidad humana, a la vez que configuran en un discurso jurídico una reflexión en la que un tipo específico de relación con el cuerpo - en este caso a través de la alimentación- que se posiciona como condición fundamental para la realización humana, poniendo de presente el sentido cultural de las comunidades. El derecho se plantea en dos direcciones, por un lado, en la posibilidad de consumir alimentos nutritivos y culturalmente adecuados, y de otro lado, en la capacidad y autonomía respecto al sistema de alimentación y de producción de alimentos, de donde el sentido del derecho se puede entender a partir de contenidos médicos, políticos y culturales. 
En cuanto al lugar del productor se destaca la necesidad de empoderamiento de aquellos en la definición y capacidad de decisión sobre el sistema productivo y alimentario, así como la afirmación de su lugar dentro de la sociedad en general, que implica el reconocimiento del campesinado, del trabajador del campo, no sólo como productor de alimentos, sino sobre todo, como sujeto político esencialmente constitutivo del orden social. El productor de alimentos así mismo, es el que se enfrenta ante las contradicciones propias de la producción en general así como a las alternativas y condiciones para producir alimentos. En concreto estamos ante decisiones que afectan al conglomerado de consumidores y que tienen que ver con el tipo de insumos empleados, que varían entre químicos y orgánicos, la selección de semillas, que pueden ser tradicionales o naturales y transgénicas, y otro tipo de decisiones que se relacionan más con la vocación de la tierra, la variedad y calidad de alimentos sembrados, etc. Si notamos de cerca estas cuestiones, es posible observar la estrecha relación entre productor y consumidor, ya sea porque quien consume produce, o porque quien produce lo hace para un consumidor, de donde, en últimas el productor decide qué oferta alimentaria poner en el mercado para el consumidor. Por esta capacidad de decisión, la soberanía alimentaria especifica que se trata de alimentos nutritivos y culturalmente adecuados, lo que marca un acento de localidad a la propuesta.

Como acto de resistencia, la soberanía alimentaria se apone al monopolio trasnacional de alimentos y a las políticas agrícolas y alimentarias impuestas desde lugares ajenos a los propios pueblos, Estados o conglomerados, quienes son, en calidad de existencia, quienes deberían definir las políticas señaladas atendiendo a sus patrones culturales y sus conocimientos agrícolas. Este asunto es donde cobra mayor sentido político en términos internacionales el concepto de soberanía, puesto que aboga por la potestad de la comunidad política en la autodeterminación de las políticas que conciernen a la alimentación de su corpus social, en detrimento de la injerencia de otras instancias. En este sentido, cada comunidad política debe encaminar esfuerzo a la organización y participación para decidir qué alimentos producir, cómo producirlo y con qué herramientas técnicas, políticas, de comercio, etc., sobre la base de un objetivo local, esto es, producir para satisfacer las necesidades alimentarias a nivel local como condición básica de la producción agrícola. De ahí que la soberanía alimentaria sea un potenciador de la democracia participativa y la inclusión de sectores históricamente excluidos del sistema político. 
La organización internacional Vía Campesina (2003), promotora del debate y de acciones de en torno a la soberanía alimentaria, afirma que dentro de dicha apuesta están incluidos los siguientes puntos:

- Priorizar la producción agrícola local para alimentar a la población, el acceso de los/as campesinos/as y de los sin tierra a la tierra, al agua, a las semillas y al crédito. De ahí la necesidad de reformas agrarias, de la lucha contra los OGM (Organismos Genéticamente modificados), para el libre acceso a las semillas, y de mantener el agua en su calidad de bien público que se reparta de una forma sostenible.

- El derecho de los campesinos a producir alimentos y el derecho de los consumidores a poder decidir lo que quieren consumir y, como y quien se lo produce.

- El derecho de los Países a protegerse de las importaciones agrícolas y alimentarias demasiado baratas.

- Unos precios agrícolas ligados a los costes de producción: es posible siempre que los Países o las Uniones tengan el derecho de gravar con impuestos las importaciones demasiado baratas, que se comprometan a favor de una producción campesina sostenible y que controlen la producción en el mercado interior para evitar unos excedentes estructurales.

- La participación de los pueblos en la definición de política agraria.

- El reconocimiento de los derechos de los campesinos que desempeñan un papel esencial en la producción agrícola y en la alimentación.

Estos puntos se configuran como una apuesta política de organización social amplia que busca fortalecer la producción agrícola de cada comunidad política, rescatando principios como la soberanía, la participación, la protección y defensa de las economías propias y locales, que se enraízan en problemáticas que en medio de la economía neoliberal globalizada se agudizan, tales como: el deterioro de algunas economías débiles ante tratados de libre comercio, la producción de alimentos genéticamente modificados, el nacimiento de monopolios de semillas tratadas genéticamente, las relaciones comerciales asimétricas de alimentos, la injerencia de organismos trasnacionales en la política de países dependientes, el deterioro de la calidad de vida y las 
condiciones laborales de campesinos y campesinas, la acelerada concentración de la tierra a costa del desplazamiento forzado, entre otras relacionadas principalmente con las posibilidades de acceso a la tierra y a recursos naturales como el agua. La soberanía alimentaria pretende acercar al campesino a la política y abrir los escenarios públicos a la ciudadanía, que en este caso se pueden identificar como productores y consumidores de alimentos, teniendo a su vez presentes a las generaciones futuras.

El tercer aspecto a señalar, dentro de la problemática en torno a la tierra y al territorio, es la propuesta de protección de los derechos de los pueblos indígenas y las comunidades afrodescendientes sobre el territorio. Este un elemento fundamental para pensar el problema de la tierra en clave de reconciliación, en la medida en que las víctimas históricas del despojo, del desarraigo y la desterritorialización han sido los indígenas y las comunidades negras desde los tiempos de la Conquista. Por lo tanto, el proceso de paz y la comunidad política en general debe pensarse las múltiples afectaciones sufridas por dichos pueblos, y entrar en un diálogo intercultural en el que se reconozcan los conocimientos, las memorias y las cosmovisiones que den cuentan del sentido de la tierra y el territorio para vislumbrar en conjunto medidas de reparación, de restitución de tierras y de protección del territorio. Para los pueblos originarios, el territorio es la base esencial de la cultura, hasta el punto de afirmar que sin territorio no se es indígena, pues es en el territorio en donde es posible desplegar los saberes y prácticas propias de cada cultura, y de donde se extrae la fuerza vital para conservar la memoria y proyectar como comunidad. Hay que tener en cuenta que,

Pese a los innegables logros que los pueblos indígenas han tenido en el reconocimiento legal de sus derechos, las realidades de la guerra, de la exclusión social y de la imposición del modelo de desarrollo occidental han impedido que las comunidades gocen plenamente de estos derechos, en particular de aquellos que buscan asegurar la inmunidad de sus territorios frente a todo tipo de intervenciones externas. (Herreño, 2004, p.271)

Para el logro de la paz en Colombia se hace necesario asumir una postura humana y política de carácter intercultural y plurinacional, que surja de la conciencia de la diversidad cultural del país y del reconocimiento de los derechos de los pueblos indígenas y de las comunidades negras, sobre todo en lo que se refiere directamente al territorio, llegando al punto de señalar el territorio 
como un derecho humano y colectivo fundamental. En este sentido, derechos como la consulta previa deben ser asumidos estrictamente como condiciones garantes del derecho al territorio, al ejercerse desde un carácter plenamente decisorio y no meramente consultivo.

Predomina en la tradición colombiana el desconocimiento o bien, el abuso político sobre el campesinado en el país. Buscar la garantía de los derechos a las comunidades campesinas por parte del Estado, ha sido una bandera del movimiento campesino en los últimos años debido al recrudecimiento de la violencia y la injerencia destructiva por medio de políticas de gobierno que han afectado la economía y culturas campesinas. Un ejemplo de este comportamiento último es la política nacional de fumigación contemplada en la estrategia antinarcóticos del Plan Colombia ${ }^{4}$. Los efectos de esta política son el deterior del medio ambiente, la fragmentación de la vida campesina, el desplazamiento forzado, a causa del daño causado en la tierra y los cultivos los químicos con los que se pretende acabar la hoja de coca fumigando. Si esto es así, ¿qué hacer? Las organizaciones campesinas han resistido el embate de políticas nocivas para sus intereses y condiciones de vida, y desde allí han lograr tejer una serie de propuestas que se estructuran en comunidades en defensa del territorio y los derechos del campesinado.

Será entonces un propósito importante analizar cuáles deben las relaciones entre el Estado colombiano y los campesinos en Colombia. ¿Por qué? Porque el conflicto armado se origina precisamente en la ruptura violenta y el enfrentamiento radical entre campesinos y políticos a mediados del siglo XX. La consolidación del Estado como consolidación territorial no se da entre otras razones, porque el propósito de la élite política no versaba tanto sobre la conquista creciente del territorio, sino más bien consistía en la definición de la estructura y autoridad de las localidades conquistadas políticamente con los procesos independentistas. Pero en el siglo XX y propiamente por la llegada de distintos tipos de empresas extranjeras, la mirada se posa sobre nuevos terrenos para la concesión, en medio de donde se genera un conflicto por la tierra entre hacendados, campesinos, indígenas y gobernantes. Luego se incrementa el desplazamiento forzado y la estructura del país se modifica significativamente. Y en este movimiento social se

\footnotetext{
4 "Las fumigaciones han convertido el territorio colombiano en un gran campo de experimentación de agentes químicos, mucho antes incluso del inicio del Plan Colombia. Desde 1978 se ha estado ensayando sucesivamente con diferentes fórmulas: Paraquat, Triclopyr, Tebuthiuron, Imazapyr y Hexaxinona. Su éxito, sin embargo, fue escaso, por lo cual desde 1986 comenzó a utilizarse el herbicida glifosato de la transnacional norteamericana Monsanto". http://www.grain.org/es/article/entries/1020-las-fumigaciones-del-plan-colombia.
} 
genera un salto cualitativo a nivel político organizativo, donde se configuran grupos de víctimas del desplazamiento forzado y la violencia política que buscan el respeto de los derechos humanos y la permanencia en sus territorios. Son algunas de estas organizaciones las que hoy buscan establecer una relación con las distintas instancias y funciones de la administración pública y los niveles de gobierno. Se podrían proponer entonces escenarios de encuentro entre las organizaciones campesinas y las instancias de gobierno para evaluar la relación entre ambas y definir rutas de acción encaminadas al desarrollo de políticas agrarias y campesinas que beneficien al campesino.

Como un ejemplo de organización en esta vía, se encuentran las Zonas de Reserva Campesina (ZRC) que son una propuesta alternativa de desarrollo rural, basado en las condiciones ambientales y productivas de las regiones, la conservación de la tradición cultural, la interculturalidad, las prácticas del arraigo y los encuentros políticos guiados hacia un mismo fin, en orientación al mejoramiento de la calidad de vida de los campesinos, a través de un desarrollo endógeno, fruto de la combinación entre los saberes campesinos, los conocimientos técnicos y la aplicación de tecnologías apropiadas. Sus prácticas están orientadas hacia la conservación del medio ambiente, el uso productivo de la tierra, el trabajo colectivo, y la organización política de las comunidades. De este modo, el desarrollo agrario en las ZRC se orienta por un plan de desarrollo sostenible elaborado en las comunidades, a través de metodologías participativas, de acuerdo a un esquema de preguntas y datos que arrojan ideas de construcción de proyectos que beneficien a las poblaciones y que estas mismas definen como prioritarias y consecuentes en vía de solución a sus problemáticas.

El programa de las ZRC busca promover el acceso a la tierra, la legalización y titulación de los predios a campesinos y el goce efectivo del derecho a la tierra. Y en este objetico, la demanda por el derecho a la tierra implica el accionar del Estado de Derecho como responsable por la garantía de los derechos humanos y la interlocución participativa con las comunidades. En este sentido, la vía de reclamación se establece sobre los términos legales de ordenamiento del territorio. Se trata también de que los poseedores de tierra habiten el lugar donde están y puedan conservar ciertas características y proyectos propios, de modo que las ZRC se han convertido en una apuesta campesina de resistencia cultural y acción desde la autonomía y el autogobierno. 
Las ZRC, son una figura de ordenamiento territorial contemplada en la ley 160 de 1994, cuyo objetivo, entre otros, es promover y consolidar la paz, a través de mecanismos encaminados a lograr la justicia social, la democracia participativa y el bienestar de la población campesina. De otro lado, se establece que la ley buscará "Regular la ocupación y aprovechamiento de las tierras baldías de la Nación, dando preferencia en su adjudicación a los campesinos de escasos recursos, y establecer zonas de reserva campesina para el fomento de la pequeña propiedad rural, con sujeción a las políticas de conservación del medio ambiente y los recursos naturales renovables y a los criterios de ordenamiento territorial y de la propiedad rural que se señales".

El cumplimento de estos principios se puede corresponder con un proceso de redistribución de la tierra y la apertura de escenarios decisorios como las asambleas, las corporaciones, y la posibilidad de determinar el uso del territorio, esto es, la forma de vida campesina, para desarrollar propuestas como la soberanía alimentaria en tanto que propuesta de una forma de ordenar el territorio. Para ello es fundamental la educación para la paz que abre el espectro de la pregunta por la definición del lugar de la pedagogía y la educación en los procesos de organización social que se correspondan con iniciativas de paz y promoción de los derechos humanos.

Democracia y participación política. Se podrían establecer tres bloques sobre el tema de participación política y reconciliación que si bien son estrictamente relacionables entre ellos mismos, se puede asumir políticamente de forma diferenciada. Estos son, democracia, descriminalización y desestigmatización de la protesta social y de los movimientos sociales, y finalmente participación política de excombatientes.

El sentido de la democracia es la participación de la mayoría en la reflexión y decisión de los asuntos públicos que corresponde asumir a la comunidad política, buscando el bienestar y la felicidad de sus miembros. A pesar de tal sentido, la práctica de la democracia representativa ha definido cierto tamaño a la participación política limitándola a un enfoque electoral que no tiene muy claras las reglas del funcionamiento político, y en donde uno de los efectos de este comportamiento en el sistema político ha sido la hermeticidad y el cierre de este a nuevos 
agentes políticos y actores sociales que no necesariamente identifican la política con las elecciones.

La historia de la democracia representativa es la historia de la apropiación de la democracia popular por las clases propietarias, originariamente partidarias de un régimen constitucional favorable a los intereses de la economía capitalista, con derechos civiles y políticos restringidos a las minorías acaudaladas, con garantías para la iniciativa privada, sin redistribución de riqueza y sin derechos sociales. (Aguiló, 2013, p.1)

Este cierre del espectro político en términos institucionales y de cooptación del poder político, fue el escenario de la emergencia de poderes y liderazgos locales que empiezan a ser parte de la política nacional y del debate público por acciones que logran un impacto que capta la atención de la oficialidad. En consecuencia, el movimiento de la constitución de la persona en sujeto político influye en el sistema político provocando cambios en su interior, como por ejemplo, la dinámica de la democracia que en último término llevaría a la cuestión por el tipo de política que se está gestando en el país. Entonces pensar la paz en Colombia implica repensar la democracia en términos históricos y normativos, para develar cómo ha sido el comportamiento político de instituciones, actores y sectores sociales y de otro lado, proponer cuáles deben ser las reglas de juego democrático para el posconflicto y la reconciliación, teniendo en cuenta que una de las causas del conflicto armado ha sido el hermetismo y monopolio político de las élites tradicionalmente constituidas que han negado por vía jurídica y por vía militar el acceso de otras fuerzas para la dirección y la toma de decisiones políticas en el ámbito nacional de lo público.

Para recuperar el ejercicio de la soberanía popular es preciso tomar conciencia del reduccionismo del pensamiento democrático-liberal naturalizado y reaprender la democracia desde otras perspectivas. (...) Construir mejores formas de articulación y decisión política exige desaprender la monocultura de la democracia liberal, que reproduce la dominación de las élites y empobrece [otros] horizontes de experiencia democrática. El desaprendizaje de esta monocultura permitiría valorar prácticas invisibilizadas por los dictámenes canónicos... (Aguiló, 2013, p.2)

Cuáles son esas otras perspectivas de la democracia. La democracia directa se soporta sobre el principio político por excelencia de la participación y el acuerdo de todos los miembros sobre los 
asuntos a discutir. En este sentido, la participación implica el principio de información, así como la capacidad política para decidir, para gobernar. De donde la democracia directa se diferencia de la democracia representativa porque en la primera el poder de decisión se ejerce en primera persona, mientras que en la segunda el poder se delega en instituciones y políticos que ejercen la representación del poder político. La democracia directa faculta de antemano al ciudadano a ser parte constitutiva y decisoria de la comunidad política. En este sentido, el ciudadano es también gobernante y dirige el desarrollo de la política y la conducción de asuntos que se logran como públicos. Este poder se logra en lo local, se circunscribe inicialmente en ámbitos locales de gobierno, de jurisdicción, de cierta delimitación territorial. Son líderes, comunidades, comités, fulanos, los que componen los órganos de decisión. La democracia directa es una forma de diálogo o de violencia intercultural que supone el reto de ofrecerse como un espacio para el encuentro.

Del modo que la organización social se desplegará en unos ciertos niveles de democracia y de órganos, instituciones o espacios para la toma de decisiones que deberán corresponder con un cierto grado de cercanía entre el sujeto y el territorio. La democracia directa es territorial, se circunscribe en localidades organizadas que se proyectan espacios de gobierno diversos e interrelacionados. Se trata de establecer una relación directa entre quien decide y quien se ve afectado por las decisiones, cerrando el espacio de la intermediación política que se entiende como representación. La democracia directa asume que la persona es sujeto político y está en la capacidad de participar en la propuesta, discusión y toma de decisiones políticas que encauzan el rumbo de la comunidad, la sociedad, etc., significando a su vez que la representación no es el sentido de la política en la medida en que los intereses, percepciones y comprensiones de cada sujeto son irrepresentables. Por lo tanto, el nivel de participación es máximo.

De otro lado, en términos de la construcción de esa democracia directa, se convierte en un imperativo el respeto y la expresión de la ciudadanía en la protesta social como mecanismo de comunicación y reclamación ante el Estado. La criminalización de la protesta social ha sido el modus operandi originante de las fuerzas armadas del Estado en contra de grupos y sectores organizados de la población civil. Estrategia que ha afectado la participación política y el desarrollo democrático de la nación. Por lo que la descriminalización de la protesta social y sobre 
todo la desestigmatización de la misma se convierten en una necesidad democrática para la construcción de paz. La modificación de las Fuerzas Armadas del Estado debe orientar primeramente hacia la formación ciudadana militar de los derechos humanos y el derecho internacional humanitario, como normas orientadoras de su quehacer. Si se conserva e esquema del Estado como forma de organización, habrá que preguntarse cuál va a ser la orientación para las Fuerzas Armadas.

Ese es el reto de la democracia en un régimen de Estado de Derecho, que debe garantizar el derecho a la protesta, a la libre asociación y a la disidencia política y por esto, debe circunscribirse hasta un grado de libertad política de la ciudadanía, que se advierte, es participativa. Lo que ocurre es que las prácticas que se reclaman como derechos, son el sustento de la norma, es decir, el ciudadano accede al Estado cuando logra establecer un diálogo con él, pero el derecho se exige con fuerza de exigencia: La conquista de derechos. Permitir y garantizar la participación de la ciudadanía en la construcción de la comunidad política.

Si se presenta un cambio de estrategia para la orientación del comportamiento del Estado frente a poderes emergentes, puede pensarse en el recrudecimiento del accionar de las fuerzas armadas que al decirse contrainsurgentes se va sobre líderes, movimientos, organizaciones, eliminando la oposición con guerra. Este escenario de guerra en Colombia, que muchos no conocen bien.

Deben ocurrir entonces dos cambios estructurales del sistema político: la participación política de los excombatientes de las Farc-Ep y el cambio de la orientación de la política estatal sobre todo en lo concerniente a la economía del país. Condiciones que se dan por el trasegar de la organización social y el ejercicio de la soberanía popular. Lo mínimo que se esperaría en un acuerdo de paz de esta magnitud, es que quienes han hecho respaldados con las armas, quieran y puedan hoy hacerlo respaldados en el Derecho y la justicia nacional. Y de otro lado, que las reivindicaciones de múltiples sectores de la población que se han visto recogidas en la lucha guerrillera, se vean reflejadas en acuerdos orientados al cambio de las condiciones de vida y la administración del mercado. 
Justicia transicional y derechos de las víctimas. Los principios de la justicia transicional se sitúan en un contexto particular de la historia de un Estado en el que se evidencia un cambio de Régimen político o bien de Sistema político que supone la transición hacia un estadio liberal democrático. Se aplica pues en contextos de transición la intervención del Derecho en el ordenamiento social que trasgrede los parámetros de la justicia penal. Se entiende desde el anhelo de la paz, aplicar un ordenamiento jurídico alternativo para enjuiciar y asumir jurídicamente un proceso de paz. De ahí que se establezcan penas alternativas al derecho penal para los crímenes de lesa humanidad, entre otros, que se entienden en un escenario de guerra total. La superación de la confrontación puede depender de un tratamiento especial en el lugar de la contienda y unas condiciones jurídicas que lo protejan. La confianza jurídica se logra por acuerdos políticos entre los negociadores.

En la confección del derecho para hacer justicia transicional impera la decisión política de negociar, transar o pactar con el adversario; así el derecho pasa a convertirse en un instrumento de negociación, hay un acomodamiento del derecho a la coyuntura de negociación y desmovilización. (Ramos, 2014, p.1)

También surgen otras demandas como lo son los derechos de las víctimas. El derecho a la verdad, saber qué pasó, cómo pasó, por qué la vida fue así, relatos que aclaran la memoria, recomponen la historia, hacen parte de tu pasado. El derecho a la justicia que resulta ser el más complejo en la medida en que todos reclaman no a la impunidad, pero padecen injusticias distintas, variadas, cruzadas, inmesurables. Cómo es la justicia de la justicia transicional. El derecho a la reparación que implica propender hacia la restitución del derecho de la víctima y las condiciones antes del hecho de violencia. Un derecho que por su naturaleza no puede garantizarse, el derecho a la no repetición. Nota. Todos los pactos de paz en Colombia han sido firmados en medio del conflicto armado. El Estado siempre ha estado en guerra con grupos armados que emergen como alternativa de poder. El Estado debe garantizar la no repetición de los hechos de violencia.

La justicia transicional se orienta hacia el logro de acuerdos para el tratamiento de la paz y la promoción de la reconciliación nacional. La justicia transicional implica así mismo abrirle un 
expediente al conflicto armado, re hacer su historia, relatas muchos nuevos hechos. Los proyectos de memoria histórica abren horizontes de posibilidades y saberes del conflicto armado que permiten claridad y procesos de reparación. Compartir memorias, entrecruzar historias, hablar de la propia historia y tramitar los efectos de la violencia. El tema de los derechos de las víctimas se convierte en un objeto de estudio común en la academia colombiana, el saber científico social se encarga de liderar los procesos gubernamentales para la defensa de los derechos de las víctimas.

Y, cual es el lugar de la víctima en un proceso de justicia transicional.

Documentar la violencia desde la memoria, privilegiando las voces de las víctimas, nos permitió no sólo esclarecer hechos, identificar los motivos, intereses e intenciones de quienes ordenaron y perpetraron el horror, sino también acercarnos a la comprensión de las experiencias de las víctimas y reconocer los daños y los impactos que estas han experimentados individual y colectivamente. (Grupo de Memoria Histórica, 2013, p.25)

El territorio constantemente en disputa, debe ser uno de los aspectos centrales de las prácticas de transición. En Colombia debe orientarse la política agraria hacia tres asuntos centrales: la reforma agraria, la restitución de tierras, y la protección de los territorios. Distribuir la tierra, devolver la tierra despojada, y defender el derecho a habitar un territorio. Ya existen una serie de políticas que ordenan el territorio y la protección de la pequeña propiedad como lo son la figura del resguardo indígena, de los territorios colectivos, y de las zonas de reserva campesina. Sin embargo, estas figuras, por las condiciones de desplazamiento, tenencia de la tierra y seguridad jurídica, no logran satisfacer los conflictos que se ocasionan por problemas por la tierra. Es necesario entonces generar condiciones de estabilidad y permanencia en la tierra, así como considerar la ampliación del espacio ocupado. Fortalecer, ampliar y crear resguardos indígenas, considerando la organización del territorio desde a autonomía de la comunidad indígena. La ley debe considerar el autogobierno de los pueblos indígenas como un derecho innegable. Lo cual apunta en la teoría del derecho por la cuestión del pluralismo jurídico y las medidas de la justicia.

Distintas medidas pueden ser tomadas para abordar el problema del desplazamiento forzado, el despojo de tierras, y la violación de derecho humanos en medio del conflicto armado. El 
problema de la orientación de las medidas de reparación es que no todas apuntan a la satisfacción de los derechos de las víctimas, sino que usan el discurso de la restitución para fortalecer proyectos productivos como en el caso de la agroindustria. En estos casos, e derecho a la restitución es condicionado a unos ciertos parámetros: uno de ellos, que el predio a ser restituido no esté dedicado a la agroindustria (Artículo 99, de la Ley 1448 de 2011- Ley de víctimas y restitución de tierras). Quien oriente a política de reparación de víctimas de despojo de tierras, determinará la orientación de la ley, del delito, del nivel de satisfacción, de enfoque de derechos. Por eso se considera que la participación de las víctimas en los procesos de diseño de las políticas es fundamental, en la medida en que se recojan las propuestas y están sean vinculantes, decisorias. La consideración de las víctimas permite el acercamiento a la experiencia del despojo y a lo que se podría esperar de un proceso de reparación.

La reparación supone antes un proceso de memoria, de rememoración de lo que ha pasado. Pensar en la forma de reparar un daño, de intentar restituir una serie de condiciones que se vieron trastocadas por los hechos de violencia, supone la recordación de pasados, de historias, de recuerdos y memoria, que permitan establecer una medición sobre los daños sufridos y medidas de reparación. Por eso la memoria constituye una praxis central del proceso de posconflicto, porque una vez se ha asumido a existencia y profundidad de un conflicto de tales dimensiones, la verdad empieza a ser una necesidad. Decir la verdad, saber la verdad, buscar la verdad. Catarsis, necesidad, curiosidad. Los jóvenes necesitan escuchar las memorias, pues entre los juegos cibernéticos y el colegio, se perdió la historia. Los viejos necesitan decirlas, pues su historia es el único legado que le deja a la humanidad. Y así la vida pende de la memoria, de las historias por ser contadas y las gentes que ansían de aquellas.

Es importante notar un suceso. Las reparaciones se vienen entendiendo como pagos, que realiza el Estado en atención a las víctimas, y que por lo tanto, si no hay presupuesto se pone en cuestión la reparación. La reparación en un proceso transicional y más específicamente en un proceso de negociación de la paz, debe orientarse desde la necesidad de modificar estructuras sobre las cuales se sustenta el orden del conflicto armado. No se trataría entonces exclusivamente de una cuestión de presupuesto como lo hacen ver algunos profesionales de la política fiscal colombiana, sino que sobre todo ese tipo de política debe ser cambiada, a la par que se orientan 
cambios institucionales que se proyecten como escenarios participativos en la reconstrucción social. Aunque el conflicto armado no sea padecido directamente por todos los colombianos, sus causas si lo son. Por lo tanto, a reparación debe ser colectiva, comunitaria, nacional.

La restitución de tierras y el retorno de los campesinos a sus tierras es una prioridad para la transformación de la estructura y tenencia de la tierra y la orientación del agro colombiano. Se propone que se utilicen figuras de organización que permitan el despliegue autónomo de las comunidades. Del mismo modo, la consagración de titularidad, pertenencia y autogobierno a territorios ancestrales indígenas a comunidades que hoy los reclaman. La consideración y estudio de los casos de títulos coloniales que hoy amparan la pertenencia de comunidades afro en territorios que colindan con resguardos indígenas y con proyectos de zonas de reserva campesina. Se debe comprender una política que exprese las consideraciones y acuerdos sobre ordenamiento territorial de las zonas en las que viven comunidades campesinas, indígenas y afro que se respaldan en normas que regulan la propiedad de la tierra, para proteger y ampliar sus territorios. Atender un conflicto sobre el territorio que se está presentando debe estar contemplado en las decisiones sobre reparación en justicia transicional.

\subsection{Educación para la paz}

La educación para la paz comporta dos cuestiones primarias que son precisos abordar. Partimos de la generalidad que identifica la educación con las instituciones educativas y el devenir de los colegios y las academias en la implantación de una metodología de enseñanza que impacta claro está, tanto la mente como el cuerpo del escolar. No es suficiente pensar el modo de escolaridad, sino sobre todo, repensar qué es la educación. La educación es el continuo vivir de circunstancias de las que se aprende y se logra un entendimiento.

Y ahora bien, qué es la paz, qué es paz. La paz es sensación de tranquilidad y confianza de estar vivo. Es el reconocimiento de la vida como forma de ser. La paz en sociedad supone el cumplimiento de acuerdos que lleven al logro del bienestar del individuo o de la comunidad. La paz se asume como un proyecto colectivo que implica desde siempre el carácter político de la 
comunidad. En la medida en que se definen territorios, se establecen jerarquías, las nociones en torno a la distribución de bienes cambia, etc. La paz puede pensarse desde un ámbito personal, espiritual, y también en una condición social de bienestar y dignidad.

Entonces puede ser que la educación para la paz es la educación de la memoria, el aprendizaje está en lo que guardan los abuelos, en la historia del pasado. Saber qué está pasando. Por qué las cosas pasan como están pasando, cuál es nuestra historia. Es que si va a vivir con el enemigo por lo menos se deben saber sus secretos más oscuros. Entender la historia de la economía del país, de la política. Conjurar las historias y armar la compleja y sensible imagen del conflicto armado. Porque en últimas de lo que más tenemos que aprender es de nuestro pasado. Téngase en cuenta, que lo sepamos no quiere decir que lo entendamos, necesariamente.

La cultura, el arte, el folcklore, la fiesta, la celebración, los rituales de cada comunidad como forma de expresar, como pedagógica de la vida social del posconflicto, del duelo, de una especie de síntesis social.

El arte es la expresión más alta del hombre o de la humanidad, en el sentido en que uno encuentre para qué estamos en este mundo, para qué vivimos. Porque uno ve que en la sociedad se esfuerza, todo el mundo corre y corre y en último momento termina vacío. Pero el arte le da esos elementos, para que uno se encuentre consigo mismo y se sitúe al nivel de todos los seres de la madre Tierra... Lograr que la gente a través del arte se sensibilice en ese mundo en que los seres humanos no somos los únicos dueños del universo sino que también los pájaros, las aves, los peces, también tienen su lenguaje y son nuestros hermanos.; entonces en ese momento estaremos ganando mucho, yo creo que ese es el afán del arte. (Chikangana, 2014, p.152)

Una educación que permita el conocimiento del sí mismo, saber de sí, de su entorno, de las formas posibles de relación e interacción social, que abre el espectro de posibilidades para unas prácticas educativas diferentes, fundamentadas en el amparo de las necesidades del ser humano, de las comunidades. Una educación estética, de qué tipo de estética, estética de la comunidad, del dolor, del perdón, de la celebración, la belleza y el color de pueblo. "Las palabras son vehículos para traer algo a la existencia: una visión de la paz, una visión de conexión, una visión 
de contar una historia de quienes somos, lo que hemos hecho, lo que hemos sido, adónde vamos" (Harjo, 2014, p.87).

El arte como conjuro, como expresión del símbolo que se logra de la relación entre cuerpo, memoria, festejo y celebración. Qué pasa si se indaga por la memoria del cuerpo de cierta mujer que habitaba cierto territorio. Qué memorias pueden emerger ahí, qué sensaciones generaría su relato. El arte es emergencia. Lo es también la memoria. La memoria es una forma de arte. El relato, el cuento, la historia.

Es que cuantas historias tiene la gente. Vemos cómo la historia nacional es la magnificación de la historia de unas personas. La memoria histórica reconstruye el relato desde otras historias no narradas en las páginas oficiales. Eso compete así mismo a una propuesta educativa, que se piense la historia del país, la historia bizarra, macabra, psicótica de la política, de la económica. Pero también la historia de lucha, de organización de orientación de la vida hacia la reivindicación de derechos, de condiciones para una mejor calidad de vida, para vivir en paz. La historia de dolores pasados, que claro, como memoria, perdura.

Entonces aparecen nuevos paradigmas, nuevos saberes, nuevos que realmente son ancestrales. Formas distintas de aprender, de educar-nos.

\section{Escucha la noche hijo mío}

y no me preguntes

que la noche es celosa de tantas traiciones

de cada dolor que se esconde en cada rincón

de la tierra.

Escucha el rumor del cielo hijo mío

ahí están nuestros muertos

escucha el canto del grillo

es un niño en la oscuridad

escucha el grito ahogado de una mujer

los dolores de piel, el metal, y 
la bravura del mar

escucha la lluvia

que cierra los párpados

escucha el silencio hijo mío

ahí está la verdadera palabra.

(Chikangana, 2014, p.154)

La educación intercultural supone en principio reconocer la existencia de interculturalidad en la sociedad, y respetarla.

Los pueblos indígenas somos sociedades y sujetos interculturales. Creo que la base de que los pueblos indígenas persistan hoy en día, es justamente eso. Que hemos sabido mantener nuestra cultura, pero también hemos sabido retomar de otras tradiciones, de otras instituciones, de otras culturas, elementos que nos ayudan a no perder eso que somos. (Regino, 2014, p.134)

Ahora bien, orientar esfuerzos para investigar cuáles han sido las prácticas de memoria de que se han valido las víctimas del conflicto armado para restablecer verdades, ocupar un lugar en lo local y en la opinión pública sobre su experiencia como víctimas, como sobrevivientes. Revisar las narrativas y sobre todo las prácticas de organización de distintos colectivos, grupos sociales en torno a las reivindicaciones sobre los derechos de las víctimas se erige como un ejercicio reflexivo que buscaría ahondar en las posibilidades desconocidas por la historia oficial del país, en los enunciados locales que no han tenido cabida en la opinión pública pero que significan una parte material constitutiva del devenir histórico nacional.

Y frente a la histórica enseñanza escolar, qué decir, que lo diga Zuleta (2010), autor de lo que sigue,

La educación, tal como ella existe en la actualidad, reprime el pensamiento, trasmite datos, conocimientos, saberes y resultados de procesos que otros pensaron, pero no enseña ni permite pensar. A ello se debe que el estudiante adquiere un respeto por el maestro y la educación que procede simplemente de la intimidación. (p.11) 
Propone Zuleta (2010) que la educación reprime el pensamiento, no permite pensar, no enseña ni deja pensar. Repetir, aprender, memorizar. Esa es la trasmisión de datos, procedimientos, resultados que se saben pero no entienden, o no se piensan, se automatizan. Y refuerza con una denuncia radical: el respeto que el estudiante siente por el maestro proviene de la intimidación que le causa no saber cómo interlocutar con el maestro. Incapacidad cognitiva, desigualdad social. El maestro tiene el saber, enseña la técnica y evalúa el desempeño. Y,

Lo que se enseña no tiene muchas veces relación alguna con el pensamiento del estudiante, en otros términos, no se lo respeta, ni se lo reconoce corno un pensador y el niño es un pensador. La definición de Freud hay que repetirla una y mil veces: el niño es un investigador; si lo reprimen y lo ponen a repetir y a aprender cosas que no le interesan y que él no puede investigar, a eso no se puede llamar educar. (Zuleta, 2010, p.11-12)

Contundente el sentido de la educación que propone entre líneas Zuleta: educar tiene que ver con las posibilidades del pensamiento y su desarrollo en sociedad, y por tanto, tiene que ver con el reconocimiento de quien está ahí pensando. El imperativo epistemológico para reconocer la educación como proceso social crítico es el reconocimiento del sujeto pensante y la capacidad de diálogo entre saberes. Y dar el paso crítico que, en palabras de Freire (2005), se debe dar por la sencilla razón de que,

Hacemos... sin preguntarnos ni una sola vez por qué lo hicimos. Nos damos cuenta de qué hacemos pero no indagamos las razones por las que lo hacemos. Eso es lo que caracteriza nuestro operar en el mundo concreto de lo cotidiano. Actuamos en él con una serie de saberes que al haber sido aprendidos a lo largo de nuestra sociabilidad se convirtieron en hábitos automatizados. Y por actuar así, nuestra mente no se activa para la búsqueda de las razones de ser de los hechos. (p.115)

Entonces, el sentido de la educación crítica es la posibilidad y capacidad de reflexionar sobre lo que se hace, lo que la misma educación significa. De cómo se dan los procesos educativos, a qué margen se restringen, quiénes son los maestros, cuál es el lugar de la educación. Y pensar de qué manera el sistema de enseñanza escolar puede tramitar la crítica esecialista de Zuleta (2010). 
Además del problema de enseñar resultados, sin enseñar los procesos del conocimiento, existe un problema esencial: en la escuela se enseña sin filosofía y ese es el mayor desastre de la educación. Se enseña geografía sin filosofía, biología sin filosofía, historia sin filosofía, filosofía sin filosofía, etc. (p.15) 


\section{CONCLUSIONES}

En el recorrido de la reflexión filosófica en torno a la reconciliación en general y para el caso específico colombiano, fueron saliendo al paso distintas conclusiones, ideas y propuestas de las cuales se identifican las siguientes como las principales. Inicialmente, se puede afirmar que la reconciliación es un proceso deseado, posible y de construcción a largo plazo, y que como concepto resulta polisémico y comporta un significado multidimensional de lo humano y lo social que amerita ser abordado desde una postura de filosofía situada y socialmente útil y comprometida. De lo anterior se tiene que,

- Los enfoques y disciplinas desde los cuales se ha abordado el concepto de reconciliación, a saber, la teología, la filosofía, la ciencia política, el derecho y la sabiduría ancestral indígena, resultan insuficientes si se asumen aisladamente, pues cada uno no logra abarcar la complejidad y multidimensional ni del hombre, ni de la sociedad, ni de la Naturaleza y las distintas relaciones que se erigen entre estos. La reconciliación debe asumirse de manera integral, abordando la complejidad del proceso de reconciliación para generar medidas de satisfacción y el logro de una paz positiva duradera. Entonces, es preciso poner a dialogar las distintas disciplinas y avanzar en la recuperación de saberes y tradiciones silenciadas, así como propiciar el encuentro de las instituciones que pretenden aportar en la construcción de la reconciliación, con el fin de establecer acuerdos positivos para el proceso con elementos de fundamentación y análisis.

- La reconciliación como proceso transformado y transformador de la realidad, supone cambios estructurales en la sociedad, en la economía y en la política colombiana, que apunten al mejoramiento de la calidad de vida de sus habitantes, a la soberanía nacional y el ejercicio democrático de la política. Así mismo estos elementos se entienden en la reconstrucción del tejido social lograda por la reparación, sobre la base de la cualificación de las relaciones interpersonales basadas en la alteridad, la justicia, la reciprocidad y la solidaridad, componiendo posibilidades de una sociedad del perdón. 
- Para lograr la reconciliación en Colombia se propone la reflexión sobre la sociedad del perdón, en la que se asumen unos mínimos de justicia, una apuesta de la verdad y de una verdad que provenga en gran medida de la memoria colectiva. Así mismo, la reconciliación se asume bajo la premisa de la ética de la alteridad, del compromiso, la responsabilidad y la ontología para con el otro, con la otredad, asumiendo al ser humano como un ser sociable, de sociedad, de asociación, de tal forma que se comprenda un sentido antropológico y político de la alteridad. Se propone entonces la alteridad como campo de conocimiento, como quiebre epistemológico y como imperativo ético de la reconciliación siendo que toda definición y comprensión del yo incluye de antemano un otro.

- La reconciliación en Colombia puede lograrse paulatinamente a partir del crecimiento, reconocimiento y consolidación del movimiento social colombiano, de la suma de expresiones locales que expresa en su quehacer y en sus plataformas políticas la reconciliación, la paz y la justicia social. Es imprescindible tener en cuenta que a pesar de que los acuerdos de paz se firman a nivel nacional, los procesos de reconciliación y de posconflicto se construyen a nivel local.

- Dentro de los cambios estructurales que se proponen para avanzar en la construcción de una paz positiva y duradera se plantea: la distribución de la tierra, desde un sentido de reforma agraria integral, esto es, más para los que menos tienen, y menos para los que más tienen, con el acompañamiento de condiciones agrarias óptimas para la producción campesina; soberanía alimentaria, que consiste en el poder de decisión y ejecución de políticas agrarias encaminadas al fortalecimiento del mercado interno orientado a la producción de alimentos, que garantice el abastecimiento y calidad de los alimentos para los habitantes del territorio colombiano; la protección decidida y trasparente, bien sentida de los territorios indígenas, teniendo en cuenta que la ancestralidad de ciertos territorios se conserva en la memoria de las prácticas de las comunidades, y de allí el carácter esencial del respeto de la territorialidad, de la cultura, del existir de los pueblos; pensar y re-prensar los significados de la tierra, del territorio para orientar las políticas públicas de reparación, las leyes de ordenamiento territorial, la ley de desarrollo rural; el progresivo 
acceso a la tierra de los campesinos, de los trabajadores de la tierra, de los desplazados del campo, desde un enfoque de derechos, esto es, con la orientación de la dignidad, de la dignificación de la vida campesina.

- La educación para la paz propone una revisión de los principios de la educación popular, de la pedagogía de la liberación y de la filosofía latinoamericana, para rescatar de allí fundamentos pedagógicos y críticos para pensar la educación en Colombia. Se rescata el lugar del arte, de la festividad, de los rituales, de los lugares que hacen representativo un saber que se tramita en la cultura y posiblemente, en la comunidad. La educación para la paz debe pensarse los cimientos psíquicos y sociales de la convivencia pacífica, de la construcción de tejido social, de la emancipación y de la organización social democrática. Entendiendo la democracia como la capacidad del ser humano de hacer parte efectiva y reflexiva de su entorno social.

- Es necesario que dentro del sistema nacional de educación se promuevan e impartan cátedras de paz y democracia, con el fin de transformar las prácticas de aprendizaje hacia la sociabilidad pacífica y la construcción del perdón y la reconciliación nacional, teniendo como uno de sus fundamentos, la formación política para la orientación organizativa de los alumnos. Pensar la educación para la paz es así mismo pensar en una educación que responda a las problemáticas de la sociedad en su conjunto, pero sobre todo, a las necesidades del posconflicto y la satisfacción de necesidades de las poblaciones vulnerables del país. 


\section{REFERENCIAS BIBLIOGRÁFICAS}

\section{Libros}

Adorno, T. (2005). Dialéctica negativa- la jerga de la autenticidad. Madrid, España: Akal.

Arendt, H. (1997). ¿Qué es política?. Barcelona, España: Paidós.

_. (2003). La condición humana. Barcelona, España: Paidós.

Aristóteles. (2004). Ética nicomaquea. Bogotá, Colombia: Ediciones Universales.

_. (2005). El arte de la retórica. Buenos Aires, Argentina: Eudeba.

Benjamin, W. (1973). Tesis de filosofía de la historia. Madrid, España: Taurus.

Dussel, E. (2006). 20 tesis de política. Ciudad de México, México: Siglo XXI.

_. (2008). 1492 El encubrimiento del otro. La Paz, Bolivia: Biblioteca indígena.

Estermann, J. (1998). Filosofía andina: Estudio intercultural de la sabiduría autóctona andina. Quito, Ecuador: Abyayala.

Foucault, M. (2009). El gobierno de sí y de los otros. Ciudad de México, México: Fondo de Cultura Económica.

Freire, P. (2005). Cartas a quien pretende enseñar. Ciudad de México, México: Siglo XXI Editores.

Kelsen, H. (1992). ¿Qué es la justicia?. Barcelona, España: Ariel.

Lévinas, E. (2000). Ética e infinito. Madrid, España: Graficas Rógar. 
_. (2002). Algunas reflexiones sobre la filosofía del hitlerismo- El mal elemental. Buenos Aires, Argentina: Fondo de Cultura Económica.

Murray, J. (2007). El plan de salvación. Michigan, Estados Unidos: Libros Desafío.

Reyes Mate, M. (2003). Memoria de Auschwitz. Madrid, España: Editorial Trotta.

Reyes Mate, M. y Mardones, J. M. (Eds.). (2003). La ética ante las víctimas. Barcelona, España: Anthropos.

Reyes Mate, M. (2006). Contra lo políticamente correcto: política, memoria y justicia. Buenos Aires, Argentina: Altamira.

Tomás de Aquino. (1978). Tratado de justicia. Bogotá, Colombia: Universidad Santo Tomás.

Shreiter, R. J. (1998). Violencia y reconciliación. Misión y ministerio en un orden social en cambio. Santander, España: Sal Terrae.

Shreiter, R. J. (2000). El ministerio de la reconciliación. Espiritualidad y estrategias. Santander, España: Sal Terrae.

Uprimny, R. (2006). ¿Justicia transicional sin transición? Verdad, justicia y reparación para Colombia. Bogotá, Colombia: Antropos.

\section{Libros en versión electrónica}

Dussel, E. (1983). Praxis latinoamericana y filosofía de la liberación. Recuperado de http://www.ceapedi.com.ar/imagenes/biblioteca/libros/96.pdf.

Schmitt, C. (1932). El concepto de lo político. Recuperado de http://arditiesp.files.wordpress.com/2012/10/schmitt-carl-el-concepto-de-lo-policc81ticocompleto.pdf. 
Zuleta, E. (2010). Educación y democracia. Recuperado de http://www.omegalfa.es/downloadfile.php?file=libros/educacion-y-democracia.pdf.

\section{Capítulos de libros}

Scannone, J. C. (1984). Sabiduría popular y pensamiento especulativo. En: Varios autores. Sabiduría popular, símbolo y filosofía. Diálogo internacional en torno a una interpretación latinoamericana (pp. 51-90). Buenos Aires, Argentina: Guadalupe.

Tafalla, M. (2003). Recordar para no repetir: el nuevo imperativo categórico de T.W. Adorno. En: Mardones, J. M. y Reyes Mate, M. (Eds.), La ética ante las víctimas (pp. 126-154). Barcelona, España: Anthropos.

\section{Artículos de revista}

Chikangana, F. (2014). Fredy Chikangana. Colombia, Nación Yanacona. Prometeo, 32(98-99), 152-155.

Harjo, J. (2014). Joy Harjo. Estados Unidos, Nación Muskogee. Prometeo, 32(98-99), 87-91.

Regino, J.G. (2014). Juan Gregorio Regino. México, Nación Mazateca. Prometeo, 32(98-99), 134-138.

\section{Artículos de revista online}

Bueno Cipagauta, M. A. (2006). La reconciliación como un proceso socio-político. Aproximaciones teóricas. Reflexión política, 8(15), 64-78. Recuperado de http://revistas.unab.edu.co/index.php?journal=reflexion\&page=article\&op=view\&path $\%$ $5 \mathrm{~B} \% 5 \mathrm{D}=616 \&$ path $\% 5 \mathrm{~B} \% 5 \mathrm{D}=592$.

Derrida, J. (2000). Confesar - Lo imposible "Retornos", arrepentimiento y reconciliación. Isegoría (23), $17-43 . \quad$ Recuperado de http://isegoria.revistas.csic.es/index.php/isegoria/article/viewFile/534/534. 
Herreño Hernández, Á. L. (2004). Evolución política y legal del concepto de territorio ancestral indígena en Colombia. El otro derecho, (31-32), 247-272. Recuperado de http://ilsa.org.co:81/biblioteca/dwnlds/od/elotrdr031-32/elotrdr031-32-10.pdf.

Sobrino, J. (2003). El cristianismo y la reconciliación. Concilium, (303), 95-106. Recuperado de http://sedosmission.org/old/spa/sobrino_2.htm.

Teitel, R. G. (2003). Genealogía de la justicia transicional. Harvard Human Rights Journal, (16), 69-94.

Recuperado

de http://new.pensamientopenal.com.ar/01092009/derechoshumanos02.pdf.

\section{Artículos en la Web}

Aguiló, A. (2013, 18 al 24 de enero). (Des) aprender la democracia. Semanario Virtual Caja de Herramientas. Recuperado de http://www.viva.org.co/cajavirtual/svc0335/articulo14.html.

Beristain, C. M. (s.f.). Reconciliación luego de conflictos violentos: un marco teórico. Recuperado de http://www.idea.int/publications/vjr/upload/Reconciliaci\%C3\%B3n\%20luego\%20de\%20 conflictos\%20violentos\%20-\%20un\%20marco\%20te\%C3\%B3rico.pdf.

Comblin, J. (2001). Teología de la reconciliación. Recuperado de http://www.memoriayprofecia.com.pe/sites/default/files/REFLEX_COM.doc.

Estermann, J. (s.f.). La filosofía quechua. Recuperado de http://www.olimon.org/uan/12quechua-estermann.pdf.

Herrera, C. y Garrido, E. (s.f.). La reconciliación como programa político: propuesta de agenda gubernamental. Recuperado de http://www.ugr.es/ eirene/publicaciones/los_habitus_de_la_paz/habitus_8.pdf.

La Vía Campesina Movimiento Campesino Internacional. (2003, 16 de enero). Qué es la soberanía alimentaria. Recuperado de http://viacampesina.org/es/index.php/temasprincipales-mainmenu-27/soberanalimentary-comercio-mainmenu-38/314-que-es-lasoberania-alimentaria. 
Manwelo, P. SJ. (2009). El tema de la reconciliación en la filosofía política. Recuperado de http://www.sjweb.info/sjs/pjnew/PJShow.cfm?pubTextID=8414.

Ramos, A. (2014, 11 al 17 de julio). Justicia transicional. Semanario Virtual Caja de Herramientas. $\quad$ Recuperado http://www.viva.org.co/cajavirtual/svc0407/articulo03.html.

Revista Semana. Informe especial. Así es la Colombia rural. http://www.semana.com/especiales/pilares-tierra/asi-es-la-colombia-rural.html

Uprimny, R. y Saffon, M. P. (s.f.). Hacia una concepción democrática de la reconciliación. Recuperado de http://files.caminosparalareconciliacion.webnode.es/200000012b8c39b9bcf/Saffon_Uprimny_RECONCILIACION.pdf.

Vaticano. (s.f.). Catolicismo de la Iglesia Católica. Recuperado de http://www.vatican.va/archive/catechism_sp/p2s2c2a4_sp.html.

Zea, L. (1979). Negritud $e$ indigenismo. Recuperado de http://ru.ffyl.unam.mx:8080/jspui/bitstream/10391/3033/1/89_CCLat_1979_Zea.pdf.

\section{Informes}

Corte Interamericana de Derechos Humanos. (1995). Caso El Amparo sentencia de 18 de enero de 1995. Recuperado de https://www1.umn.edu/humanrts/iachr/!19elas.pdf.

Grupo de Memoria Histórica, Centro Nacional de Memoria Histórica. (2013). ¡Basta ya! Colombia: memorias de guerra y dignidad. Bogotá, Colombia.

Joinet, M. (1997). La cuestión de la impunidad de los autores de violaciones de los derechos humanos (civiles y políticos). Recuperado de http://www.derechos.org/nizkor/doc/joinete.html.

Observatorio de construcción de Paz. (2013). Cuadernos paz a la carta $N^{\circ}$ 4. Bogotá, Colombia: Universidad Jorge Tadeo Lozano. 